\author{
UNIVERSIDADE DE SÃO PAULO \\ FACULDADE DE ECONOMIA, ADMINISTRAÇÃO E CONTABILIDADE \\ DEPARTAMENTO DE ADMINISTRAÇÃO \\ PROGRAMA DE MESTRADO PROFISSIONAL EM EMPREENDEDORISMO
}

DAVI LASKANI HOFFMANN

Crescimento em Consultorias e Assessorias Empresariais:

fatores limitantes e impulsionadores

São Paulo 
Prof. Dr. Vahan Agopyan

Reitor da Universidade de São Paulo

Prof. Dr. Adalberto Américo Fischmann

Diretor da Faculdade de Economia, Administração e Contabilidade

Prof. Dr. Moacir de Miranda Oliveira Jr.

Chefe do Departamento de Administração

Prof. Dr. Marcelo Caldeira Pedroso

Coordenador do Programa de Mestrado Profissional em Empreendedorismo 
DAVI LASKANI HOFFMANN

\title{
Crescimento em Consultorias e Assessorias Empresariais: fatores limitantes e impulsionadores
}

\author{
Versão Corrigida
}

Dissertação apresentada ao Programa de Mestrado Profissional em Empreendedorismo do Departamento de Administração da Faculdade de Economia, Administração e Contabilidade da Universidade de São Paulo, como requisito parcial para obtenção do título de Mestre em Ciências.

Orientador: Prof. Dr. Martinho Isnard Ribeiro de Almeida

São Paulo 
FICHA CATALOGRÁFICA

Elaborada por Martha Ribeiro Neves de Vasconcellos - CRB-8/5994 Seção de Processamento Técnico do SBD/FEA/USP

Hoffmann, Davi Laskani

Crescimento em consultorias e assessorias empresariais: fatores limitantes e impulsionadores / Davi Laskani Hoffmann. - São Paulo, 2018.

$114 \mathrm{p}$.

Dissertação (Mestrado) -- Universidade de São Paulo, 2018.

Orientador: Martinho Isnard Ribeiro de Almeida

1. Pequenas e médias empresas - Aspectos administrativos 2. Microempresas 3. Consultoria de empresas 4. Crescimento I. Universidade de São Paulo. Faculdade de Economia, Administração e Contabilidade. II. Título.

CDD -658.022 
"Mais poder tem o sábio do que o forte, e o homem de conhecimento, mais do que o robusto" (Livro de Provérbios, capítulo 24, verso 5 da Bíblia Sagrada na versão Almeida Revista e Atualizada) 



\section{AGRADECIMENTOS}

Agradeço a Deus pela saúde e inspiração para ingressar neste maravilhoso programa de mestrado.

Agradeço a minha querida esposa Valéria pelo amor, apoio e suporte durante todo este processo. Sei que foi um sacrifício para você também.

Agradeço aos meus pais, Ligia e Decio, por toda dedicação e suporte para que eu chegasse até aqui.

Agradeço a DHoffmann, colaboradores, clientes e parceiros de negócio por toda paciência neste período. Também aos entrevistados que cooperaram para que esta pesquisa fosse possível.

Agradeço ao Prof. Dr. Martinho Isnard Ribeiro de Almeida, por acreditar em nossa pesquisa, ao incentivo, ao conhecimento transmitido e abertura de inúmeras possibilidades acadêmicas e profissionais ao longo do ciclo. Muito obrigado!

Agradeço a todos os professores do programa de mestrado profissional da FEA-USP. A carga de conhecimento recebida neste período é de extrema valia. Levarei para vida toda.

Agradeço a todos os meus colegas de turma, querida turma 3, pela colaboração ao aprendizado, entusiasmo e oportunidades de relacionamentos pessoais e profissionais que permanecem após a passagem por este programa.

Agradeço à Fabiana Caseiro, por todo apoio administrativo durante o processo deste mestrado. Sua ajuda é fundamental!

Agradeço a Faculdade de Economia, Administração e Contabilidade da Universidade de São Paulo pela oportunidade deste regresso. Anos após concluir a graduação nesta instituição, tive o prazer de retornar a esta casa de conhecimento. 



\section{RESUMO}

É inegável a importância das micro e pequenas empresas para a geração de riqueza destinada à nação brasileira. As micro e pequenas empresas brasileiras são responsáveis por uma parcela expressiva do PIB nacional e dos empregos formais no país. Porém, estudos demonstram que uma grande parte destas empresas são encerradas em um período curto de operação, não passando pela fase de crescimento e maturidade, por causa, basicamente, de falhas em sua gestão. A organização objeto desta pesquisa, da qual o pesquisador é sócio, passou pela transação de micro para pequena empresa durante o processo de pesquisa dessa dissertação e enfrenta o desafio de crescer. Desta forma, surgiu a questão desta pesquisa: "Como tratar os fatores limitantes e impulsionadores de crescimento de uma consultoria e assessoria empresarial?". E o seu objetivo foi de propor uma sistematização das iniciativas que iriam suplantar as limitações identificadas e que possibilitariam o crescimento da consultoria e assessoria empresarial. Inicialmente levantaram-se as causas observadas das restrições ao crescimento desta organização, elaboradas entre o pesquisador e sua equipe, são elas: recursos limitados, baixo nível de padronização e posicionamento sem clareza. Quanto ao método de pesquisa escolhido utilizou-se de pesquisa bibliográfica para atender ao objetivo secundário de identificar os fatores limitantes e impulsionadores de crescimento na bibliografia, assim como soluções para o crescimento. Dentre o referencial teórico se utilizou dos seguintes temas: as particularidades da pequena empresa e o seu ciclo de crescimento, as características empreendedoras, melhores práticas de crescimento observadas nas pequenas e médias empresas, especificidades da prestação de serviço em consultoria e estratégia e posicionamento. A fim de pesquisar melhores práticas para crescimento existentes em consultorias ou assessorias empresariais realizaram-se 6 entrevistas semiestruturadas com proprietários de empresas prestadoras de serviço e correlatas ao segmento da organização estudada que passaram por um processo de crescimento. Da teoria e das entrevistas foram elencados 9 limitadores do crescimento empresarial. Das entrevistas elencaramse 23 impulsionadores de crescimento e estes foram relacionados aos limitadores, gerando uma matriz relacional. Por fim, para elaborar uma sistematização das iniciativas que iriam suplantar as limitações identificadas e que possibilitariam o crescimento da consultoria e assessoria empresarial foi utilizado o método de pesquisa-ação. Através dos limitadores e impulsionadores identificados, além dos exemplos práticos citados pelos entrevistados, o pesquisador listou 17 iniciativas que compuseram um plano de intervenção, ou seja, uma sistematização. Ao longo da pesquisa, 5 das 17 iniciativas foram implantadas na organização estudada e os resultados observados. A média do faturamento bruto mensal da organização dobrou entre o período anterior ao início da pesquisa e o período posterior ao início da pesquisa, denotando uma correlação positiva às implantações de algumas iniciativas do plano de intervenção, não se limitando apenas às interferências destas variáveis. As limitações constatadas para esta pesquisa foram a falta de tempo (por se tratar de um mestrado) de aplicar o plano de intervenção na íntegra e também uma pesquisa quantitativa para validar este plano. Como contribuição desta pesquisa, espera-se que empresários ou aspirantes, que passam por situações semelhantes às enfrentadas pelo pesquisador, possam utilizar-se das evidências práticas deste material aplicando-o em suas próprias organizações.

Palavras-chave: Pequenas Empresas. Consultoria Empresarial. Assessoria Empresarial. Estratégia de Crescimento. Escalabilidade. 


\begin{abstract}
The importance of micro and small companies for the generation of wealth destined for the Brazilian nation is undeniable. Brazilian micro and small enterprises are responsible for a significant share of national GDP and formal jobs in the country. However, studies show that a large part of these companies are shut down in a short period of operation, do not cross the growth and maturity phase, basically due to failures in their management. The organization object of this research, of which the researcher is a partner, went through the transaction from micro to small company during the research process of this dissertation and faces the challenge of growing. In this way, the question of this research appeared: "How to deal with the limiting factors and growth promoters of a business consulting and advisory?". Its objective was to propose a systematization of the initiatives that would overcome the limitations identified and that would enable the growth of business consulting and advisory services. Initially, it raised the observed causes of restrictions of growth of this organization, elaborated between the researcher and his team, it are: limited resources, low level of standardization and positioning without clarity. Regarding the chosen research method, a bibliographic search was used to meet the secondary objective of identifying the limiting factors and growth promoters in the bibliography, as well as solutions for growth. Among the theoretical references, the following themes were used: the particularities of the small company and its growth cycle, the entrepreneurial characteristics, the best practices of growth observed in small and medium enterprises, the specifics of the service rendering in consulting and strategy and positioning. In order to research best practices for growth existing in consultancies or business advisors, six semi-structured interviews with owners of service companies and correlated to the segment of the organization object of this research, which underwent a process of growth, were carried out. From the theory and the interviews were listed 9 limiters of business growth. Of the interviews, 23 growth promoters were listed and these were related to the limiters, generating a relational matrix. Finally, in order to elaborate a systematization of the initiatives that would overcome the identified limitations and that would allow the growth of the consulting and business consultancy, the action-research method was used. Through the identified limiters and drivers, in addition to the practical examples cited by the interviewees, the researcher listed 17 initiatives that comprised an intervention plan, that is, a systematization. Throughout the research, 5 of the 17 initiatives were implemented in the organization object of this research and the results observed. The average gross monthly turnover of the organization doubled between the period prior to the start of the survey and the period after the start of the survey, indicating a positive correlation to the implementation of some initiatives of the intervention plan, not limited to the interference of these variables. The limitations found for this research were the lack of time (because it is a master's degree) to apply the intervention plan in full and also a quantitative research to validate this plan. As a contribution of this research, it is expected that entrepreneurs or aspirants, who undergo similar situations to those faced by the researcher, can use the practical evidence of this material applying it in their own organizations.
\end{abstract}

Keywords: Small Business. Business consulting. Business advice. Growth Strategy. Scalability. 


\section{LISTA DE FIGURAS}

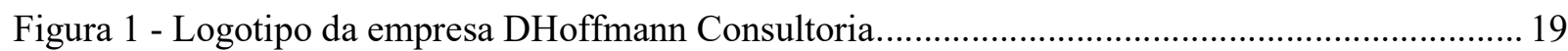

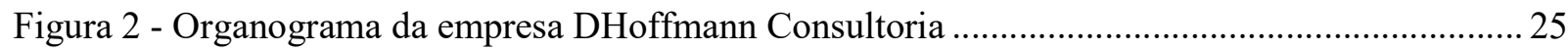

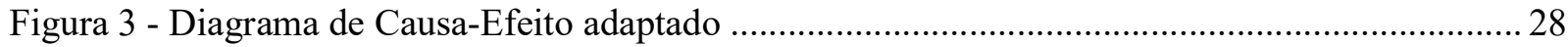

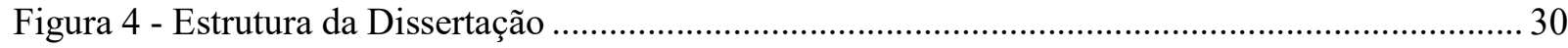

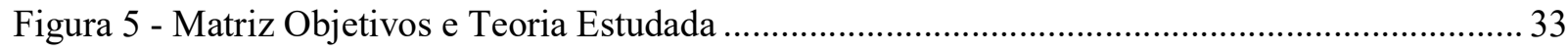

Figura 6 - Porte Empresa por Número de Funcionários .......................................................................... 35

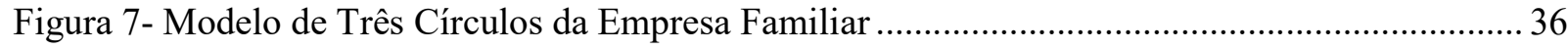

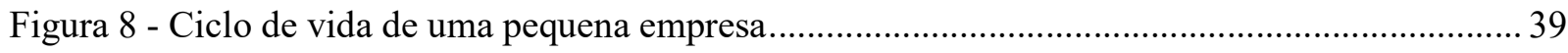

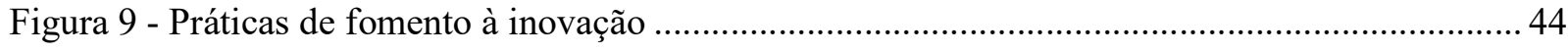

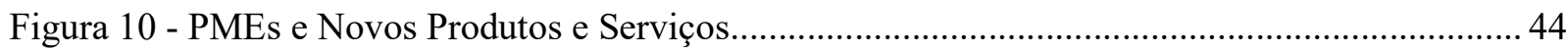

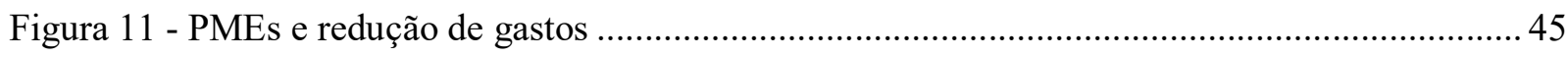

Figura 12 - PMEs e Ações para manutenção de crescimento até 2020 ............................................... 46

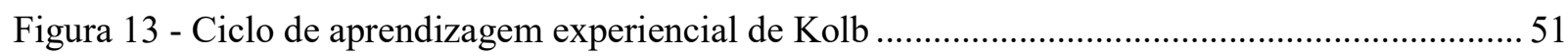

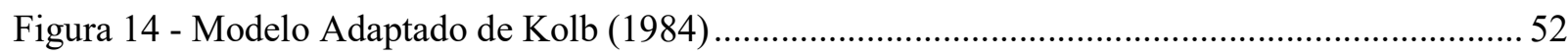

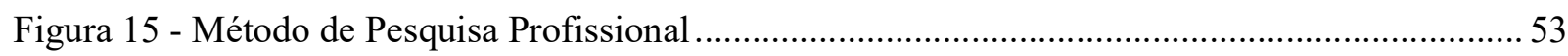

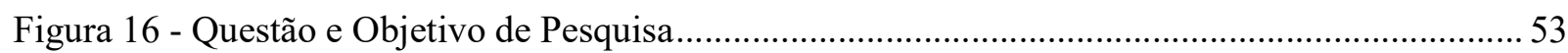

Figura 17 - Quadro Relacional entre objetivos e métodos de pesquisa ..............................................54

Figura 18 - Matriz Tipo de Investigação versus atuação na prática ………………………………........56

Figura 19 - Ciclo da Pesquisa-Ação segundo Kurt Lewin ..................................................................57

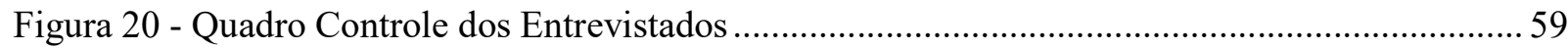

Figura 21 - Relação da Segmentação do Problema com Objetivo e Questões de Pesquisa .................. 60

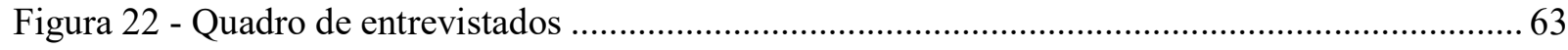

Figura 23 - Fatores Limitadores do Crescimento Empresarial ............................................................ 73

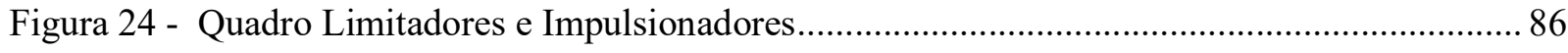

Figura 25 - Lista de Iniciativas participantes do plano de intervenção .................................................99

Figura 26 - Matriz relacionando impulsionadores e iniciativas ....................................................... 100

Figura 27 - Evolução do Faturamento Médio Mensal DHoffmann Consultoria................................. 102

Figura 28 - Lista de intervenções já realizadas ........................................................................... 102

Figura 29 - Matriz Geral de Relação Limitadores, Impulsionadores e Intervenções ......................... 103

Figura 29 - Matriz Geral de Relação Limitadores, Impulsionadores e Intervenções .................. 104 


\section{LISTA DE ABREVIATURAS E SIGLAS}

CNPJ Cadastro Nacional da Pessoa Jurídica

CRM Customer Relationship Management

DIEESE Departamento Intersindical de Estatística e Estudos Socioeconômicos

ERP Enterprise Resource Planning

FEA-USP Faculdade de Economia, Administração e Contabilidade da USP

IPEA Instituto de Pesquisa Econômica Aplicada

MBA Master in Business Administration

MPE Micro e Pequenas Empresas

ONU Organização das Nações Unidas

PDCA Plan, Do, Control, Act

PIB Produto Interno Bruto

PME Pequenas e Médias Empresas

SEBRAE Serviço Brasileiro de Apoio às Micro e Pequenas Empresas

USP Universidade de São Paulo 


\section{SUMÁRIO}

1 INTRODUÇÃ

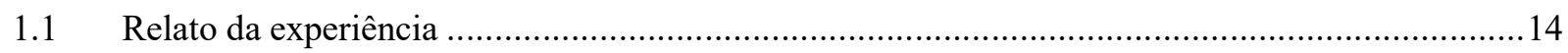

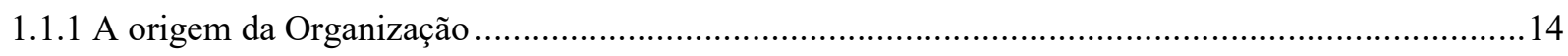

1.1.2 Evolução da Organização até o Início do Mestrado Profissional....................................................20

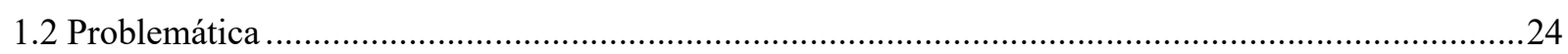

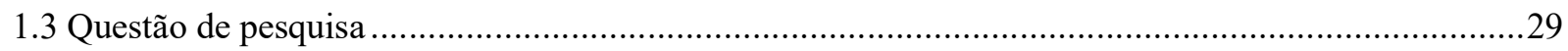

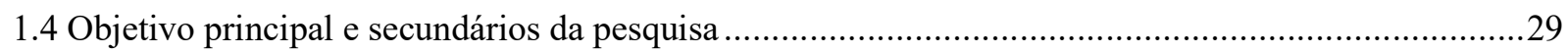

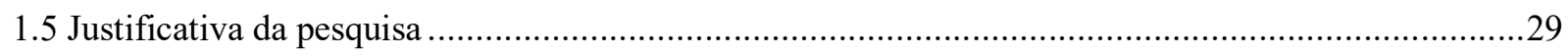

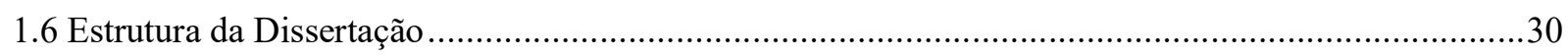

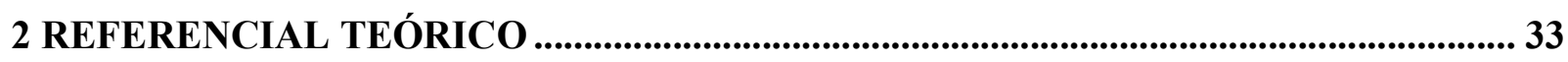

2.1 A Pequena Empresa, características, especificidades e ciclo de vida ...............................................34

2.1.1 A Pequena Empresa, características e especificidades ....................................................................

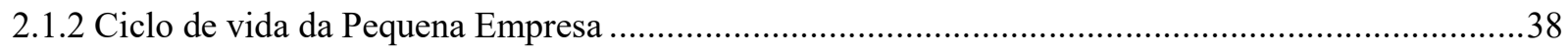

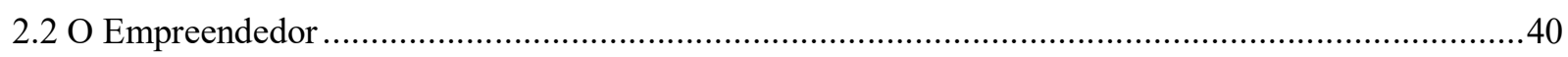

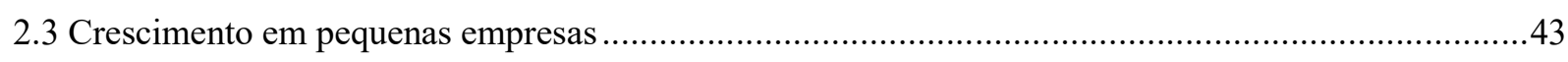

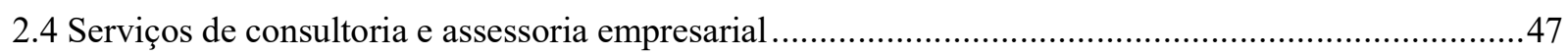

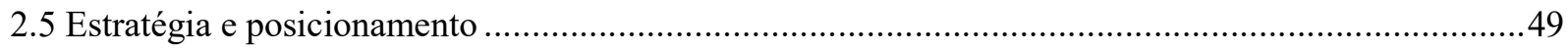

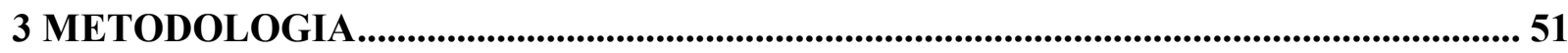

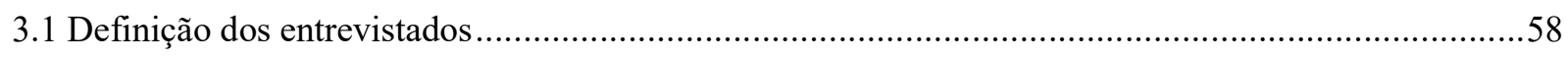

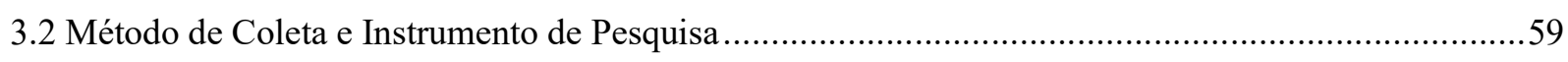

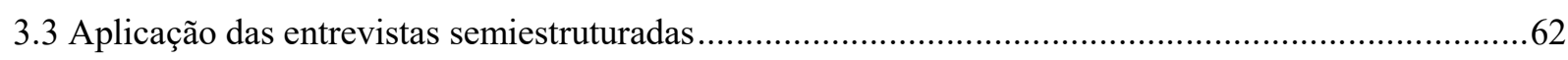

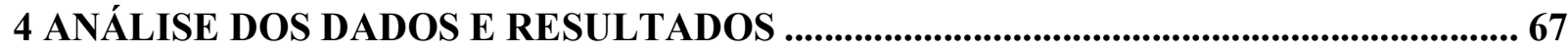

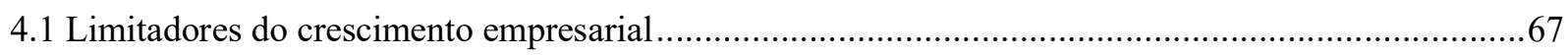

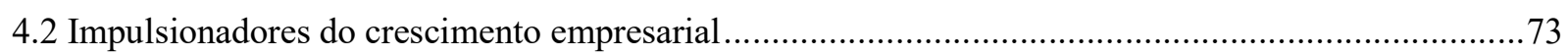

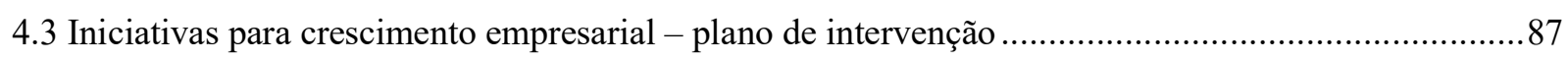

5 CONSIDERAÇÕES FINAIS, LIMITAÇÕES E ESTUDOS FUTUROS .......................... 105

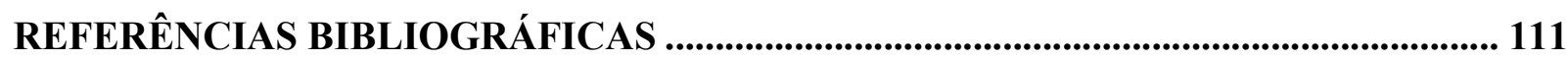





\section{INTRODUÇÃO}

Segundo estudo encomendado pelo Sebrae com o título 'Participação das Micro e Pequenas Empresas na Economia Brasileira', de julho de 2014, cerca de 9 milhões de micro e pequenas empresas brasileiras são responsáveis por, aproximadamente, 27\% do PIB nacional e $52 \%$ dos empregos formais no país. Estes índices cresceram nos últimos anos denotando que este conjunto de empresas é expressivo e tem se tornado cada vez mais importante para a economia do país. Segundo Luiz Barretto, Diretor-Presidente do Sebrae Nacional à época da pesquisa, "Os dados demonstram a importância de incentivar e qualificar os empreendimentos de menor porte, inclusive os Microempreendedores Individuais" (SEBRAE, 2014, p. 6).

Esta mesma expressividade é declarada em dois estudos, um do Sebrae/SP, denominado 'Panorama das MPEs paulistas 2015', e um do Ipea (IPEA, 2012), denominado 'Micro e Pequenas Empresas Mercado de Trabalho e Implicação para o Desenvolvimento'.

Por outro lado, segundo outro estudo do próprio Sebrae sob o título 1Causa Mortis - O sucesso e o fracasso das empresas nos primeiros 5 anos de vida', de julho de 2014 (mais atual encontrado até confecção desta dissertação), uma grande parte destas empresas são encerradas em um período curto de operação (58\% em até 5 anos, segundo o estudo "Panorama das MPEs paulistas 2015" do Sebrae/SP) por causa de falhas no planejamento prévio, deficiências na gestão empresarial e comportamento empreendedor inadequado. Além disto, o ambiente brasileiro é classificado como hostil para novos empreendimentos segundo estudo do Banco Mundial (THE WORLD BANK GROUP, 2016).

Por própria observação e constatação do autor, que é Sócio e Consultor Sênior da DHoffmann Consultoria (empresa especializada em atender operações de menor porte), com a realização de atendimentos e projetos executados para pequenas empresas verificam-se os mesmos pontos como dificuldades do empresariado com algum detalhamento: dificuldade de execução, pouco acesso a crédito, dificuldade em traçar e reorientar estratégia, baixo nível de segurança no sistema de governança corporativa, falta de controle, dificuldades em gestão de pessoas e dificuldades financeiras em geral. Portanto, evoluir em boas práticas de gestão é um ponto crucial a este segmento.

Desta forma, e ao longo do tempo, constituíram-se consultorias, consultores autônomos e assessorias empresariais com foco em atender este segmento promissor, além de todo trabalho desenvolvido pelo próprio Sebrae. Estes esforçam-se em buscar apoiar os clientes na implantação de processos e ferramentas consagradas dentro do âmbito das boas práticas de gestão, incluindo nesses a empresa do próprio autor. 


\subsection{Relato da experiência}

Tratando-se de uma pesquisa de origem profissional, o objeto de estudo desta é derivada da própria experiência prática do autor. Compõem o relato desta experiência a origem da organização fundada pelo autor, a "DHoffmann Consultoria", e sua evolução, explicitadas nos próximos tópicos.

\subsubsection{A origem da Organização}

O autor se graduou em Administração de Empresas pela Universidade de São Paulo no ano de 2003. Antes disso iniciava sua carreira, como a maioria dos que passam pela mesma formação, realizando estágios em grandes empresas.

Antes de seu primeiro vínculo trabalhista, estagiou em quatro organizações de setores distintos nas quais pôde experimentar algumas áreas e atividades diferenciadas: consultoria pública, atendimento em aeroporto, departamento de suprimentos e departamento de informações gerenciais. Com a experiência e resultado observado nesta última área citada, de Informações Gerenciais, foi convidado a entrar na área de relacionamento com clientes (em inglês Customer Relationship Management, ou a famosa sigla CRM) como recurso humano efetivo, ou seja, com vínculo empregatício e cargo de analista. Tratava-se de uma startup (empresa iniciante) do mercado financeiro, uma corretora de investimentos (o termo à época era "boutique de investimentos", pois captava recursos de pessoas físicas com renda média e alta para investir cotas em grandes fundos de investimentos) de um grande banco alemão. Isto ocorreu no início do ano 2002. As atividades esperadas dele foram relacionadas à análise de dados e relatórios gerenciais, algo já trabalhado no estágio e que, posteriormente, seria verificado como um grande direcionador de carreira, uma competência desenvolvida e validada (capacidade analítica, de transformar dados em informações).

Nesta mesma organização o autor também passou por seu primeiro e único desligamento por parte do empregador, aproximadamente um ano e meio após sua efetivação. A empresa não cumpriu com seus objetivos iniciais acordados com os acionistas estrangeiros e logo foi vendida para um grande banco estatal brasileiro, com a missão de se tornar a plataforma premium deste banco, que não existia até o momento. $\mathrm{O}$ fato é que a carteira de clientes (seus recursos aplicados) e a operação foram incorporadas ao banco brasileiro e a plataforma original foi descontinuada. Em um só dia foram desligados mais da metade dos 
funcionários contratados. Todos estes adventos e as atividades em si executadas nesta organização foram de grande aprendizado para o autor, em seu início de carreira.

Após esta experiência, se recolocou na área de produtos de uma grande organização do setor de saúde (administração de planos de saúde e rede de atendimento médico). Como analista, suas atividades prosseguiram em analisar dados, transformá-los em informação e apoiar a tomada de decisão no nível gerencial e diretivo. Nesta empresa teve a oportunidade de apresentar dados e recomendações para presidência de um grande grupo pela primeira vez. Permaneceu nesta até meio do ano 2005, quando aceitou o desafio de outra organização.

Em 2005 entrou em uma grande organização do setor de telecomunicações. O setor havia passado anteriormente por um processo de privatização e a profissionalização era intensa, muito acelerada, sem contar a evolução tecnológica. A organização era muito dinâmica. Seu cargo era de analista de planejamento comercial sênior, desenvolvendo um trabalho orientado a resultado, intenso em análise de dados, ferramentas de tecnologia e sistemas e muito relacionamento pessoal (em uma estrutura organizacional bem ampla). Nesta organização pôde praticar pela primeira vez uma função de liderança, mesmo que temporária e sem o devido cargo, quando liderou uma célula de trabalho por alguns meses.

No início de 2007 tomou a decisão de acompanhar sua família, que retornou a residir na região de Campinas/SP. O autor, apesar de nascido em São Paulo, passou a infância e adolescência na cidade de Campinas/SP até ingressar na Universidade de São Paulo para a graduação. Desta forma, aceitou o convite de uma empresa nacional, líder em seu segmento (análises químicas de água, solo, efluente, emissão atmosférica, conhecidas como análises ambientais), em fevereiro de 2007. Iniciou com o cargo de coordenador de planejamento e controle de vendas, implantando e expandindo este departamento. Quando saiu, em março de 2013, ocupava o cargo de gerente de planejamento e controle. O processo de aprendizagem nesta empresa foi acelerado e intenso, gerando uma experiência ímpar para o autor. Isto porque a empresa passou por um processo rápido de profissionalização, expansão de suas atividades e venda a um grupo francês. $\mathrm{O}$ autor participou ativamente de várias etapas e interação com diretores, vice-presidentes e sócios, apoiando o processo decisório. Inclui-se a estas etapas o fato de ter sido escolhido para ser capacitado como auditor interno da holding francesa (capacitação realizada em Lyon, na França), único no Brasil até aquele determinado momento. Também pôde gerenciar equipes multidisciplinares e em áreas distintas como: vendas, marketing, planejamento comercial, planejamento e controle, assessoria direta ao vice-presidente, inteligência de negócios (business intelligence), back-office comercial, coleta de amostras (área operacional). Igualmente liderou projetos e iniciativas estratégicas como 
orçamento empresarial, modelo de expansão de filiais, modelo de remuneração de executivos e implantação de balanced scorecard. O trato com estes projetos possibilitou o desenvolvimento de habilidades com finanças e culminou na execução de uma pós-graduação (em formato de $M B A$ ) concluída em 2014, executada na Fundação Getúlio Vargas. Toda esta experiência reforçou ainda mais a competência de apoiador da decisão empresarial e despertou o interesse em experimentar projetos de consultoria empresarial para outras empresas e o desejo de apoiar empresários com organizações pequenas e médias. Até aquele momento sua motivação era verificar o resultado de suas recomendações (no negócio de seus possíveis clientes) e também o ensino, algo que sempre o cativou e que via relação ao processo de consultoria empresarial (como canal transmissor de conhecimento a quem o recebe).

Desta forma, em meados de 2009, quando o autor encontrou alguns amigos de infância, empresários na cidade de Campinas/SP, propôs a realização de sua primeira consultoria empresarial a eles. Seus amigos possuíam duas lojas de centros automotivos (oficinas mecânicas para automóveis) e externavam a dificuldade de entender o negócio, principalmente quanto aos resultados financeiros e como revertê-los. Iniciou-se, assim, a sua primeira prestação de serviço de consultoria, ainda como consultor autônomo, concomitantemente ao seu vínculo empregatício, nas horas vagas (à noite e final de semana) e com pagamento em permuta de serviços mecânicos em seu próprio automóvel.

$\mathrm{O}$ primeiro projeto e cliente foi conquistado. Este permaneceu com atendimento contínuo durante, aproximadamente, sete anos e foi muito importante para testar o atendimento e, principalmente, validar a premissa de migração de carreira posteriormente. Durante os primeiros anos de atendimento o autor pôde verificar as evoluções no negócio de seu cliente em termos de: conhecer os números do negócio, implantar controles financeiros, diminuição da dependência dos sócios à operação, reestruturação organizacional, reestruturação de passivo financeiro, mudança de posicionamento de marca, projetos de viabilidade financeira em novos negócios e pontos comerciais e pesquisa de mercado. $\mathrm{Ou}$ seja, foram inúmeras iniciativas que possibilitaram uma mudança positiva do negócio a quatro mãos, empresário e consultor.

Ainda durante o seu vínculo empregatício, o autor executou outras iniciativas ligadas à consultoria, como treinamentos livres. Realizou dois cursos sobre "Finanças para Não Financeiros", um para a equipe de seu cliente (oficina mecânica) e outro para a equipe de uma consultoria de recursos humanos, contato este levantado por indicação de seus clientes. Neste momento despertou para a importância de utilizar sua rede de contatos para gerar novos 
negócios e também para a satisfação em compartilhar conhecimento, através do treinamento realizado.

Estas experiências somadas fizeram com que o autor refletisse sobre sua carreira. Não havia nada de errado na carreira que seguia como executivo (já com o cargo de gerente). A empresa que estava já havia sido completamente vendida para um grande grupo francês, a estrutura organizacional e modelo de governança passavam por transformações e o autor assumia cada vez mais responsabilidades (novos departamentos, liderança de projetos estratégicos, interface com o grupo empresarial francês), enfim, uma carreira em plena ascensão. Porém, o modo de trabalhar em projetos de consultoria e treinamentos trouxe uma satisfação e desafio que não existiam na função e cargo que ocupava, ou em posições executivas. O desafio de trabalhar com múltiplos segmentos simultaneamente (desta forma acelerando um processo de aprendizagem em termos de conhecimento de estruturas distintas e modelo de resultado econômico-financeiro), o fato de trabalhar com pequenas e médias empresas (multidisciplinariedade e recursos limitados, bem diferente de um ambiente de grande empresa), ter a possibilidade de ensinar e aprender (nos treinamentos e no próprio processo de consultoria e assessoria empresarial) e, principalmente, verificar o resultado prático das recomendações ou implantações de ações foram fatores que fizeram com que o autor tomasse a decisão de migrar a carreira de executivo (com vínculo empregatício) para consultor empresarial (com o próprio negócio).

Além destes fatores motivacionais apresentados no parágrafo anterior, obviamente o autor se atentou para outros fatores (atratividade de mercado, modo de trabalho e renda própria) observados por ele neste processo decisório:

- Pouco conhecimento de ferramentas e processos de gestão por parte dos proprietários e funcionários de uma PME no Brasil;

- Carência de consultorias e consultores habilitados para atender PME (pelas particularidades observadas);

- Possibilidade de administrar seus próprios recursos (tempo e dinheiro, em seu próprio negócio);

- Possibilidade de iniciar um negócio e ter elevação da renda familiar.

Desta forma, o autor decidiu, de forma transparente, comunicar ao seu superior imediato sobre a decisão de desligamento da empresa e iniciar uma nova trajetória profissional. Foi realizada uma transição suave a fim de formar um substituto para a sua 
função antes do desligamento oficial. Isto percorreu, aproximadamente, um ano de trabalho. Neste um ano o autor, aspirante a empresário, pôde se dedicar a planejar o novo empreendimento. Este planejamento percorreu algumas etapas:

- Decidir se iria ser um consultor autônomo ou proprietário de uma empresa de consultoria empresarial;

- Entender o mercado, público-alvo, desejos e necessidades do mercado;

- Definir um nome, marca e ter uma identidade visual;

- Definir o portfólio de serviços;

- Ter um website, folder e cartão de visitas;

- Definir política de preços;

- Definir estratégia comercial;

- Realizar um planejamento financeiro pessoal para sustentar o início do negócio.

Um parceiro (o mesmo consultor de recursos humanos citado anteriormente) apoiou com algumas sessões de aconselhamento para ajudar no direcionamento do posicionamento da nova carreira. Destas sessões surgiu a definição de que o autor gostaria de ter uma consultoria, ou seja, uma estrutura organizacional em que ele como recurso estivesse inserido, não limitado a ele mesmo. A decisão de ser empresário e não autônomo foi tomada.

Outro parceiro, um instituto de inteligência conhecido em seu último vínculo empregatício (e é parceiro de negócios até o momento da realização desta dissertação), realizou uma pesquisa de opinião pública a fim de verificar as características do público e como atingi-lo. A pesquisa validou a carência existente no mercado (já observada) e direcionou para a necessidade mapeada, que era ter na prestação de serviço um atendimento próximo e muita praticidade na entrega, ou seja, este público (de PMEs) deseja contratar consultoria, porém tem pouco tempo para interagir e implantar ações.

Para a definição do nome, marca e identidade visual, o autor contou com uma agência publicitária (a qual realizou permuta no desenvolvimento em troca de serviço de consultoria). A agência apoiou na definição do nome, desenhou o logotipo, criou o primeiro folder e cartão de visita. $\mathrm{O}$ nome escolhido deveria remeter à pessoa do consultor, mas, ao mesmo tempo, ser um nome de uma pessoa jurídica. DHoffmann foi o nome escolhido; o " $\mathrm{D}$ " inicial do primeiro nome do autor e o "Hoffmann" de seu último sobrenome. A assinatura do nome foi determinada como "Consultoria", portanto, até os dias desta dissertação, a marca é citada 
como "DHoffmann Consultoria". O logotipo (Fig. 1) foi criado e um símbolo anexado remetendo à ideia de ligação, caminho para chegar a algum lugar ou objetivo.

Figura 1 - Logotipo da empresa DHoffmann Consultoria

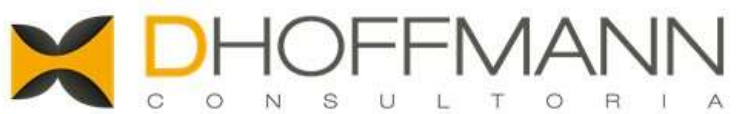

Fonte: Autoria própria (2013).

A definição do portfólio inicial de serviços se deu perante as experiências que o autor teve até então, seus conhecimentos práticos e teóricos até o momento e as necessidades observadas do público-alvo. Basicamente o portfólio girou em torno do processo de realização de diagnóstico, desenho da solução, implantação, controle de resultados e correção de rota, ou seja, em um ciclo de gerenciamento em quatro grandes áreas do conhecimento em administração e funções:

- Financeiro: conhecer a performance empresarial, recomendações para melhoria de performance, reestruturação de endividamento, descontrole do fluxo de caixa e análise de investimentos;

- Vendas: diagnosticar e fornecer soluções para incremento de vendas ou margens;

- Controle: conhecer os indicadores críticos para o negócio, acompanhar os indicadores e associar a ações, evitar fraudes (pontos de controle);

- Planejamento: realizar planejamento de curto, médio e longo prazo, determinar posicionamento frente ao mercado e obter dados de mercado.

O primeiro website foi criado por um dos primeiros clientes e também a permuta foi realizada com sucesso.

A política de preços foi associada ao planejamento financeiro pessoal. É importante ressaltar a importância da família no processo de transição ao qual o autor passou. O apoio de sua esposa foi fundamental para a tomada de decisão (troca de carreira). Ela o incentivou totalmente, mesmo ele sendo o gerador da renda familiar. Também era um sonho dela ter a empresa gerenciada pela família. Portanto, o planejamento financeiro foi realizado em conjunto. Eles prepararam uma reserva financeira emergencial (entre quatro e seis meses do custo mensal) e reduziram todos os custos do casal (um exemplo foi a troca do plano de saúde para um de baixo custo, outro a redução dos gastos com lazer). A política de preços (valores a serem cobrados dos clientes por hora trabalhada) tinha uma primeira orientação de igualar a 
renda obtida através do vínculo empregatício, ou seja, a hora trabalhada se igualava ao valor recebido como funcionário. $\mathrm{O}$ autor, na realidade, não sabia como o mercado iria se comportar a respeito de precificação, e preferiu iniciar com um modelo simples, ter o aprendizado inicial e adaptar posteriormente. A primeira meta era igualar a renda familiar obtida através do vínculo empregatício. Até aquele momento o trabalho seria como se fosse um autônomo em sua essência, portanto, confundiam-se os fluxos financeiros pessoais com os da nova organização. O desafio inicial seria conquistar os primeiros clientes.

A pesquisa de opinião pública mostrou que o canal de venda mais eficiente seria extremamente pessoal, ou seja, oriundo de relacionamento. Desta forma, o autor criou uma estratégia comercial de tecer ações de relacionamento com sua família, amigos, depois clientes atuais e parceiros de negócio, iniciando por comunicar a todos de sua decisão e nova oferta ao mercado.

Com este planejamento definido (observa-se que não foi extremamente detalhado, como um planejamento estratégico padrão) só restavam duas questões a serem resolvidas: a data do desligamento real do vínculo como empregado (e, consequentemente, marcando o início da DHoffmann Consultoria) e iniciar com alguns clientes na carteira.

O primeiro cliente do portfólio (a oficina mecânica) permaneceu na carteira, já em modo de assessoria empresarial, garantindo, assim, um valor fixo mensal para o consultor. $\mathrm{O}$ segundo cliente seria uma empresa iniciante no ramo de bares e restaurantes, o qual teria o seu superior imediato como um dos sócios. Também uma assessoria para realizar o plano financeiro do negócio e apoiar o monitoramento mensal. Sendo assim, o autor iniciou o seu empreendimento com dois clientes na carteira e uma renda mensal "garantida" oriunda destes clientes, mas aquém do custo mensal familiar. Este fato aconteceu no início de março do ano 2013. Nascia, então, a "DHoffmann Consultoria".

\subsubsection{Evolução da Organização até o Início do Mestrado Profissional}

Nos primeiros seis meses da organização, o proprietário-consultor (o autor) focou em angariar novos clientes para atingir a primeira meta organizacional, igualar a renda anterior obtida como funcionário. Além disto, controlou os gastos realizando o trabalho com escritório na residência (home-office), formalizou a empresa (abrindo CNPJ) e garantiu uma boa entrega aos clientes vigentes à época.

Para angariar os novos clientes utilizou-se da estratégia comercial traçada de relacionamento. Realizou inúmeras reuniões (muitas em restaurantes ou cafés) com amigos, 
ex-colegas de trabalho, familiares e clientes apresentando a sua nova empresa e solicitando indicações de negócios. Além disso, teve a mesma postura com os parceiros comerciais à época e iniciou possíveis contatos com futuros parceiros em negócios complementares, tais como advogados, contadores e outros consultores. Naquele momento entendeu que estabelecer parceria comercial seria importante para geração de novos negócios e também para indicar bons fornecedores aos seus clientes, além de obter sinergias em áreas complementares em futuros projetos a clientes.

No primeiro mês de operação a renda superou os gastos da família. Em quatro meses de operação já havia atingido a sua primeira meta, igualar a renda como funcionário. Em doze meses havia dobrado. E os novos negócios gerados foram todos oriundos de indicação, ou seja, do relacionamento formado com os contatos citados. Além da venda de projetos de consultoria e assessoria empresarial, iniciou-se a revenda de pesquisas de opinião pública através do parceiro comercial estabelecido.

Como o intuito original era de estruturar uma consultoria (uma empresa), após quinze meses de operação com apenas um recurso (o próprio proprietário-consultor) e trabalhando da própria residência, o autor decide ter o próprio escritório, oficializar o apoio da esposa como recurso humano da empresa e contratar seu primeiro funcionário. A esposa, até esta altura, era sócia legal da empresa e trabalhava parcialmente apoiando em tarefas administrativas, como emissão de nota fiscal de serviço. Desta forma, foi locada uma sala comercial e mobiliada. A esposa iniciou um trabalho de período integral na consultoria como responsável pelas atividades administrativas, financeiras e comerciais. Foi contratado um primeiro funcionário para auxiliar o consultor, um auxiliar para as tarefas operacionais. Isto ocorreu em setembro de 2014. Neste ponto a empresa tomou um novo posicionamento, com estrutura para receber clientes, dar vazão com mais agilidade às entregas e, por outro lado, uma nova estrutura de gastos, com ampliação (dividiu-se, então, os resultados da pessoa jurídica da pessoa física) e investimentos sendo realizados. Ao final de 2015, para obter redução de gastos, decidiu-se retornar ao modelo de escritório e residência no mesmo local. O funcionário se desligou também neste ano, fato que será detalhado mais à frente neste documento. E neste formato a empresa permaneceu até o início desta pesquisa, como uma microempresa. Para efeito desta pesquisa, juntamente com seu orientador, o pesquisador utilizou o livre conceito de microempresa, sendo o seguinte: tem como característica marcante a atuação empresarial estar amplamente centrada em seu proprietário-executor e fisicamente em sua residência. De fato, a DHoffmann Consultoria era uma microempresa ao iniciar esta pesquisa, no programa de mestrado profissional. 
Até o momento da confecção desta dissertação (62 meses de operação), a DHoffmann Consultoria realizou, aproximadamente, 110 atendimentos (entre projetos, assessoria empresarial contínua e treinamentos executados). Destes, apenas 6 (ou 5\%, aproximadamente) não foram através de indicação; encontraram a consultoria através da internet. A primeira conquista sem ser por indicação ocorreu com 26 meses de operação. A empresa conta em sua estrutura com dois funcionários (um sênior e um júnior), dois sócios (o casal), e está em seu terceiro espaço físico.

O público-alvo da empresa continua sendo as pequenas e médias empresas (PME), de qualquer segmento e de qualquer localidade geográfica, na missão de compartilhar conhecimentos e implantar soluções empresariais que propiciem grandes resultados revertidos, de forma direta ou indireta, em ganhos para a empresa e a sociedade.

A DHoffmann possui como seus principais valores e pensamentos:

- Ética e transparência nas relações;

- Que possuir objetivos e metas definidas é essencial a qualquer empreendimento;

- Que sempre é possível melhorar;

- Que construir algo coletivamente potencializa o resultado;

- Que devemos ter equilíbrio entre teoria e prática para obtenção de resultados concretos.

Comparando com o portfólio original de serviços houveram poucas evoluções, apenas os serviços ficaram mais explícitos dentro do aprendizado gerado nos primeiros anos de operação. Houve também algum grau de adaptação dos serviços ao perfil dos clientes, gerando uma metodologia específica de atendimento (apesar de não estar formalizada, documentada até o momento). Diante disto, dentro de seu portfólio encontram-se serviços executados comprovados, de consultoria e assessoria empresarial, nas seguintes áreas e com o seguinte agrupamento:

- Gestão Financeira (diagnóstico, sistema de custos, melhorias de fluxo de caixa, melhorias de margem econômica);

- Gestão Comercial (planejamento comercial, sistemas de remuneração variável);

- Planejamento e Controle (processo de planejamento e estabelecimento de controles para processos financeiros, comerciais);

- Plano de Negócios (Business Plan, Avaliação de Empresas); 
- Pesquisa de Mercado (Aplicação com Instituto de Inteligência);

- Recuperação de Empresas (diagnóstico e apoio à implantação, ciclo PDCA);

- Cursos e Palestras (nas diversas esferas dos conhecimentos citados).

O modo de atendimento atual pode ser discriminado conforme os tópicos abaixo. A precificação atual evoluiu comparada à inicial, em que era explícito o valor por hora ao cliente:

- Projetos de Consultoria: o escopo é bem-definido e as etapas explícitas. Existe, com muita clareza, a definição das entregas do projeto, seu início, meio e fim. O preço é fechado para a entrega de todo o projeto;

- Assessoria Empresarial: o escopo não é muito bem-definido. Há alocação de horas de consultores para acompanhamento contínuo de atividades, como análises, recomendações ou implantações. Tem caráter de prazo indeterminado. O preço é uma mensalidade;

- Consultoria Express: realização de consultas pontuais sobre determinado assunto. O preço é por consulta realizada;

- Cursos e treinamentos: realização de cursos livres abertos ao público ou modelados para determinado cliente. O preço é por curso executado (quando para uma empresa específica) ou por ingresso (quando o curso é aberto);

- Palestras: realização de palestras abertas ao público ou modeladas para determinado cliente. O preço é por palestra executada (quando para uma empresa específica) ou por ingresso (quando a palestra é aberta).

Como canais de divulgação e de venda são utilizados:

- Um blog associado ao website da empresa;

- Um blog pessoal do consultor-líder;

- Canal em mídia social: Facebook, Instagram, Youtube;

- Localização em mecanismos de busca, tais como Google;

- Rede de parceiros comerciais e técnicos desenvolvida;

- Realização de palestras, entrevistas, treinamentos, sempre quando convidado ou organizado pela própria organização;

- Participação em eventos empresariais, rodadas de negócio e grupos de rede de contatos. 
Com sede em Campinas/SP, a empresa atende clientes do interior de São Paulo, da Grande São Paulo/SP e Grande Belo Horizonte/MG. Atualmente possui uma estrutura enxuta de recursos humanos, conforme já citado.

Nesta trajetória, desde sua abertura, o autor observou que existem dificuldades na concepção e implantação de projetos de consultoria clássicos (definem-se por métodos tradicionais os aplicados a grandes organizações) para PMEs, por alguns motivos:

- A falta de recursos financeiros para viabilizar projetos que demandem maior carga de hora / homem;

- Desconhecimento por parte do empresariado de teoria administrativa e dos serviços de consultoria (tendência a banalizar o uso ou buscá-lo em último caso de forma corretiva e não preventiva);

- A falta de tempo e disciplina para execução das ações derivadas do diagnóstico;

- Restrição de outros recursos em geral.

Por outro lado, é visto que os casos de sucesso são aqueles em que havia prédisposição à contratação (oriunda de um conhecimento do serviço ou indicação deste), houve algum grau de adaptação do projeto e métodos à realidade do cliente, houve apoio na implantação e monitoramento das decisões gerenciais, houve transmissão do conhecimento de teoria administrativa e adaptação do preço de venda. Na maioria dos casos, os projetos convertem-se em serviço contínuo de assessoria empresarial com objetivo de acompanhar os clientes em diversas implantações e suporte à decisão, resultado do alto grau de confiança gerado pelos trabalhos entregues.

Apesar do conhecimento das dificuldades e motivadores de sucesso, a empresa ainda busca um modelo mais eficiente para atender seus clientes e possibilitar seu próprio crescimento, ganhando escala.

\subsection{Problemática}

A DHoffmann Consultoria executou projetos de consultoria e serviço de assessoria em, aproximadamente, 110 atendimentos distintos desde sua fundação (95\% dos clientes foram conquistados por indicação), em diferentes áreas de atuação. 
Atualmente, no momento da redação desta dissertação, possui uma estrutura enxuta de trabalho composta por (Fig. 2):

- Um consultor sênior (o próprio autor);

- Um assistente administrativo financeiro;

- Um analista sênior (consultor em formação);

- Um assistente operacional (que responde ao analista sênior);

- Parceiros de negócio em áreas distintas.

Figura 2 - Organograma da empresa DHoffmann Consultoria

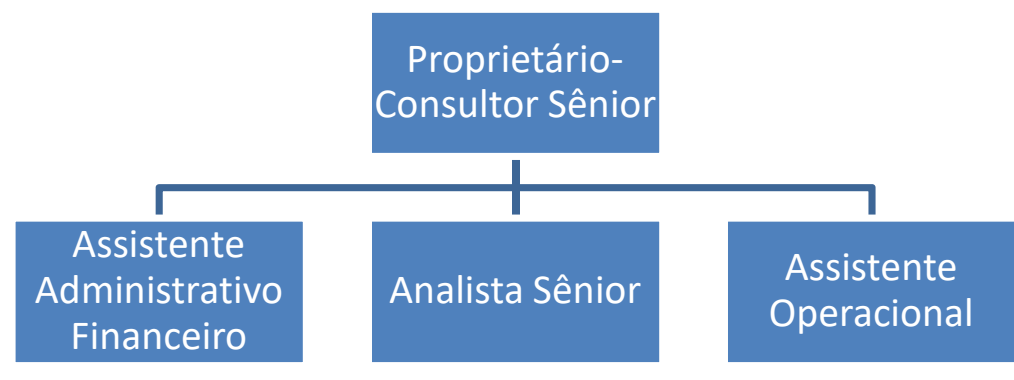

Fonte: Autoria própria (2018).

O seu portfólio de serviços é amplo e genérico e não há nenhuma segmentação por setor da economia.

Apresenta um alto índice de retenção (clientes renovam ou compram outros projetos) e de fidelização (clientes indicam outros clientes), porém apresenta dificuldades em termos de crescimento e eficiência.

Entende-se crescimento pelo próprio faturamento bruto gerado na estrutura. Esta temse elevado historicamente, porém aquém do esperado pelos sócios, não atingindo um ganho de escala.

Por eficiência entende-se o conceito de resultado versus recursos empregados. No cenário atual classifica-se tal estrutura como ineficiente pois o resultado observado é abaixo do esperado com os recursos empregados. Os recursos empregados são:

- Financeiros: investimento realizado na estrutura física da empresa (mobiliário, computadores, veículo, capital de giro) e intelectual (recursos humanos);

- Recursos Humanos: um consultor sênior, analista e assistentes; 
- Tempo: tempo de execução de projetos, tempo de prospecção de novos clientes, tempo de desenho de novas estratégias, tempo na busca de novos conhecimentos.

A seguir são apresentados alguns exemplos práticos que denotam alguns dos sintomas relacionados à dificuldade de crescimento ou esgotamento do método de trabalho:

- Um cliente de porte pequeno da região de Campinas/SP que trabalha com representação comercial contatou a DHoffmann para realização de diagnóstico de seu fluxo de caixa. A proposta foi elaborada, apresentada e aprovada. O trabalho foi executado com mais horas que o previsto e as análises e materiais finais realizados muito próximos da entrega. O trabalho final foi muito bem avaliado, porém a lucratividade foi abaixo do esperado e não existiu planejamento prévio para abordagem posterior à entrega. Para este cliente não foi executado mais nenhum trabalho. Denotou-se, de certa forma, baixo nível de padronização da entrega;

- Outro cliente na região de Osasco/SP de porte pequeno e que trabalha no segmento de artefatos infantis. O serviço contratado foi de diagnóstico amplo de gestão, com intuito de mostrar viabilidade do empreendimento e formas de crescimento. Pelo porte pequeno a verba destinada a consultoria era mínima e a DHoffmann aceitou realizar este trabalho a distância (por meios eletrônicos como Skype) e utilizar o assistente operacional (no papel de consultor júnior) para ser o contato do projeto. O diagnóstico foi realizado demonstrando viabilidade positiva, porém o assistente não conseguiu realizar os contatos com autonomia e este papel retornou ao consultor sênior, sobrecarregando-o. O trabalho foi interrompido por questão financeira do cliente. Denotou-se, de certa forma, o gargalo em recursos humanos habilitados;

- Um pequeno prospect de Campinas/SP do segmento de varejo solicitou uma visita. Neste encontro, a DHoffmann verificou necessidade de melhorias em seu planejamento comercial. A proposta comercial da DHoffmann para o prospect foi enviada com atraso e o cliente não fechou a proposta. Denotou-se, de certa forma, o posicionamento sem clareza quanto a postura comercial.

Além dos sintomas captados pelos exemplos citados cima, outros foram mapeados a partir de conversas entre sócios e funcionários, em que há, inclusive correlação com os exemplos práticos anteriores. Desta forma, realizou-se um agrupamento de sintomas ou restrições ao crescimento identificados pela própria equipe, que culminou em um gráfico 
seguindo o modelo conhecido como diagrama de Ishikawa, que é o diagrama de causa-efeito utilizado para identificação de problemas idealizado dentre as técnicas de qualidade total (ISHIKAWA, 1993). À direita do diagrama (que tem formato de uma espinha de peixe) é deixado explícito o problema em questão, nas hastes são citadas as diversas causas deste problema, e cada haste contém um nome, sendo esse um agrupamento das causas citadas. Os sintomas ou restrições ao crescimento identificados são:

- Recursos limitados (trata-se de uma organização em transição entre micro e pequena empresa, na fase de crescimento em seu ciclo de vida):

- Um consultor disponível e outro em formação: a capacidade operacional atual se dá pela quantidade disponível de horas de execução, pela especificidade do serviço;

- O consultor exerce múltiplas funções: também é sócio e gestor do negócio;

- Há dependência excessiva do consultor (centralização de atividades): para realizar etapas em clientes (fora do escritório), prospectar, apresentar propostas comerciais, realizar análises específicas;

- Recursos humanos limitados de suporte operacional aos projetos: um analista e um assistente;

- Uso de rede de parceiros não totalmente explorada: o uso de recursos humanos terceirizados como um braço operacional (recurso excedente que pode ser alocado em serviços) não é amplamente explorado.

- Baixo nível de padronização:

- Alto grau de customização dos serviços: muitos serviços executados de forma customizada mesmo que a natureza dos projetos anteriores apresente similaridades. Muitas vezes se entrega mais do que esperado ao cliente, gerando desperdício de tempo. Os aprendizados nos serviços executados não estão se tornando métodos formais, padronizados e otimizados de trabalho;

○ Processos não formalizados ou não definidos: os processos operacionais dos serviços não são formalizados ou otimizados, deixando o método de trabalho ineficiente e gerando retrabalho. Assim como os processos de suporte ao gerenciamento empresarial;

- Uso não intensivo da tecnologia: não se utiliza de recursos tecnológicos para automação de processos repetitivos, para otimização dos serviços executados. 
- Posicionamento sem clareza:

○ Venda em várias modalidades (projetos de consultoria, assessoria empresarial, horas alocadas - cursos, produtos de terceiros): não há definição clara se trata-se de uma consultoria ou assessoria ou ambas. A oferta de produtos de terceiros (parceiros de negócio) é realizada por oportunidade e não está muitas vezes conectada à estratégia empresarial;

○ Portfólio sem grande evolução (baixo nível de inovação em serviços): o portfólio de serviços não evoluiu muito desde a fundação da empresa;

- Precificação não constante: alterações na política de preços conforme oscilação da demanda;

- Estratégia não clara: a falta de uma estratégia clara e comunicada a todos faz com que as ações não sejam eficientes, sendo desconexas entre si.

O diagrama de causa-efeito, ou diagrama de Ishikawa (Fig. 3), para a DHoffmann Consultoria foi explicitado conforme a seguir:

Figura 3 - Diagrama de Causa-Efeito adaptado

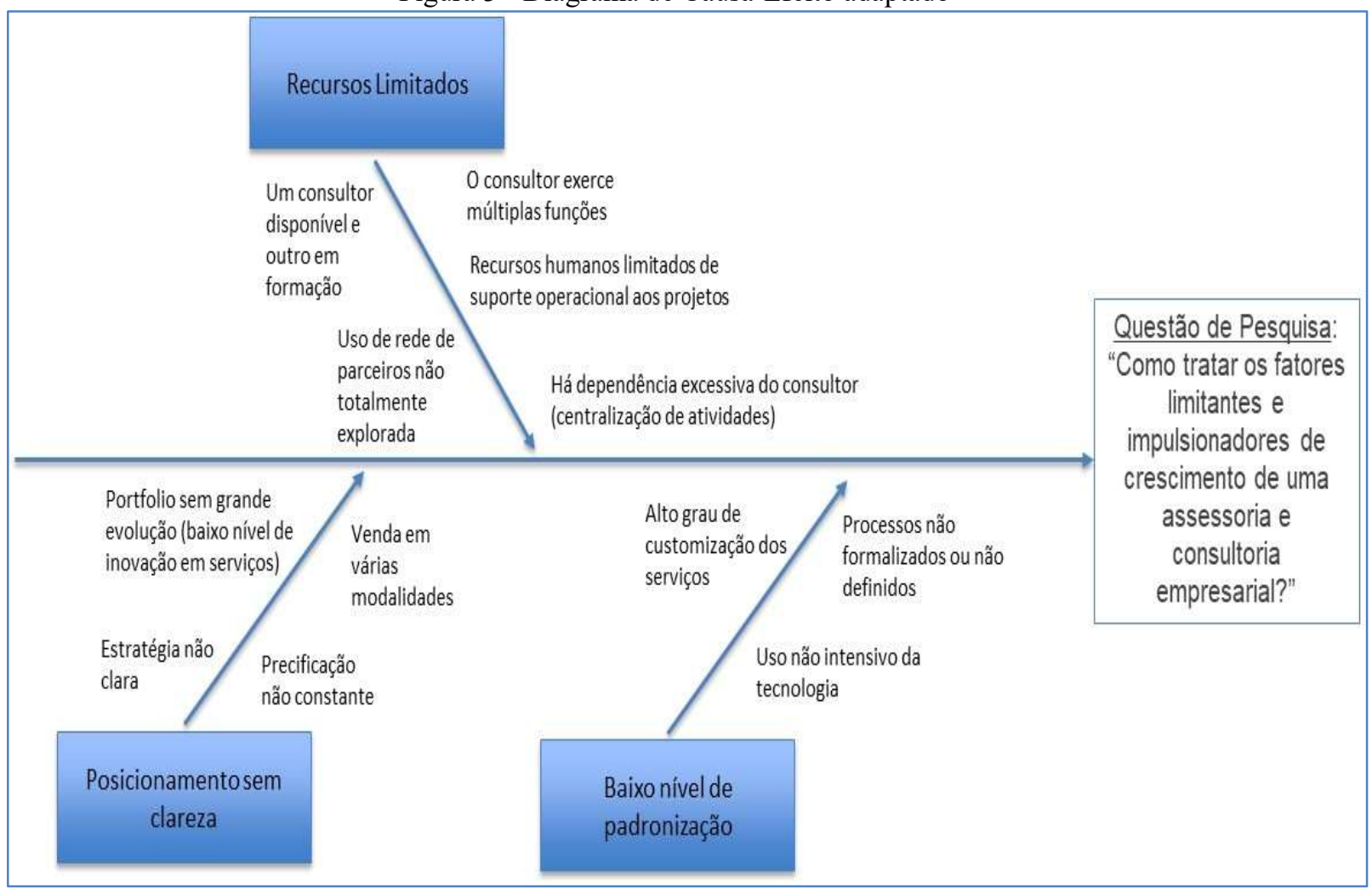

Fonte: Autoria própria (2017). 
Desta forma, o problema identificado gira em torno da dificuldade de crescimento desta organização a fim de obter ganhos de escala e possui algumas possíveis causas identificadas.

\subsection{Questão de pesquisa}

Portanto, a questão desta pesquisa é: 'Como tratar os fatores limitantes e impulsionadores de crescimento de uma consultoria e assessoria empresarial'.

\subsection{Objetivo principal e secundários da pesquisa}

O objetivo principal desta dissertação se resume a 'Propor uma sistematização das iniciativas que irão suplantar as limitações identificadas e possibilitarão o crescimento da consultoria e assessoria empresarial de pequeno porte'.

E os objetivos secundários são:

- Identificar os fatores limitantes e impulsionadores de crescimento nas referências bibliográficas, assim como soluções para o crescimento;

- Pesquisar melhores práticas para crescimento existentes em consultorias ou assessorias empresariais.

\subsection{Justificativa da pesquisa}

Primeiramente é importante destacar que esta pesquisa ocorre dentro de um programa de Mestrado Profissional em Empreendedorismo. O Método de Pesquisa Profissional é uma ferramenta que orienta o pesquisador a desenvolver sua pesquisa partindo da sua prática profissional, como no caso desta dissertação. Posterior à identificação do problema, o pesquisador busca embasamento teórico suficiente para complementar com achados de campo utilizando-se de diversos métodos e instrumentos para estudar a solução do problema (ALMEIDA et al., 2019). Portanto, os achados desta pesquisa se relacionam a um problema prático vivenciado pelo próprio pesquisador e também por outros empresários brasileiros.

O problema explicitado nesta dissertação, a dificuldade em crescer e ganhar escala em uma empresa de pequeno porte (no caso desta dissertação uma prestadora de serviços consultoria e assessoria empresarial), é vivenciado pelas empresas em seu ciclo de vida (SCOTT et al, 1987). As empresas nascem, crescem, amadurecem e morrem ou se 
reinventam, iniciando um novo ciclo. Pelas particularidades das pequenas empresas, principalmente quanto às suas restrições de recursos, o tema crescimento é de extrema importância e altamente relevante pois se relaciona com a própria sobrevivência da organização e, consequentemente, com as pessoas que fazem parte dela (sócios e funcionários).

Por meio dos achados desta pesquisa, com o conhecimento dos limitadores do crescimento organizacional, os seus impulsionadores e como tratá-los, espera-se que haja contribuição aos empresários e aspirantes nas tratativas práticas em relação ao tema exposto.

\subsection{Estrutura da Dissertação}

Esta dissertação contará com capítulos encadeados e ordenados a fím de respeitar o método profissional de pesquisa, promovendo a relação entre a prática e a teoria, para responder à questão de pesquisa atingindo os objetivos explícitos neste material. A estrutura seguirá conforme apresentado na Figura 4:

Figura 4 - Estrutura da Dissertação

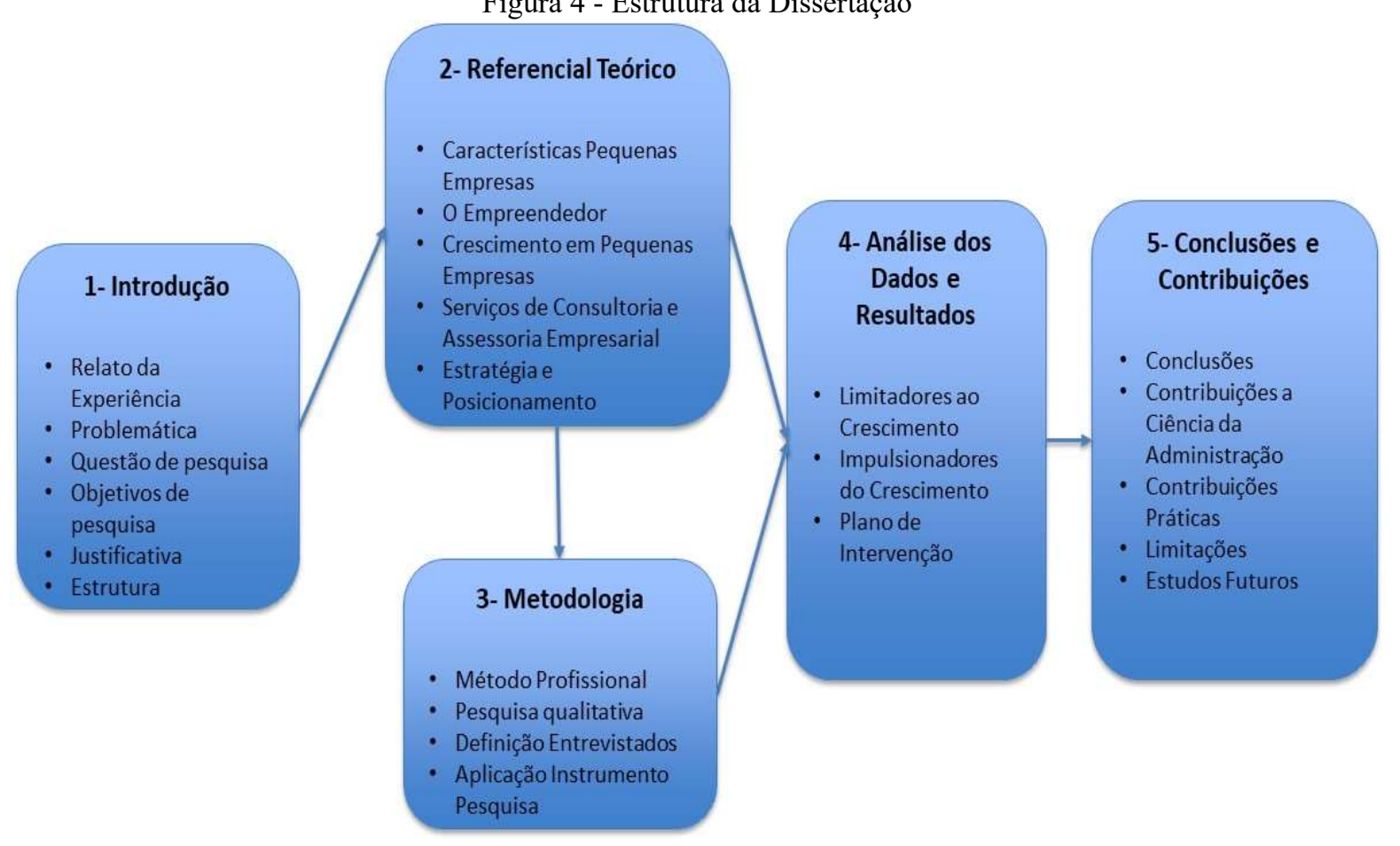

Fonte: Autoria própria (2018).

O primeiro capítulo, denominado introdução, traz o contexto por detrás do relato da experiência do pesquisador, fatos e dados correlacionados ao objeto de pesquisa em questão. 
No relato da experiência, o autor explora o próprio objeto de pesquisa, a organização em que foi identificado o problema de pesquisa, sua história e evolução. A problemática é tratada em seguida, o problema é identificado na prática, com exemplos e situações vivenciadas. Finalmente a questão de pesquisa é exposta assim como os seus objetivos, principal e secundários. Neste capítulo discorre-se sobre a experiência prática do autor, decorrente de sua vivência em sua empresa, determinar com clareza o problema vivenciado e abrir a grande pergunta de pesquisa, assim como onde se espera chegar com esta dissertação. A relação entre a determinação do problema (de origem prática) e o objetivo desta pesquisa é evidenciada.

No segundo capítulo, sob o título de referencial teórico, foram evidenciadas as teorias de administração correlacionadas à problemática e aos objetivos de pesquisa citados no primeiro capítulo. Esta pesquisa bibliográfica percorreu temas como: particularidades das pequenas empresas, ciclo de vida de uma pequena empresa, alavancas de crescimento para uma pequena empresa, serviço de consultoria e estratégia. Estes tópicos suportaram parte dos elementos correlacionados ao problema evidenciado.

O terceiro capítulo, metodologia, explicita quais métodos e instrumentos de pesquisa foram utilizados nesta pesquisa, dentro do método profissional. Trata-se de como a pesquisa foi elaborada e quais elementos usados na prática.

Na sequência, no capítulo quatro, denominado Análise de Dados e Resultados, é detalhada a amostragem utilizada nesta pesquisa (suas características), os resultados das entrevistas são explorados com profundidade e há a ocorrência de triangulação metodológica.

Por fim, no capítulo cinco, denominado Conclusões e Contribuições, são apresentados e discutidos os resultados, direcionadas as conclusões, recomendações e considerações finais da pesquisa, suas contribuições e limitações, bem como sugestões de estudos futuros em pesquisas do gênero. É sugerida uma sistematização (a fim de buscar solução ao problema evidenciado) e esta comparada com o referencial prático e teórico coletado. 


\section{REFERENCIAL TEÓRICO}

As referências teóricas, no campo da ciência da administração, devem apoiar a seleção de conhecimento coerente e oportuno para suportar a confecção da resposta à questão da pesquisa e atendimento dos objetivos desta. Os achados devem somar aos achados da pesquisa de campo e, conjuntamente, apoiar a conclusão desta pesquisa.

Por se tratar de um método de pesquisa profissional e a problemática apresentada remeter a diversas causas, como apresentado no diagrama do capítulo anterior, se faz necessária a busca de múltiplas fontes de dados, de forma abrangente, sobre os temas apresentados. Esta abordagem sistêmica influencia a fundamentação teórica para uma pesquisa profissional (ALMEIDA et al., 2019).

Este capítulo visa atender ao primeiro objetivo secundário explicitado anteriormente, identificar os fatores limitantes e impulsionadores de crescimento nas referências bibliográficas, assim como soluções para o crescimento.

Portanto, para atender ao primeiro objetivo e abordar as áreas de conhecimento necessárias para cobrir o problema apresentado, foi construída uma matriz relacionando os problemas identificados e suas causas (diagrama apresentado) e as áreas de conhecimento referenciadas neste material. A matriz está explicitada na Figura 5 e o conteúdo elencado na sequência deste capítulo.

Figura 5 - Matriz Objetivos e Teoria Estudada

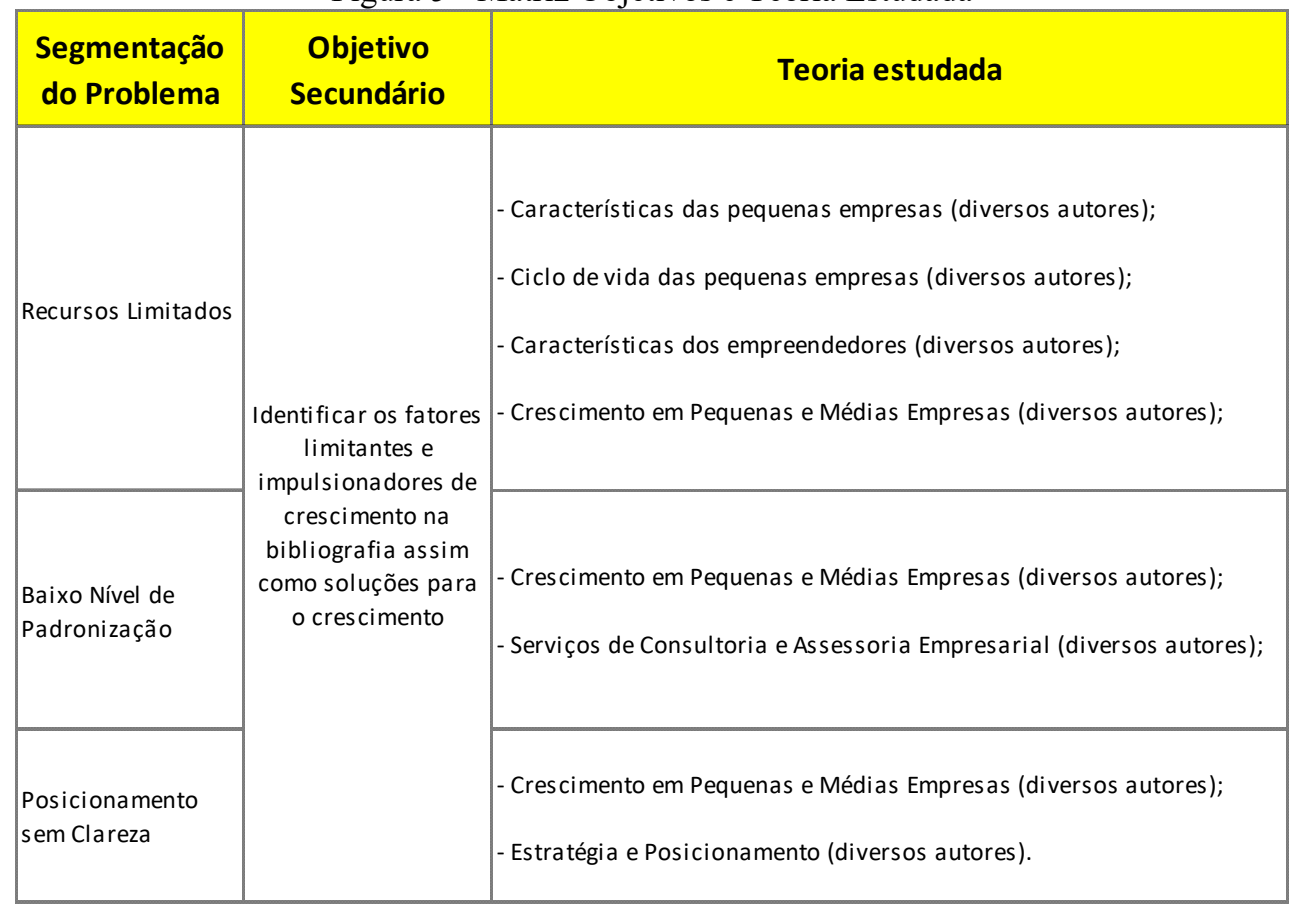

Fonte: Autoria própria (2018) 


\subsection{A Pequena Empresa, características, especificidades e ciclo de vida}

\subsubsection{A Pequena Empresa, características e especificidades}

Existem diversos motivos pelos quais uma pessoa decide abrir um negócio próprio. Alguns estudiosos levantaram alguns agrupamentos que explicam estes motivadores.

Os motivos que levam os empreendedores a abrirem um negócio próprio são, em ordem de importância: Identificar uma oportunidade de negócio; ter experiência anterior; estar desempregado; ter tempo disponível; dispor de capital; estar insatisfeito no emprego; ter sido demitido e recebido indenização (TACHIZAWA; FARIA, 2004).

Portanto, as motivações que levam ao empreendedorismo, no sentido de abertura de novos empreendimentos (negócios), podem ser de ordem pessoal ou material. Ou podem ser relacionadas ao empreendedorismo por necessidade ou por oportunidade (LEMES JÚNIOR; PISA, 2010).

As motivações pessoais compreendem: tradição familiar, colocar conhecimentos adquiridos em prática, necessidade de autorrealização profissional, necessidade de reconhecimento social (status), contribuir para o desenvolvimento social e necessidade de ser o seu próprio chefe (LEMES JÚNIOR; PISA, 2010).

As motivações materiais compreendem: ganhar dinheiro (aumentar renda ou ficar rico), disponibilidade de recursos, desemprego, visualização de oportunidade inovadora, existência de órgão de apoio e financiamento e mercado aquecido (LEMES JÚNIOR; PISA, 2010).

Independente da motivação para abrir um negócio, esta organização possuirá algumas características e passará por alguns desafios caso deseje sobreviver e crescer.

Porém é necessário obter o correto entendimento de quais são estas características para classificarmos uma empresa como micro ou pequena, dentro do Brasil.

Oficialmente, no Brasil, segundo a Lei Geral das Microempresas e Empresas de Pequeno Porte de 2006, as empresas são classificadas em seu porte seguindo faixas de faturamento bruto (SEBRAE, 2018):

- Microempreendedor individual: indivíduo que trabalha sozinho e legalizado, com receita bruta anual de até $\mathrm{R} \$ 81.000,00$. O microempreendedor pode possuir um único empregado e não pode ser sócio ou titular de outra empresa;

- Microempresa: sociedade empresária com a receita bruta igual ou inferior a $\mathrm{R} \$$ $360.000,00$; 
- Empresa de pequeno porte: se a receita bruta anual for superior a $\mathrm{R} \$ 360.000,00 \mathrm{e}$ igual ou inferior a $\mathrm{R} \$ 4.800 .000,00$.

Também existe uma classificação segundo o Sebrae/Dieese (Fig. 6), incluindo o fator número de funcionários para classificar as empresas.

Figura 6 - Porte Empresa por Número de Funcionários

Definiçăo de porte de estabelecimentos segundo o número de empregados

\begin{tabular}{|l|c|c|}
\hline Porte & Comércio e Serviços & Indústria \\
\hline Microempresa (ME) & Até 9 empregados & Até 19 empregados \\
\hline Empresa de Pequeno Porte (EPP) & De 10 a 49 empregados & De 20 a 99 empregados \\
\hline Empresa de médio porte & De 50 a 99 empregados & De 100 a 499 empregados \\
\hline Grandes empresas & 100 ou mais empregados & 500 ou mais empregados \\
\hline
\end{tabular}

Fonte: SEBRAE-NA/ Dieese. Anuário do trabalho na micro e pequena empresa (2013, p. 17).

Para efeito desta pesquisa, juntamente com seu orientador, o pesquisador utilizou o livre conceito de empresa de pequeno porte, sendo o seguinte: tem como característica marcante a atuação empresarial estar amplamente centrada em seu proprietário-executor e fisicamente em sua residência.

As pequenas empresas possuem características particulares e distintas das grandes organizações (TERENCE, 2008). Algumas características de ordem organizacional são evidenciadas por: estrutura simples, centralizadas, necessitam de uma quantidade menor de funções administrativas, têm nível de maturidade baixo, e gestão personalizada pelo dirigente. Outras características dizem respeito ao processo decisório: decisões tomadas a partir da experiência ou intuição do dirigente, normalmente de curto prazo. As demais características são individuais: onde um só indivíduo tem papel dominante, o proprietário-dirigente, que é paternalista, intuito e centralizador (TERENCE, 2008).

Os condicionantes ambientais, os organizacionais e os comportamentais do dirigente da pequena empresa podem ter como consequência a concorrência desigual com as grandes empresas; o grande poder de barganha dos clientes e fornecedores da empresa; o pouco ou nenhum poder de influência perante as imposições e mudanças do Macroambiente; a estrutura organizacional não formalizada e reduzida; a falta de pessoas qualificadas; a escassez de recursos financeiros e materiais; a não utilização de instrumentos administrativos formais; a 
informalidade no relacionamento; e a falta de habilidade na gestão do tempo, de acordo com (CÊRA; ESCRIVÃO FILHO, 2003).

As pequenas empresas podem também seguir com estruturas familiares. Estas reúnem características próprias. Gersick et al. (1997) criaram o modelo de 3 círculos, no qual classificam a gestão familiar em três sistemas independentes e relacionados: Gestão, Família e Propriedade. A Figura 7 demonstra o conceito:

Figura 7- Modelo de Três Círculos da Empresa Familiar

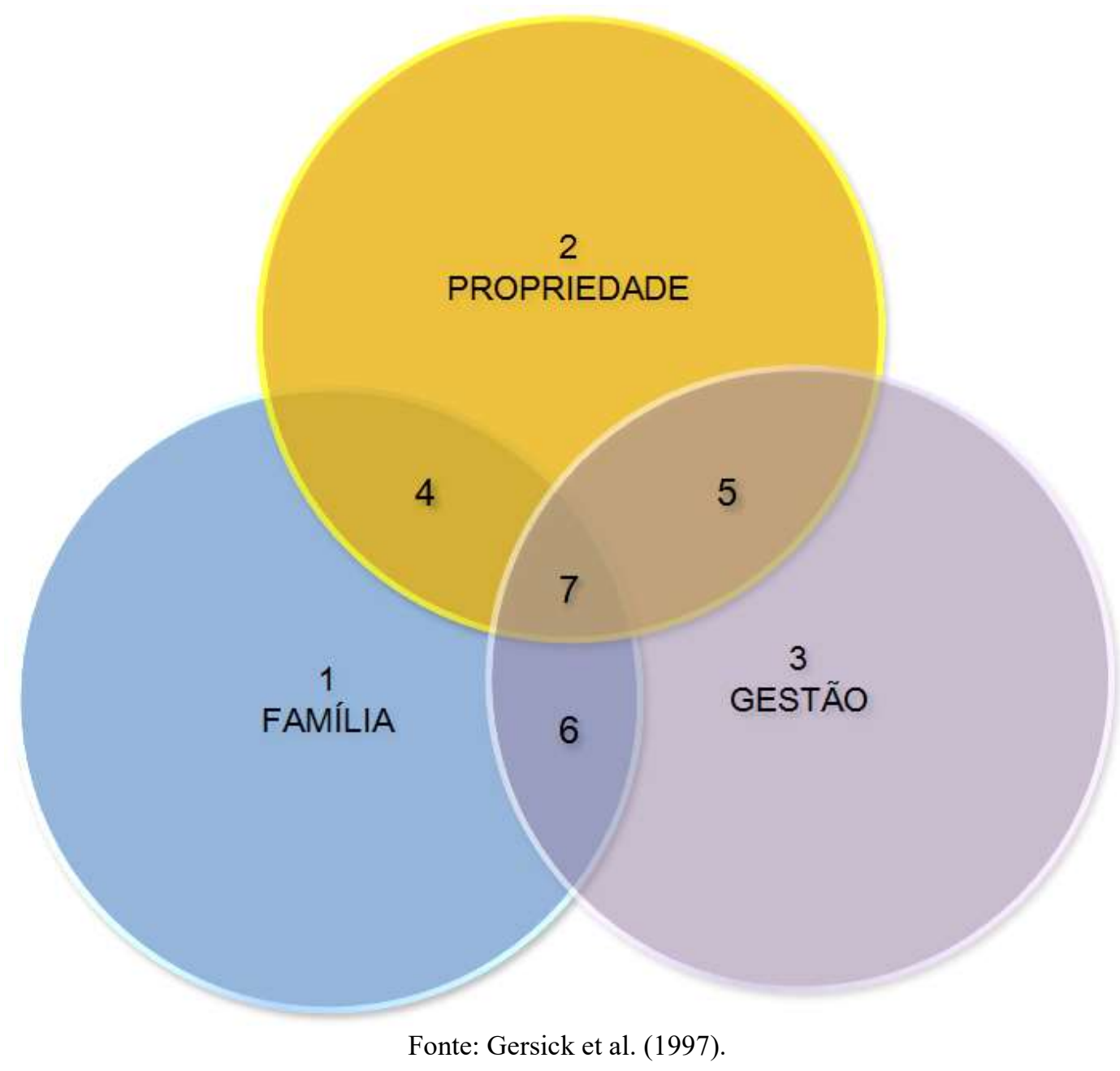

Identificam-se no modelo 7 intersecções, chamadas de setores:

1. Membro da Família, que não é proprietário, nem funcionário;

2. Acionista, que não é membro da família nem funcionário;

3. Funcionário, que não é proprietário nem membro da família;

4. Proprietário, que é membro da família, mas não trabalha na empresa;

5. Proprietário, que trabalha na empresa, mas não é membro da família; 
6. Membro da família, que é funcionário, mas não é proprietário;

7. Proprietário, que é membro da família e trabalha na empresa.

Dentro do conceito, ao situar as pessoas pertencentes a uma empresa familiar num dos sete setores é possível compreender como cada uma vê e sente a organização, ou seja, o tamanho do interesse e do comprometimento (maior ou menor) de cada pessoa, dentro do papel que desempenha. Isto gera complexidade à administração de um negócio familiar, mesmo sendo uma pequena empresa (GERSICK et al, 1997).

Petry e Nascimento (2009) fazem um interessante apanhado de diversos autores e apontam as principais falhas encontradas entre empresas familiares do Rio Grande do Sul pesquisadas em seu arquivo referenciado:

a) centralização de poder pelo fundador;

b) emprego e promoção indiscriminada de familiares por favorecimento em detrimento do conhecimento e da competência profissionais;

c) ausência de metas e objetivos claros;

d) resistência no estabelecimento de controles gerenciais formais;

e) sistemas de planejamento estratégico e operacional frágeis ou inexistentes;

f) inexistência ou fragilidade de sistemas contábeis e de apuração de custos;

g) composição societária familiar quantitativa em crescimento exponencial.

Outras estruturas, ainda que não familiares, encontram problemas típicos de pequenas empresas. O artigo de Oliveira e Melhado (2008), embora direcionado a empresas de projetos de edifícios, enumera limitantes de desempenho encontrados na gestão de empresas desse segmento que são extrapolados pelos autores para as pequenas empresas em geral: recursos financeiros, humanos e tecnológicos escassos; alta dependência do grau de empreendedorismo e liderança de seus titulares; seus proprietários atuam tanto na gestão técnica como administrativa e, em geral, desconhecem as principais técnicas de gestão disponíveis.

Oliveira e Melhado (2008) citam ainda Schel (1995), que enumera as seguintes características para pequenas empresas, além do reduzido número de empregados:

a) Estrutura organizacional simples com poucos níveis hierárquicos e uma grande concentração de autoridade;

b) Ocupa um espaço bem-definido no mercado em que atua;

c) Possui flexibilidade locacional, espalhando-se por todo o território nacional e desempenhando importante papel na interiorização do desenvolvimento; 
d) Possui maior intensidade de trabalho;

e) O proprietário e a administração são altamente interdependentes, ou seja, em geral não há diferença entre os assuntos particulares e empresariais, pois é comum o empreendedor utilizar-se da mesma conta bancária de sua empresa;

f) Existe predominância absoluta do capital privado nacional.

Para resumir e levar para esta pesquisa os achados na teoria, tem-se que as organizações de pequeno porte possuem características que talvez restrinjam ou dificultem o crescimento da organização. Pode-se tratar das restrições de recursos financeiros e humanos, centralização do poder e multidisciplinariedade do proprietário e ineficiência do sistema de gestão. Além disto, trazendo o livre conceito de microempresa utilizado nesta pesquisa, o proprietário prestar o serviço sozinho e fisicamente em sua própria residência. Tais características, provavelmente, exijam do proprietário um foco em eficiência e disposição à mudança para criar uma organização passível de crescimento. Relacionando com a empresa em que o pesquisador é proprietário, estas características são bem marcantes. A restrição de recursos, inclusive, foi citada como uma das causas da limitação do crescimento.

\subsubsection{Ciclo de vida da Pequena Empresa}

As organizações, como sistemas, seguem uma lógica de crescimento. Têm o seu início, crescem, entram na maturidade, morrem ou inovam, ou seja, iniciam um novo ciclo.

Como resultado de pesquisas, foram identificadas certas fases de crescimento para pequenas empresas, padrões existentes em casa fase e crises anteriores ou posteriores que impactam cada fase.

Segundo Scott e Bruce, autores de um estudo específico para ciclo de vida para pequenas empresas, para este tipo de organização existem cinco estágios de crescimento, descritos como Inicial; Sobrevivência; Crescimento; Expansão e Maturidade, conforme gráfico (Fig. 8) abaixo: 
Figura 8 - Ciclo de vida de uma pequena empresa

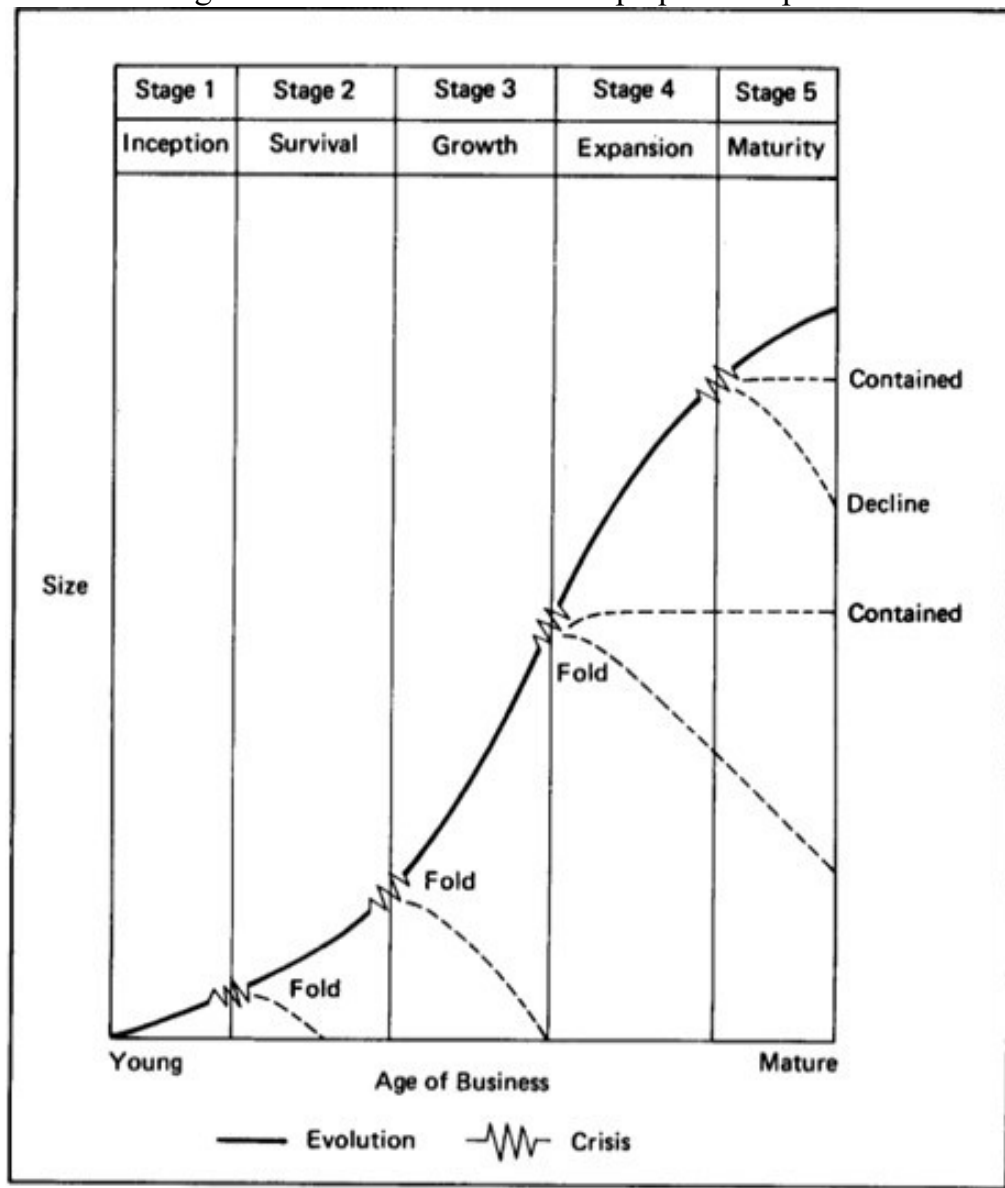

Fonte: Scott e Bruce (1987).

Para a fase inicial, o item mais importante é estabelecer o produto que seja comercialmente aceito, ou seja, aderente ao mercado e com vendas realizadas. Normalmente há grande centralização no fundador e poucos canais de distribuição desenvolvidos. Algumas crises podem acontecer neste estágio e atrapalhar a evolução da organização, são elas: enfatizar a lucratividade a qualquer custo, ou as demandas administrativas crescerem desproporcionalmente. Caso alguma destas crises persista a organização terá muita dificuldade para percorrer a próxima etapa.

A próxima etapa diz respeito à sobrevivência, em que o produto já é aceito comercialmente e o desafio se altera para o financiamento da própria expansão, com maiores estoques (quando o é utilizado) e volumes a receber de clientes. Trata-se, portanto, de uma fase com crescimento em vendas e, consequentemente, do capital de giro associado. As crises nesta fase podem ser: financiar mais que o devido, aumento da complexidade dos canais de distribuição, aumento da competição com impacto em preço e pressões por informação. Caso alguma destas crises persista a organização terá muita dificuldade para percorrer a próxima etapa. 
A fase de crescimento se caracteriza pela existência de uma organização lucrativa, porém com necessidade de grandes investimentos em capital de giro e ainda uma estrutura mais formal para suportar tal crescimento. As crises desta fase podem ser: possibilidade de entrada de grandes concorrentes trabalhando baixo preço e ter equilíbrio entre investimentos financeiros e controle operacional. Caso alguma destas crises persista a organização terá muita dificuldade para percorrer a próxima etapa.

Como um achado para esta pesquisa é interessante notar que as crises e a posterior evolução de fase dizem respeito ao equilíbrio entre investimento financeiro (ou como lidar com os recursos disponíveis) e estrutura organizacional (e de gestão) que suporte tal crescimento. Ou seja, o como equilibrar a eficiência no uso dos recursos disponíveis para criar um ambiente competitivo e com controle para suportar tal crescimento. Importante notar também que o papel do fundador (proprietário) se altera ao longo dos ciclos, denotando que seu comportamento deve ser situacional, ou seja, se alterar ao longo das fases. Se foi visto no tópico anterior que as características da pequena empresa poderiam ser restrições ao crescimento, tais como restrições de recursos financeiros e humanos, centralização do poder e multidisciplinariedade do proprietário e ineficiência do sistema de gestão, é evidenciado agora que o modo ou a forma de lidar com estas restrições faz com que a organização evolua em seu ciclo de vida, chegando à fase de crescimento. Portanto, tem-se que alguns impulsionadores de crescimento estejam ligados à forma de lidar com as próprias características das pequenas empresas. Na própria empresa do pesquisador é notável a diferença e os desafios das fases iniciais, neste momento situando-se na fase de crescimento em que o desafio é ter o equilíbrio entre o aumento dos gastos (contratação de recursos humanos habilitados e ampliação da estrutura física), limitação de capacidade operacional (tempo para entrega de projetos e assessoria) e retorno financeiro (manter boa lucratividade).

\subsection{O Empreendedor}

Como visto no item anterior, a forma de lidar com os recursos disponíveis e limitados na pequena empresa faz com que a organização evolua em seu ciclo de vida. Dado que entre as características de uma pequena organização encontra-se a centralização do poder e papel predominante do proprietário, o comportamento deste e sua mudança ao longo dos ciclos deve ser fundamental ao crescimento da empresa. Para esta pesquisa pode-se utilizar como sinônimos do termo proprietário de uma pequena empresa os seguintes termos: empreendedor, empresário, dirigente, dono. 
Existem diversos conceitos a respeito do empreendedor. Identificar, selecionar e transformar as oportunidades de negócio em negócios efetivamente são atributos do indivíduo chamado empreendedor. Suas características principais são: ter visão das oportunidades, ter força de vontade para criar, criar novas utilizações para velhas ideias e capacidade de aprimorar processos e produtos (LEMES JÚNIOR; PISA, 2010).

Ser empreendedor é ser aquele capaz de visualizar uma realização futura e, através do seu trabalho e de próprios recursos, combinado com trabalho e recursos de terceiros, torná-la realidade. Ele vai além, condicionando o desenvolvimento econômico ao processo de empreendedorismo (SCHUMPETER, 1934).

Outra definição trata o empreendedor como um indivíduo capaz de identificar oportunidades, criar uma organização para administrar recursos a fim de explorar esta oportunidade identificada, e que assume risco sendo quotista desta organização (DRUCKER, 2002).

A imaginação e o poder da criação, através do desenvolvimento de visões (somatória de um objetivo concreto e o que deve ser feito), também são características dos empreendedores (FILION, 1991).

$\mathrm{O}$ ato de descobrir necessidades do mercado e abrir novas empresas para satisfazer estas necessidades são atitudes do empreendedor (LONGENECKER et al, 2013).

Segundo os conceitos citados anteriormente, o empreendedor é um indivíduo mais voltado a ter ideias, à imaginação, à visão de algo que pode ser aplicado, ou seja, a uma oportunidade que pode virar um negócio. Porém, um negócio depende também de sua administração (como será gerenciado) e da execução de todas as atividades associadas ao negócio.

Segundo Gerber (2011), o indivíduo que abre um negócio possui, ou deve possuir, três personalidades (ou capacidades), que podemos entender também como papéis ou funções distintas: empreendedora, administradora e a técnica.

A personalidade empreendedora se relaciona com a capacidade de visão.

\footnotetext{
A personalidade empreendedora transforma a condição mais trivial em oportunidade excepcional. O Empreendedor vive no futuro; nunca no passado e raras vezes no presente. Sua maior felicidade é sentir-se livre para construir imagens de conjecturas e hipóteses. Toda personalidade fortemente empreendedora sente uma necessidade extraordinária de mandar. Já que vive no mundo imaginário do futuro, precisa controlar pessoas e fatos do presente, para concentrar-se em seus sonhos. Para o Empreendedor, as pessoas, em sua maioria, são obstáculos no caminho da realização de seu sonho (GERBER, 2011).
} 
A personalidade administradora se relaciona com a capacidade de organização.

A personalidade administradora é pragmática. Sem o administrador, não haveria planejamento, ordem nem previsibilidade. Se o empreendedor vive no futuro, o administrador vive no passado. Enquanto o empreendedor invariavelmente percebe a oportunidade nos acontecimentos, o administrador sempre enxerga os problemas. Sem o administrador, não haveria empresas nem sociedade. Sem o empreendedor, não haveria inovação (GERBER, 2011).

A personalidade técnica se relaciona com a capacidade de execução.

O técnico é gente que faz. Se o empreendedor vive no futuro, e o administrador, no passado, o técnico vive no presente. Ele gosta de ter o que fazer e de saber que as tarefas podem ser cumpridas. O técnico não se interessa por ideias; interessa-se pelo modo de fazer. O técnico sabe que, se não fosse por ele, haveria muita gente pensando e ninguém realizando. O técnico é fortemente individualista (GERBER, 2011).

Segundo Gerber (2011), o indivíduo que abre um negócio deve ser empreendedor, administrador e técnico, ou a própria organização deve ter estas competências desenvolvidas para o êxito do empreendimento. Ou seja, tais comportamentos são premissas básicas para a organização evoluir, ou seja, crescer (GERBER, 2011).

\begin{abstract}
A verdade é que todos têm dentro de si um empreendedor, um administrador e um técnico. E, se os três forem bem equilibrados, estaremos diante de um indivíduo muito competente. Infelizmente, nossa experiência demonstra que, entre os que chegam ao mundo dos negócios, poucos são abençoados com tal equilíbrio. $\mathrm{O}$ pequeno empresário típico é $10 \%$ empreendedor, $20 \%$ administrador e $70 \%$ técnico. Em resumo, você vai encontrar o empreendedor nos sonhos e planos, o administrador nas tentativas de deixar tudo como está e o técnico nas atitudes que enlouquecem os outros dois (GERBER, 2011).
\end{abstract}

É fato que os termos empreendedorismo e empreendedor são utilizados em larga escala atualmente, porém empreendedor e gestor de empresas não são sinônimos (LONGENECKER et al., 2013). Da mesma forma como Gerber (2011) discrimina o papel do empreendedor, do administrador e do técnico.

Desta forma, entende-se que o desenvolvimento humano do proprietário é muito importante para o crescimento do negócio.

Timmons e Spinelli (2004), pesquisadores de empreendedorismo, listam características do empreendedor, agrupando em atitudes e comportamentos desejáveis e adquiríveis: comprometimento e determinação; liderança; obsessão por oportunidades; tolerância aos riscos, às ambiguidades e às incertezas; criatividade; autoconfiança, adaptabilidade e motivação para vencer. 
O Sebrae (2008) também lista as características comportamentais essenciais aos empreendedores (e que utiliza em seus treinamentos, oriundos do método desenvolvido pela ONU de desenvolvimento de competências empreendedoras): busca de oportunidades e iniciativa; persistência; correr riscos calculados; exigência de qualidade e eficiência; comprometimento; busca de informação; estabelecimento de metas, planejamento e monitoramento sistemáticos; persuasão e rede de contatos; independência, autoconfiança e necessidade de realização.

Com esta referência bibliográfica, verifica-se que o comportamento do empreendedor pode influenciar o crescimento de sua empresa. Os comportamentos citados pelo Sebrae (2008), por exemplo, são orientados à visão empresarial, eficiência na execução e boas práticas de gestão. Tem-se que tais grupos de comportamento podem ser cruciais para lidar com os limitadores de crescimento empresarial e impulsionar este crescimento.

\subsection{Crescimento em pequenas empresas}

Anteriormente foi visto que as características das pequenas empresas podem ser grandes limitadores de seu próprio crescimento, porém o comportamento do empreendedor no sentido de utilizar eficientemente os recursos disponíveis pode impulsionar tal crescimento.

Segundo estudo da consultoria Deloitte e da revista Exame, intitulado "As PMEs que mais Crescem no Brasil”" (DELOITTE; EXAME, 2016), as PMEs estudadas que cresceram possuíam alguns pilares centrais de suporte a este crescimento, são eles: continuidade dos investimentos (com foco em otimizar processos, obter ganho de produtividade e rever o portfólio de apostas estratégicas); busca por eficiência (foco no core business e revisão de processos); monitoramento de desempenho e mercado (acompanhamento constante de desempenho); governança corporativa (práticas de transparência); e foco na sustentabilidade do negócio (monitoramento do nível de endividamento empresarial).

Associada à evolução necessária no quesito boas práticas de gestão, está no cerne do ganho ou manutenção da competitividade a inovação empresarial.

“Com a evolução tecnológica no mundo dos negócios, os investimentos em inovação nas empresas emergentes devem estar alinhados às melhores práticas de governança e à busca por maior produtividade e eficiência" (DELOITTE; EXAME, 2016, pg. 6). Desta forma traz à tona os investimentos em inovação como uma importante fonte de competitividade, com um direcionador claro de investimentos em tecnologia, visando aumentar produtividade e lançar novos produtos. Associando a uma micro e pequena empresa tem-se que a prática mais 
aplicável, pelo conhecimento do pesquisador, seria a de investir em tecnologia (implantação de softwares, hardwares e equipamentos específicos para ganho de produtividade).

Figura 9 - Práticas de fomento à inovação

Práticas de fomento à inovação (em \% de respondentes; respostas múltiplas)

Investem constantemente em tecnologia

Buscam disseminar uma cultura aberta a novas perspectivas na solução de problemas

Formam profissionais capacitados a lidar com a maior diversidade possivel de desafios

Fazem parcerias com fornecedores para o desenvolvimento de produtos ou serviços

Dispõem de áreas de pesquisa e desenvolvimento Adotam uma estratégia formal de negócios que prioriza a inovação

Possuem uma política de reconhecimento de funcionários que dão ideias inovadoras

Contam com métricas para avaliar se as ideias inovadoras se refletem em negócios

\section{5}

\section{2}

64

64

54

46

35

23

Fonte: As PMEs que mais Crescem no Brasil” (DELOITTE; EXAME, 2016).

Figura 10 - PMEs e Novos Produtos e Serviços

Novos produtos e serviços

$83 \%$ das PMES

2013

lançaram novos

produtos e serviços

\begin{tabular}{|l|}
2013 \\
\hline 62 \\
2014 \\
71 \\
2015 \\
77 \\
\hline
\end{tabular}

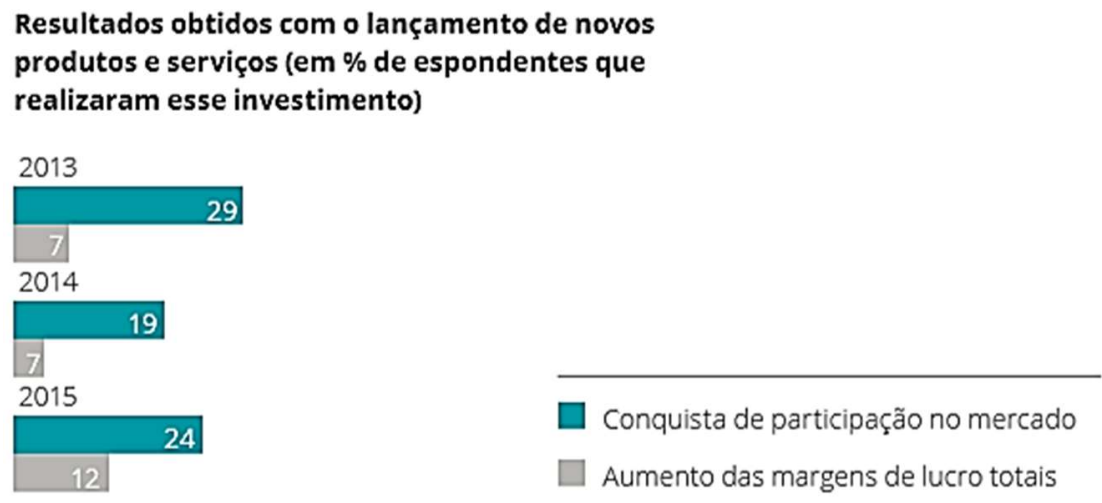

Fonte: As PMEs que mais Crescem no Brasil (DELOITTE; EXAME, 2016). 
Segundo o mesmo estudo, $75 \%$ das empresas investiram em tecnologia de software, 83\% investiram em novos equipamentos e 83\% das PMEs pesquisadas lançaram novos produtos e serviços no ciclo obtendo resultados positivos, tais como: conquista de participação de mercado e aumento das margens de lucro totais. Associa-se, então, neste ponto, a inovação, com a ampliação da produtividade e desenvolvimento de novos produtos, ao resultado positivo financeiro destas escolhas estratégicas.

Quanto as ações para busca de eficiência, ou seja, fazer a organização se tornar mais eficiente, as três ações mais utilizadas são: implantação de metas para redução de gastos, foco na atividade principal da empresa e revisão de processos e atividades internas. Existem outras ações, conforme gráfico (Fig. 11) apresentado a seguir:

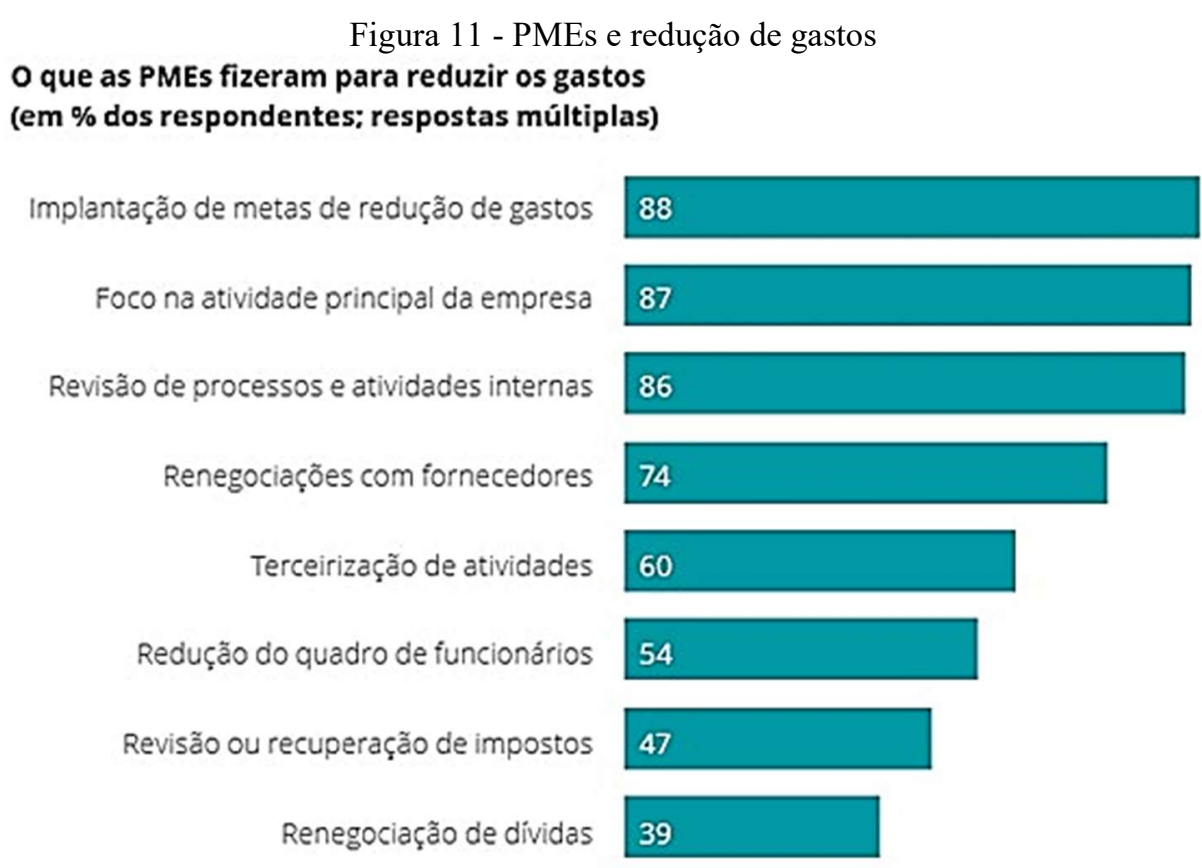

Fonte: As PMEs que mais Crescem no Brasil (DELOITTE; EXAME, 2016).

As empresas pesquisadas, quando indagadas sobre quais ações deveriam perseguir para ter manutenção do crescimento até 2020, responderam como as cinco principais: ampliar carteira de clientes, manter constantes inovações, manter bons profissionais, aumentar produtividade e ampliar o portfólio de produtos e serviços conforme segue (Fig. 12): 
Figura 12 - PMEs e Ações para manutenção de crescimento até 2020

Perspectivas

Ações para manutenção do crescimento e do sucesso até 2020

(em \% de respondentes; respostas múltiplas)

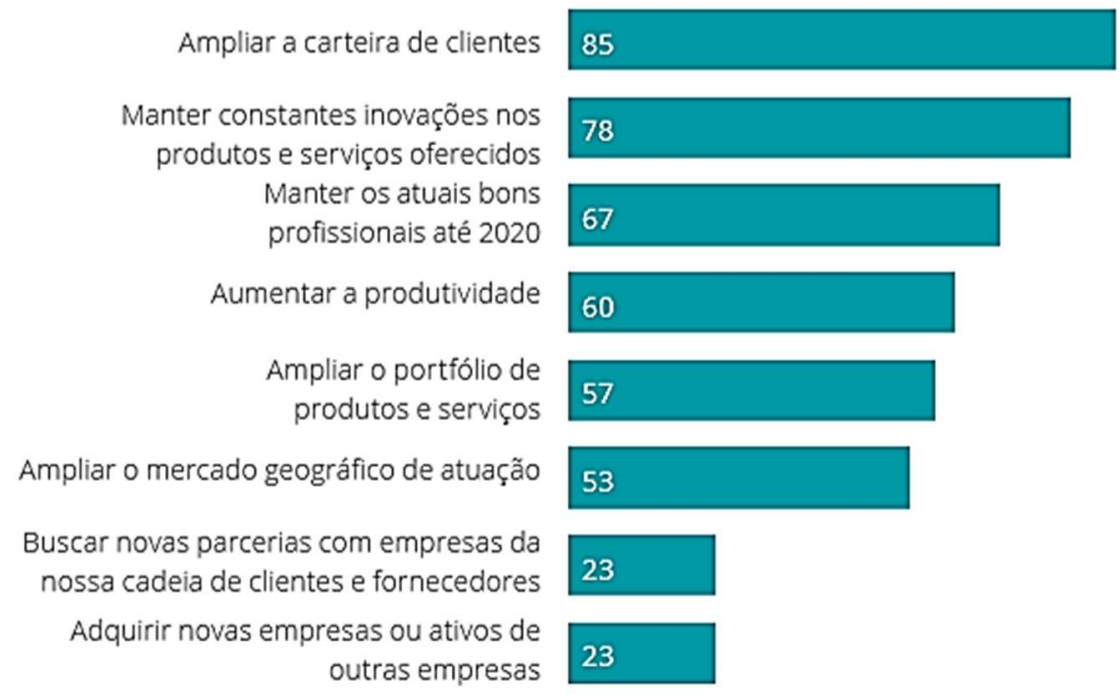

Fonte: As PMEs que mais Crescem no Brasil (DELOITTE; EXAME, 2016).

O estudo realizado pela Deloitte em parceria com a Revista Exame (2016) demonstra algumas das práticas utilizadas por PMEs brasileiras que cresceram nos últimos anos. Para esta dissertação, estas ações práticas podem ser consideradas, provavelmente, como impulsionadores do crescimento de pequenas empresas. Observando a sua própria experiência, o pesquisador relata que provavelmente os impulsionadores com mais aderência à própria realidade vivenciada seriam: investir em sistemas tecnológicos para ganho de produtividade, inovar com novos serviços e revisão de processos.

Outras ações e posicionamentos podem ser elencados como prováveis impulsionadores de crescimento empresarial. Zook e Allen, sócios da consultoria Bain \& Company, em seu livro O Poder dos Modelos Replicáveis, defendem que os negócios que crescem e se sustentam possuem algumas características em comum: core bem diferenciado (a diferenciação da oferta deve ser clara), valores e princípios claros e ter um sistema de aprendizado dinâmico (que possibilita adaptações ao mercado).

“A diferenciação é a essência da estratégia, a causa básica da vantagem competitiva e o principal vetor da lucratividade relativa entre as empresas" (ZOOK et al., 2012, pg. 16). Possuir ativos únicos e competências essenciais que criam esta diferenciação são considerados pelos autores como o "core do core" da empresa, ou seja, o cerne da vantagem competitiva. As empresas que crescem e se sustentam criam e mantêm esta diferenciação, ou seja, sabem muito bem qual é a essência do sucesso empresarial. Com isto promovem o aprendizado, a 
mudança constante e a melhoria contínua, além de aumentarem as barreiras à imitação, segundo os autores.

Os autores ainda citam que as empresas que promovem o crescimento sustentável possuem valores e princípios claros, ou seja, são transparentes e inegociáveis. Estes são adotados para converter a estratégia em decisões e ações consistentes, ou seja, norteiam o modo como a organização agirá. Entende-se organização como o conjunto das pessoas envolvidas em todo processo. Empresas que agem desta forma conseguem alinhar a equipe com o foco nos pontos fortes empresariais.

Por fim, os autores especificam o que chamaram de sistema de aprendizado dinâmico, ou seja, as empresas que crescem de forma sustentável criam métodos eficientes para perceber mudanças e adaptar-se a elas. Com isto criam um modo de trabalho que visa ter a certeza de que há uma melhora contínua e adaptação às constantes mudanças no ambiente organizacional e aspectos internos à empresa.

Desta forma, para esta pesquisa, evidenciam-se alguns prováveis impulsionadores de crescimento empresarial, conforme citado nos parágrafos anteriores. Quanto ao estudo de Zook e Allen (2012), para a DHoffmann Consultoria, pelo olhar e experiência do pesquisador, provavelmente se aplicariam os conceitos de comunicar claramente os valores empresariais e seus diferenciais e criar um sistema de trabalho que forneça à empresa as novidades de mercado ou ideias para aperfeiçoamento dos serviços e criação de novos.

\subsection{Serviços de consultoria e assessoria empresarial}

Dado que a atividade de consultoria e assessoria empresarial trata-se de um serviço prestado, é necessário conhecer o que é serviço e suas particularidades.

\footnotetext{
"Um serviço é um ato ou desempenho oferecido por uma parte à outra. Embora o processo possa estar vinculado a um produto físico, o desempenho é transitório, frequentemente de natureza intangível e não resulta normalmente em propriedade de quaisquer fatores de produção. Um serviço é uma atividade econômica que cria valor e proporciona benefícios a clientes em horários e locais específicos, efetuando uma mudança desejada em quem recebe o serviço, ou em seu nome" (LOVELOCK et al., 2006, pg. 21).
}

Cita-se abaixo algumas das grandes características dos serviços, segundo Lovelock et al. (2006):

- Clientes não obtêm a propriedade de serviços;

- Produtos que são serviços são efêmeros e não podem ser estocados; 
- Elementos intangíveis dominam a criação de valor;

- Clientes podem ser envolvidos no processo de produção;

- Outras pessoas geralmente fazem parte do produto;

- Há mais variabilidade entre insumos e produtos operacionais;

- Muitos serviços são difíceis de serem avaliados por clientes;

- O fator tempo adquire grande importância;

- Canais de distribuição assumem formas diferentes.

Ainda segundo Lovelock et al. (2006), existe uma forma de classificar os serviços e, consequentemente, o modo como interagir com eles. Os serviços podem ser de processamento de pessoas (os serviços são destinados aos corpos das pessoas, tais como serviços estéticos), processamento de posses (são serviços direcionados às posses físicas, tais como transportadoras de cargas), processamento de estímulo mental (são serviços dirigidos à mente das pessoas, tais como consultorias e educação) ou processamento de informações (são serviços direcionados a ativos intangíveis, tais como seguros). A consultoria e assessoria empresarial podem ser classificadas como um serviço de processamento de estímulo mental com a natureza de suas ações classificadas como intangíveis. Este tipo de serviço tem o poder de moldar atitudes e influenciar comportamentos. Normalmente este tipo de serviço requer tempo de dedicação de seus clientes. O conteúdo principal de todos os serviços dessa categoria é baseado em informações.

A consultoria, como uma prestação de serviço, é baseada no uso de um ou mais recursos humanos, a figura do consultor ou dos consultores. Uma pessoa que exerce influência sobre um indivíduo, grupo ou organização, sem poder direto de produzir mudanças pode ser chamado de consultor. Porém o seu alvo é influenciar a mudança de uma empresa (tratando-se de consultoria empresarial). Algumas características, que podem ser possíveis limitadores do crescimento das assessorias e consultorias empresariais, são delineadas, tais como: pessoalidade do atendimento (confusão entre a pessoa do consultor e a consultoria), confiança do cliente no executor (apenas em um consultor e não na consultoria) e o próprio consultor atuando como vendedor - confunde-se atividades de venda e entrega (BLOCK, 2001).

Estes podem ser limitadores do crescimento empresarial e o desafio se dá em criar uma estrutura replicável mantendo a pessoalidade e confiança não na figura do consultor (indivíduo), porém em sua própria estrutura (FRANCESCONI, 2016). 
Tratando-se da consultoria, como uma organização, uma das definições existentes refere-se a consultoria como uma aplicação de talentos, expertise, experiências e outros atributos relevantes, que resulta em melhorias nas condições de seus clientes (WEISS, 2009). Porém para adentrar no ramo de consultoria alguns pontos cruciais devem ser trabalhados, segundo Weiss (2009):

a) Estabelecer metas e expectativas;

b) Ter espaço físico e estrutura adequada;

c) Ter uma organização jurídica e financeira adequada;

d) Criar e ter um bom gerenciamento da marca;

e) Boa utilização das ferramentas de marketing para promoção da marca;

f) Uso de ferramentas tecnológicas para ganho de produtividade;

g) Ter processos bem definidos, principalmente relacionados a venda;

h) Evitar precificação por hora trabalhada, mas utilizar precificações fechadas por trabalho;

i) Planejar o crescimento empresarial.

Alguns dos pontos citados acima podem referir-se a possíveis impulsionadores do crescimento empresarial.

\subsection{Estratégia e posicionamento}

Existem diversos conceitos para estratégia aplicada às empresas, independente do porte. Para efeito desta pesquisa entende-se que a estratégia descreve como a organização pretende criar valor aos seus acionistas (ou proprietários), clientes e para a sociedade em geral (KAPLAN; NORTON, 2004). Valor, neste caso, é o montante (medido pela receita) que os compradores se dispõem a pagar por algo que uma empresa fornece (PORTER, 1985). A empresa se torna lucrativa se o valor exceder os custos envolvidos (PORTER, 1985). Portanto, criar valor econômico aos seus acionistas se relaciona com geração de receita e lucro. A forma como o valor é criado ou gerado é descrito pela estratégia.

Uma das formas para representar visualmente os componentes de uma estratégia organizacional é o mapa estratégico, que faz parte da estrutura do Balanced Scorecard. Tratase de um modelo que descreve as estratégias para criar valor através dos ativos tangíveis e intangíveis da empresa (KAPLAN; NORTON, 2004). O mapa estratégico é composto por quatro perspectivas que se relacionam entre si. São elas: (1) Perspectiva Financeira representa a estratégia financeira para gerar valor ao acionista, que é dirigida por duas 
alavancas, crescimento de receita e crescimento da produtividade; (2) Perspectiva dos Clientes - representa a proposta de valor aos clientes, que será delineada adiante; (3) Perspectiva dos Processos Internos - representa os meios que a empresa utilizará para gerar uma proposta de valor aos clientes com diferenciação e os ganhos de produtividade para alavancar resultados financeiros; (4) Perspectiva do Aprendizado e Crescimento - representa as competências essenciais e habilidades, tecnologias e a própria cultura organizacional necessária para apoiar a estratégia organizacional (KAPLAN; NORTON, 2000).

A proposta de valor aos clientes é o elemento central de qualquer estratégia de negócios e descreve um conjunto único de atributos de serviços ou produtos, o relacionamento com os clientes e a imagem corporativa que uma empresa revela (KAPLAN; NORTON, 2000). A proposta de valor aos clientes deixa claro como a empresa se diferenciará de seus concorrentes. Esta diferenciação pode ser gerada de três formas específicas, não excludentes, porém com uma prevalecendo perante as outras: (1) excelência operacional (normalmente competição em preço, qualidade, produto, ou grande eficiência em processos internos); (2) intimidade com o cliente (normalmente baseada em relacionamento profundo com clientes, alta qualidade de serviços e fornecimento de pacotes de soluções); e (3) liderança em produto (normalmente relacionado a funcionalidade e alta performance dos produtos ou serviços) (KAPLAN; NORTON, 2000). Estas também são chamadas de disciplinas de valor (TREACY; WIERSEMA, 1993).

A relação entre proposta de valor aos clientes, geração de valor econômico e estratégia é central para a diferenciação da oferta organizacional. Estas devem estar totalmente alinhadas e conectadas.

Ter uma definição das bases da proposta de valor empresarial (seja excelência operacional, intimidade com o cliente ou liderança em produto, ou um conjunto delas) provê a clareza necessária para que a oferta de um serviço ou um produto se diferencie na percepção de seus clientes e potenciais clientes. 


\section{METODOLOGIA}

A "pesquisa, de forma geral, define uma atividade que envolve descobertas diversas, de um modo sistemático" (WALLIMAN, 2015, pg. 5).

Segundo Hair Jr et al. (2005, pg. 31), “a pesquisa em administração é uma função de busca da verdade que reúne, analisa, interpreta e relata informações de modo que as decisões administrativas se tornem mais eficazes".

Esta pesquisa seguiu as orientações dos programas de mestrado profissionais que partem de um problema profissional de ordem prática, ou seja, da própria experiência do pesquisador. "A pesquisa profissional, ao contrário do que ocorre na pesquisa acadêmica, deve partir da prática para a teoria, numa relação dialógica” (ALMEIDA et al., 2019). Este método é baseado no modelo de aprendizagem de Kolb (Fig. 13 e 14), que é experiencial, ou seja, a aprendizagem se inicia com a prática (vivência ou experiência), há uma descrição do problema e sistematização, um momento de conhecimento buscando nas teorias relacionadas, e, após análise, o momento final é de contribuição através da nova aplicação prática (ou intervenção).

Figura 13 - Ciclo de aprendizagem experiencial de Kolb

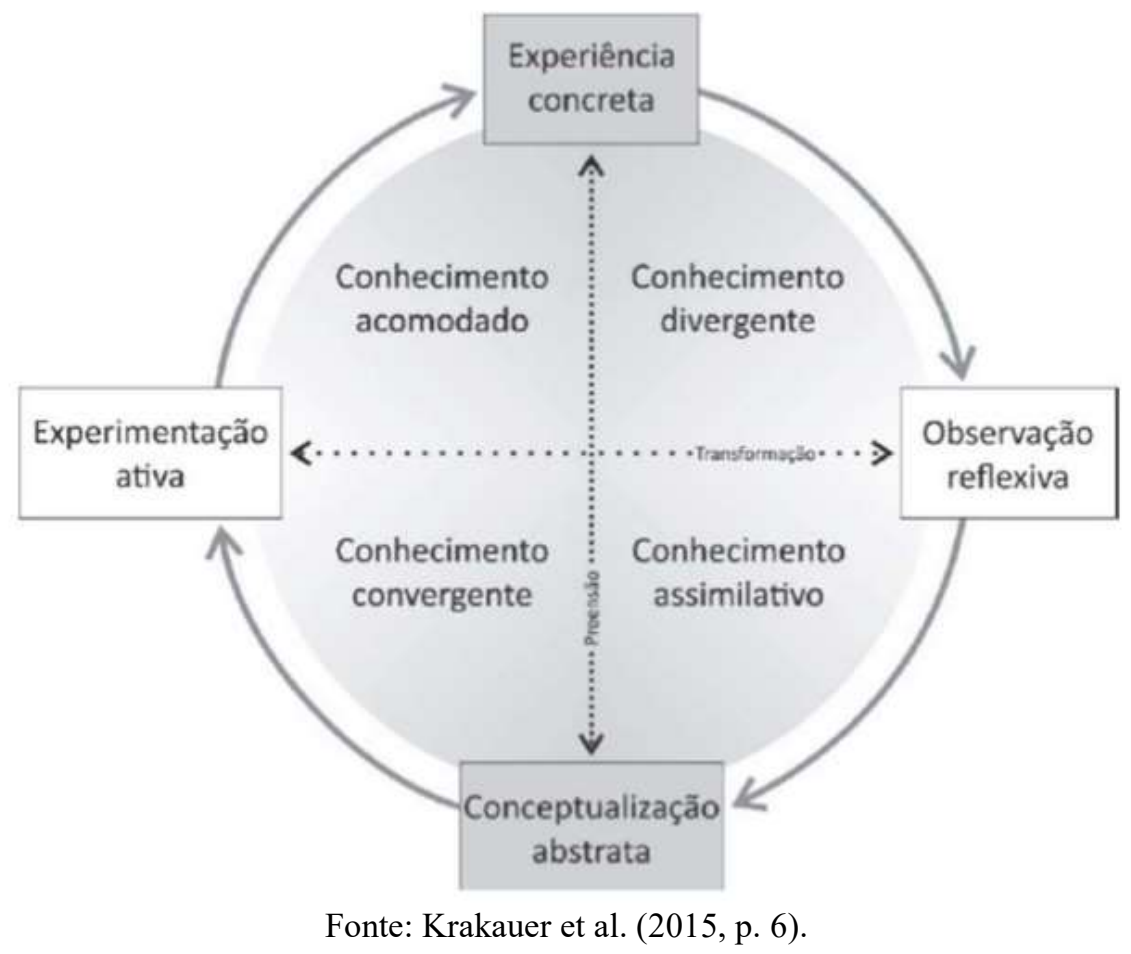


Figura 14 - Modelo Adaptado de Kolb (1984)

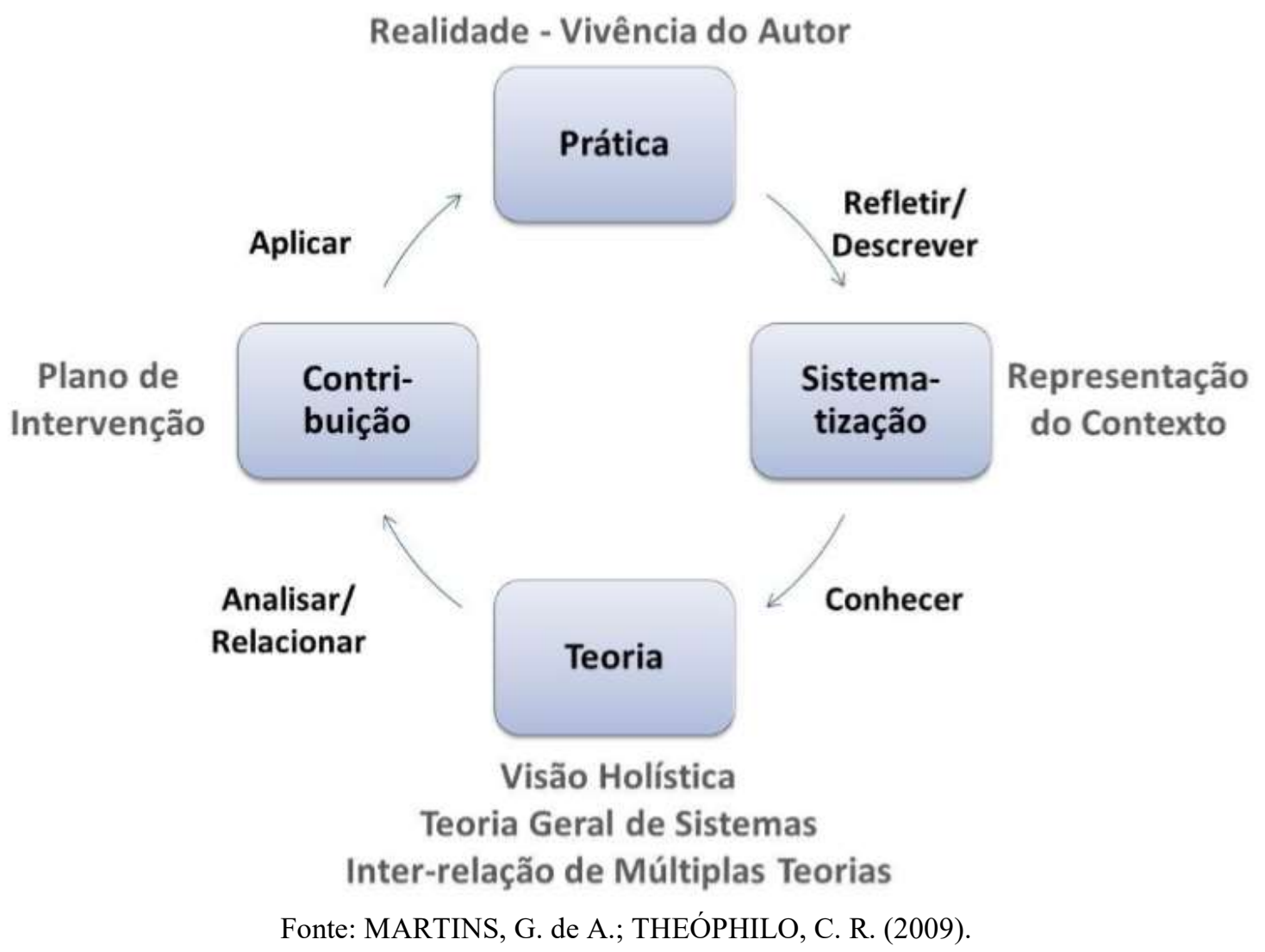

A pesquisa dentro de um programa de mestrado profissional segue uma sequência lógica de atividades se iniciando no relato da experiência do pesquisador e a identificação do problema de pesquisa. Posteriormente, o pesquisador realiza uma reflexão sobre o problema e busca teorias que possam contribuir com esta reflexão. Quando o pesquisador alcança uma maturidade teórica a respeito da sua pesquisa ele pode ir a campo para completá-la utilizando outros métodos e instrumentos para estudar a solução do problema (ALMEIDA et al., 2019). 
Figura 15 - Método de Pesquisa Profissional

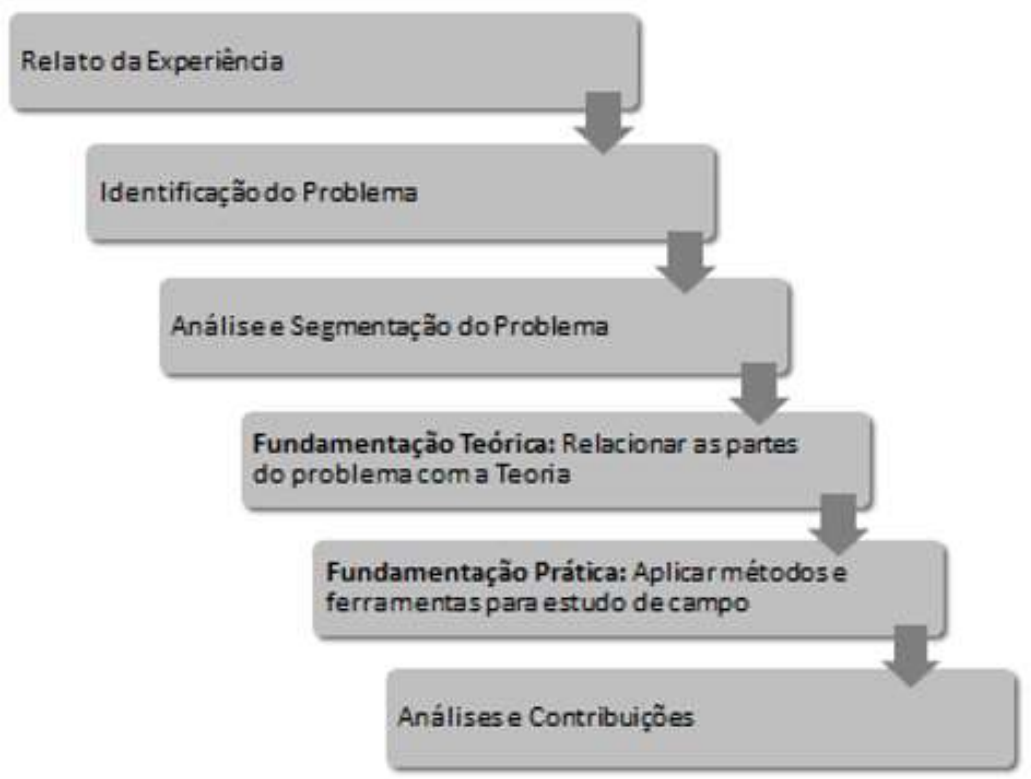

Fonte: ALMEIDA et al. (2019).

"A natureza do problema a ser estudado indica o tipo adequado de pesquisa a ser adotada" (WALLIMAN, 2015, pg. 11):

Figura 16 - Questão e Objetivo de Pesquisa
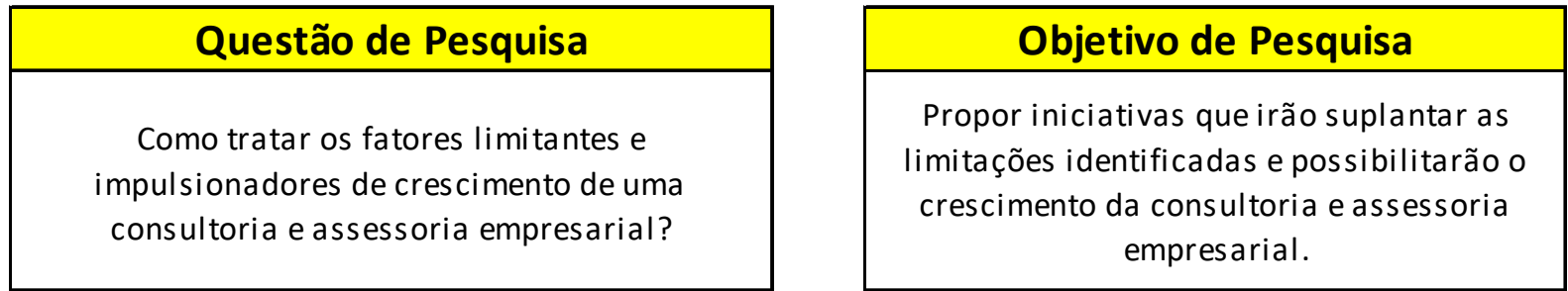

Fonte: próprio autor

Esta pesquisa é de natureza exploratória pois objetiva-se investigar "um fenômeno contemporâneo em profundidade e em seu contexto de vida real, especificamente quando os limites entre o fenômeno e o contexto não são claramente evidentes" (YIN, 2010). "Um projeto de pesquisa exploratório é útil quando as questões de pesquisa são vagas ou quando há pouca teoria disponível para orientar as previsões" (HAIR et al., 2005, pg. 83).

A abordagem desta pesquisa é qualitativa, que busca aprofundamento em um tema específico. Esta abordagem possui alguns aspectos essenciais, segundo FLICK (2009):

- Escolher adequadamente teorias e métodos;

- Reconhecer e analisar diferentes perspectivas;

- Reflexões do pesquisador sobre sua pesquisa como parte do processo de produção do conhecimento; 
- Variedade de abordagens e métodos.

Ainda segundo Flick (2009, pg. 25), “de modo diferente da pesquisa quantitativa, os métodos qualitativos consideram a comunicação do pesquisador em campo como parte explícita da produção de conhecimento".

A estratégia de pesquisa determina como será atingido o objetivo de pesquisa, ou como "diferentes maneiras de abordar e analisar dados empíricos no contexto das Ciências Sociais Aplicadas" (MARTINS, G. THEÓPHILO, C., 2009, pg. 53).

Para esta pesquisa, prevendo responder todos os objetivos secundários e fornecer subsídios para responder o principal, tratando-se de uma pesquisa profissional, foram determinadas as seguintes estratégias de pesquisa, conforme quadro na figura 17:

Figura 17 - Quadro Relacional entre objetivos e métodos de pesquisa

\begin{tabular}{|l|l|l|}
\hline \multicolumn{1}{|c|}{ Objetivos Secundários } & \multicolumn{1}{|c|}{$\begin{array}{c}\text { Tipo e } \\
\text { Abordagem de } \\
\text { Pesquisa }\end{array}$} & $\begin{array}{l}\text { Estratégia de } \\
\text { Pesquisa }\end{array}$ \\
\hline $\begin{array}{l}\text { 1- Identificar os fatores limitantes e } \\
\text { impulsionadores de crescimento na bibliografia } \\
\text { assim como soluções para o crescimento; }\end{array}$ & $\begin{array}{l}\text { Exploratória, } \\
\text { Qualitativa }\end{array}$ & $\begin{array}{l}\text { Pesquisa } \\
\text { Bibliográfica }\end{array}$ \\
\hline $\begin{array}{l}\text { 2- Pesquisar melhores práticas para } \\
\text { crescimento existentes em consultorias ou } \\
\text { assessorias empresariais. }\end{array}$ & $\begin{array}{l}\text { Exploratória, } \\
\text { Qualitativa }\end{array}$ & $\begin{array}{l}\text { Entrevistas } \\
\text { semiestruturadas }\end{array}$ \\
\hline
\end{tabular}

Fonte: Autoria própria (2018).

A primeira estratégia de pesquisa escolhida foi a de pesquisa bibliográfica, que procura "explicar e discutir um assunto, tema ou problema com base em referências publicadas" (MARTINS, G. THEÓPHILO, C., 2009, pg. 54). "Na pesquisa qualitativa, o pesquisador utiliza os insights e as informações provenientes da literatura enquanto conhecimento sobre o contexto, utilizando-se dele para verificar afirmações e observações a respeito do seu tema de pesquisa naqueles contextos" (FLICK, 2009, pg. 62). Para efeito desta pesquisa, a pesquisa bibliográfica teve como objetivo determinar achados relacionados ao problema de pesquisa, mais especificamente aos limitadores ou impulsionadores de crescimento para consultorias e assessorias empresariais. Desta forma cumprir o objetivo secundário de identificar os fatores limitantes e impulsionadores de crescimento. 
A segunda estratégia escolhida foi a de realização de entrevistas semiestruturadas a fim de "responder a questões acerca da distribuição de uma variável ou das relações entre características de pessoas ou grupos, da maneira como ocorrem em situações naturais" (MARTINS, G. THEÓPHILO, C., 2009, pg. 60). É uma estratégia de coleta de dados primários a partir de indivíduos (HAIR et al., 2005). Foi utilizada para cumprir o objetivo secundário de identificar as melhores práticas empresariais para crescimento organizacional.

Quanto ao objetivo secundário número 2 o instrumento de pesquisa escolhido, como uma pesquisa de campo, foi o de realizar entrevistas semiestruturadas. "Entrevista é uma interação verbal, uma conversa, um diálogo, uma troca de significados, um recurso para se produzir conhecimento sobre algo" (VERGARA, 2009, p. 3).

\footnotetext{
Esta técnica de pesquisa para coleta de informações, dados e evidências cujo objetivo básico é entender e compreender o significado que entrevistados atribuem a questões e situações, em contextos que não foram estruturados anteriormente, com base nas suposições e conjecturas do pesquisador. A entrevista semiestruturada é conduzida com uso de um roteiro, mas com liberdade de serem acrescentadas novas questões pelo entrevistador (MARTINS et al., 2009).
}

A terceira estratégia escolhida foi a de pesquisa-ação, para cumprir o terceiro objetivo secundário, que é elaborar uma sistematização das iniciativas que irão suplantar as limitações identificadas e possibilitarão o crescimento da consultoria e assessoria empresarial para validação posterior. A pesquisa-ação "é um tipo de pesquisa social com base empírica que é concebida e realizada em estreita associação com uma ação ou com a realização de um problema coletivo e no qual os pesquisadores e os participantes representativos da situação ou do problema estão envolvidos de modo cooperativo ou participativo" (THIOLLENT, 2005, p. 16). No âmbito da pesquisa dentro dos programas de mestrado profissionais, o pesquisador deverá fazer uma proposta de intervenção e verificar no futuro o seu resultado, onde ele é participante da intervenção. Este caso é conhecido como Pesquisa-ação participante (ALMEIDA et al., 2016). A pesquisa-ação tem sido definida como um tipo de investigação participante que tem como característica peculiar o propósito de ação planejada sobre os problemas detectados (MARTINS et al., 2009). Nesta pesquisa, o pesquisador é participante ativo do problema pois é o proprietário da organização a qual deu origem a pesquisa. Como é parte deste trabalho a constituição de uma sistemática de iniciativas (ou plano de intervenção), se fez necessário uma estratégia de pesquisa como a pesquisa-ação. 
A pesquisa-ação, de forma didática, é apresentada (Fig. 18) com fases estanques e interdependentes, mas o que ocorreu nesta pesquisa foi que as ações começaram a serem implantadas ainda durante a pesquisa, agilizando o processo de aprendizagem.

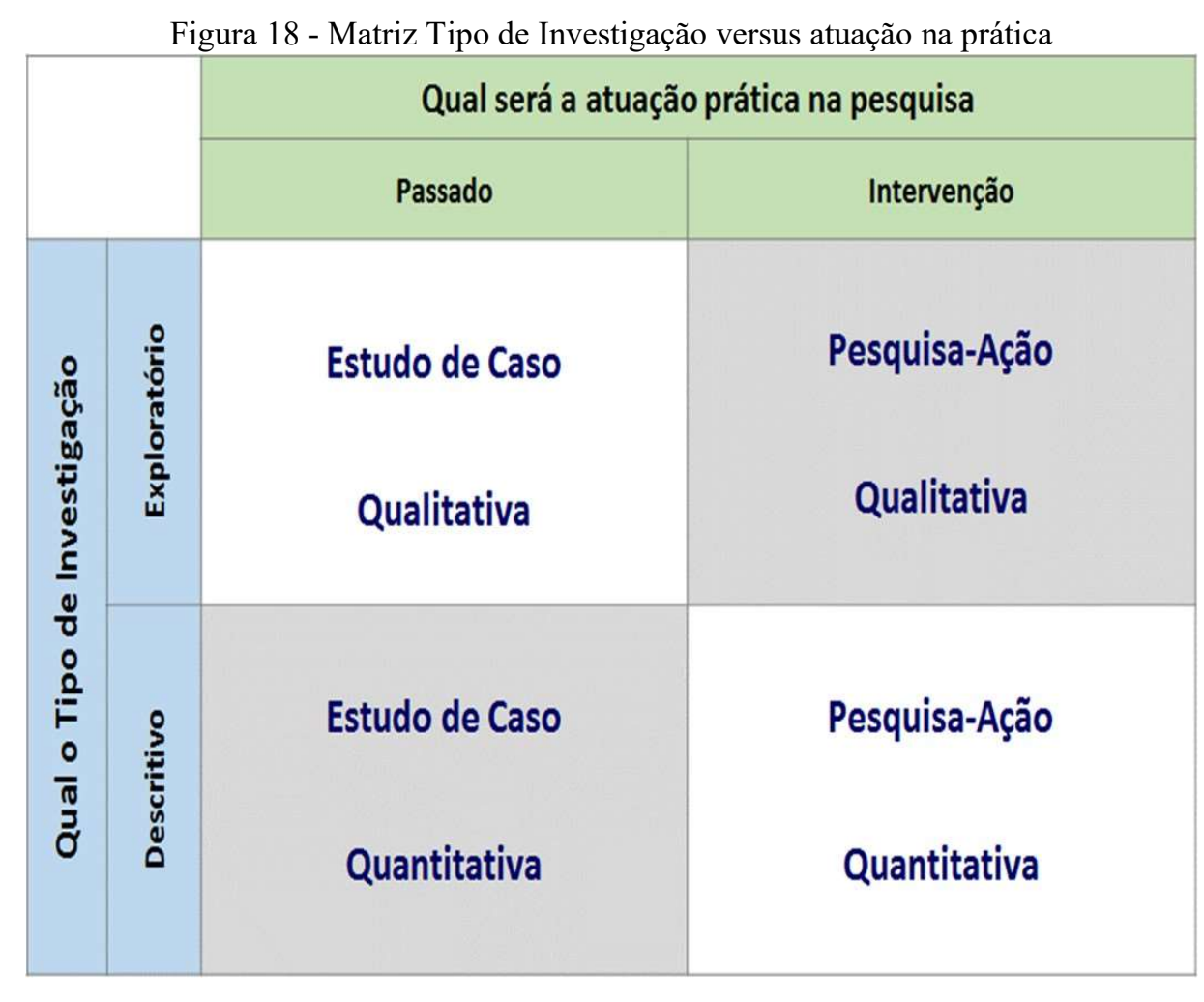

Fonte: ALMEIDA et al., 2019.

Segundo Kurt Lewin, criador da pesquisa-ação (Fig. 19), a "pesquisa-ação se constitui um ciclo de análise, fato achado, concepção, planejamento, execução e mais fato-achado ou avaliação" (MARTINS, G. THEÓPHILO, C., 2009, pg. 72). 
Figura 19 - Ciclo da Pesquisa-Ação segundo Kurt Lewin

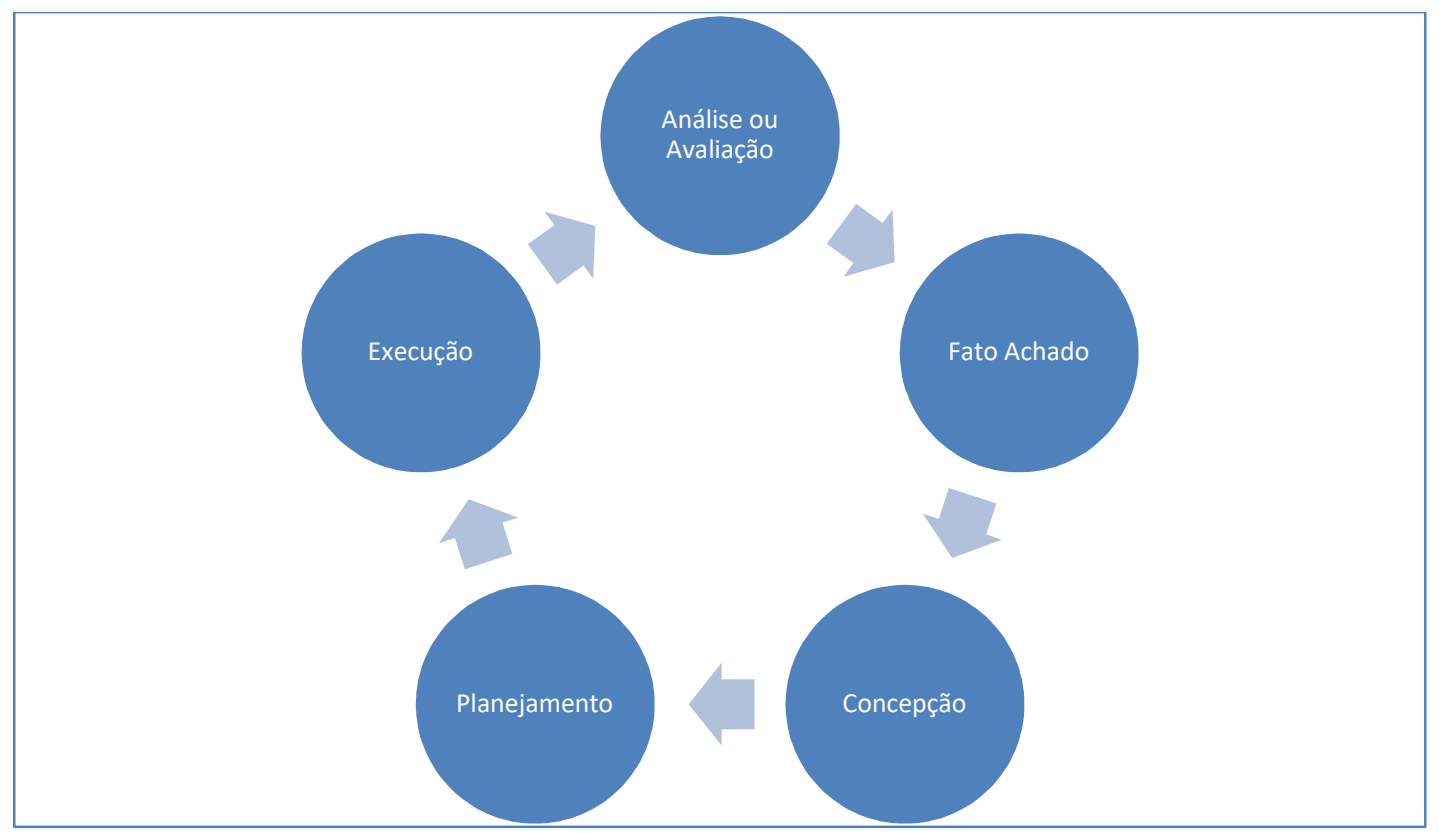

Fonte: Adaptado pelo pesquisador (2018).

A pesquisa-ação tem, em sua estrutura, cinco grandes etapas, segundo Martins e Theóphilo (2009):

- Diagnóstico ou busca dos problemas na organização estudada ou objeto de estudo;

- Planejamento do estudo considerando as ações para resolver os problemas identificados;

- Execução das ações planejadas;

- Avaliação da consequência de cada ação;

- Aprendizagem específica e identificação dos ensinamentos da experiência.

A técnica de análise escolhida para esta pesquisa foi a de triangulação. Várias fontes de evidências foram utilizadas, sendo que a significância dos achados terá mais qualidade ainda se as técnicas forem distintas (MARTINS, G. THEÓPHILO, C., 2009), aliando os achados na teoria (pesquisa bibliográfica), os achados na pesquisa de campo (oriundos das entrevistas semiestruturadas) e da aplicação do plano de intervenção traçado. A triangulação "é utilizada para designar a combinação de diversos métodos, grupos de estudo, ambientes locais e temporais e perspectivas teóricas distintas para tratar de um fenômeno" (FLICK, 2009, pg. 361). Nesta dissertação a triangulação ocorreu na utilização das fontes: problemática prática evidenciada, referências bibliográficas, achados nas entrevistas e observações quanto as intervenções realizadas. 


\subsection{Definição dos entrevistados}

Nesta seção será explicitado como foi definido o grupo participante das entrevistas semiestruturadas, ou os entrevistados.

Dentro de uma população determinada, entendendo-se população como o conjunto de indivíduos ou objetos que apresentam em comum determinadas características definidas para o estudo, escolhe-se uma amostra, que é um subconjunto da população (MARTINS, G. THEÓPHILO, C., 2009).

A amostra escolhida, aqui denominada como entrevistados, para esta pesquisa é do tipo não probabilística, ou seja, baseada na seleção por meios não aleatórios (WALLIMAN, 2015). É uma amostragem intencional pois o pesquisador se dirige, intencionalmente, a uma amostra que atende determinados critérios pré-estabelecidos (MARTINS, G. THEÓPHILO, C., 2009). É também uma amostragem por conveniência pois envolve a seleção de elementos de amostra que estejam mais disponíveis para tomar parte do estudo e que podem oferecer as informações necessárias (HAIR et al., 2005).

Os entrevistados desta pesquisa foram selecionados para participar das entrevistas semiestruturadas a fim de coletar dados para atender ao objetivo secundário: pesquisar melhores práticas para crescimento existentes em consultorias ou assessorias empresariais. Portanto, alguns critérios foram pré-estabelecidos:

- Ser proprietário de uma empresa prestadora de serviços e que trabalha com serviços de consultoria ou assessoria empresarial: o fato de ser proprietário remete à autonomia de construir e implementar ações para crescimento e o fato de ser uma empresa de consultoria ou assessoria empresarial (como prestadora de serviços) se assemelha ao tipo de serviço da empresa que originou o problema desta pesquisa;

- Não apenas ser proprietário mas também executar atividades nestas empresas: denota experiência prática nas atividades empresariais;

- Ter passado por uma experiência de crescimento em sua empresa: revela vivência no objeto de estudo desta pesquisa e capacidade de contribuir com o tema.

O conjunto dos entrevistados originalmente definido seria composto de cinco entrevistas, porém seis foram realizadas. 
O pesquisador, sendo consultor e empresário, utilizou-se de sua rede de contatos para elencar a amostra, dentro dos critérios estabelecidos. Abaixo (Fig. 20) quadro contendo os entrevistados, suas características, data e tempo de execução das entrevistas.

Figura 20 - Quadro Controle dos Entrevistados

\begin{tabular}{|l|l|l|l|l|l|}
\hline $\begin{array}{c}\text { Identificação do } \\
\text { Entrevistado }\end{array}$ & $\begin{array}{c}\text { Ramo de Atividade da } \\
\text { Empresa }\end{array}$ & $\begin{array}{c}\text { Data da } \\
\text { Entrevista }\end{array}$ & $\begin{array}{c}\text { Duração da } \\
\text { Entrevista } \\
\text { (minutos) }\end{array}$ & $\begin{array}{c}\text { Canal de } \\
\text { Comunicação }\end{array}$ & Observações \\
\hline Entrevistado 1 & $\begin{array}{l}\text { Consultoria Estratégica em } \\
\text { Marketing }\end{array}$ & $02 / 03 / 2018$ & 75 & Remoto (Skype) & $\begin{array}{l}\text { Realizado pré-teste com sucesso e dados para } \\
\text { utilização posterior dentro do padrão }\end{array}$ \\
\hline Entrevistado 2 & Assessoria Contábil & $27 / 03 / 2018$ & 50 & Presencial & Realizada entrevista dentro do padrão \\
\hline Entrevistado 3 & Corretora de Investimentos & $02 / 04 / 2018$ & 55 & Presencial & Realizada entrevista dentro do padrão \\
\hline Entrevistado 4 & Serviços Advocatícios & $02 / 04 / 2018$ & 90 & Presencial & Realizada entrevista dentro do padrão \\
\hline Entrevistado 5 & Auditoria e Assessoria Contábil & $20 / 04 / 2018$ & 55 & Presencial & Realizada entrevista dentro do padrão \\
\hline Entrevistado 6 & Recuperação de Recebíveis e & $26 / 04 / 2018$ & 60 & Presencial & Realizada entrevista dentro do padrão \\
\hline
\end{tabular}

Fonte: Autoria própria (2018).

Observa-se que o conjunto de entrevistados contém proprietários de empresas do setor de serviços, sendo consultorias e assessorias empresariais, e todas passaram por um processo de crescimento.

\subsection{Método de Coleta e Instrumento de Pesquisa}

Como já citado, o método de coleta escolhido foi a realização de entrevistas semiestruturadas a fim de coletar dados para atender ao objetivo secundário: pesquisar melhores práticas para crescimento existentes em consultorias ou assessorias empresariais.

Para o preparo deste método de coleta foram observadas as seguintes considerações elencadas por Martins e Theóphilo, 2009:

- Planejar a entrevista, delineando o objetivo a ser alcançado;

- Quando possível, obter algum conhecimento prévio sobre o entrevistado;

- Atentar para os itens que o entrevistado deseja esclarecer, sem manifestar opiniões;

- Obter e manter a confiança do entrevistado;

- Ouvir mais do que falar;

- Evitar divagações;

- Registrar as informações, dados e evidências durante a entrevista;

- Com a concordância do entrevistado, usar gravador; 
- Se necessário, formular questões secundárias.

A entrevista semiestruturada parte de um roteiro explícito de questões predefinido de acordo com a problemática evidenciada na pesquisa e itens já consultados na teoria. Porém, por sua natureza de aplicação, não se limita a estas questões. Tudo que for perguntado deve ter uma relação direta com o objetivo da pesquisa e deverá ser utilizado na análise da pesquisa (ALMEIDA et al., 2019). Na Figura 21 foram elencadas oito questões de pesquisa relacionadas diretamente ao objetivo e segmentação do problema apresentado para serem incorporadas ao roteiro de pesquisa.

Figura 21 - Relação da Segmentação do Problema com Objetivo e Questões de Pesquisa

\begin{tabular}{|c|c|c|}
\hline $\begin{array}{l}\text { Segmentação } \\
\text { do Problema }\end{array}$ & $\begin{array}{c}\text { Objetivo } \\
\text { Secundário }\end{array}$ & Questões de Pesquisa \\
\hline Recursos Limitados & \multirow{3}{*}{$\begin{array}{l}\text { Pesquisar melhores } \\
\text { práticas para } \\
\text { crescimento } \\
\text { existentes em } \\
\text { consultorias ou } \\
\text { assessorias } \\
\text { empresariais }\end{array}$} & $\begin{array}{l}\text { 1- Um dos problemas enfrentados pela DHoffmann é a falta de tempo do consultor, contando apenas } \\
\text { com um consul tor executor. Você já passou por isso?; } \\
\text { 2- O perfil do empreendedor pode ser um empecilho ou um impulsionador do crescimento } \\
\text { empresarial?; } \\
\text { 3- Os membros da família, como recursos a utilizar na organização, foram utilizados como } \\
\text { ferramentas de crescimento?; } \\
\text { 4- Quais recursos essenciais utilizados para impul sionar o crescimento?; }\end{array}$ \\
\hline $\begin{array}{l}\text { Baixo Nível de } \\
\text { Padronização }\end{array}$ & & $\begin{array}{l}\text { 5- Um dos problemas enfrentados pela DHoffmann é a falta de padronização de processos } \\
\text { operacionais. Você passou por isso?; } \\
\text { 6- Ter estrutura física própria foi essencial como propulsor do crescimento?; } \\
\text { 7- A padronização de processos foi essencial ao crescimento?; }\end{array}$ \\
\hline $\begin{array}{l}\text { Posicionamento } \\
\text { sem Clareza }\end{array}$ & & $\begin{array}{l}\text { 8- Um dos problemas enfrentados pela DHoffmann é a limitação de inovação no portfolio. Você passou } \\
\text { por isso?. }\end{array}$ \\
\hline
\end{tabular}

Fonte: Autoria própria (2018).

$\mathrm{O}$ roteiro (instrumento de pesquisa) desenhado e aplicado continha um objetivo explícito que era: 'espera-se encontrar iniciativas existentes em negócios correlatos que mostrarão tendências ou possíveis soluções para aumento de escalabilidade. Além disto, será necessário entender a história de sucesso e o que possibilitou a expansão das atividades'. 
Este roteiro possuía um bloco inicial chamado "Abertura" contendo instruções explícitas ao entrevistador para serem executadas a cada entrevista. São elas:

a) Contextualize o entrevistado sobre a história da DHoffmann e seu momento atual;

b) Apresente o objetivo da entrevista em questão dentro do contexto da pesquisa acadêmica;

c) Fale sobre a importância do entrevistado neste processo e agradeça sua participação;

d) Explique a importância da transparência das respostas, devendo refletir sua percepção real sobre o fato;

e) Fale que a entrevista será gravada apenas para fins acadêmicos e se o entrevistado autoriza a realização da gravação (Os dados dessa entrevista são confidenciais e serão utilizados somente para fins acadêmicos. Os resultados finais serão publicados de forma agregada após a defesa da tese e os nomes dos respondentes serão divulgados somente com autorização);

f) Coletar nome, empresa, tempo de empresa e tempo na função.

O bloco seguinte do roteiro, denominado "Sobre consultoria e assessoria empresarial limitações ao crescimento", se referia a questões direcionadas ao levantamento dos fatores de limitação ao crescimento empresarial e continha algumas das questões já citadas anteriormente e instruções ao entrevistador. O conteúdo completo segue a seguir:

a) Questão 1: "Você lida com processo de consultoria e assessoria empresarial. Em sua opinião, quais são as características mais marcantes deste tipo de serviço?"

ENTREVISTADOR: a pergunta pode ser adaptada dependendo do público. Explorar pontos fortes e fracos e se estes se configuram limitantes do crescimento.

b) Questão 2: "Dentro da sua história neste tipo de serviço, quais foram as características que limitaram o crescimento da organização em seu início? Quais os maiores desafios?"

c) Questão 3: "Um dos problemas enfrentados pela DHoffmann é a falta de tempo do consultor, contando apenas com um consultor executor. Você já passou por isso? Se sim, quais impactos na organização? O que aprendeu com isto e o que recomendaria para lidar com isto?"

d) Questão 4: "Um dos problemas enfrentados pela DHoffmann é a limitação de inovação no portfólio. Você passou por isso? Como superou?"

e) Questão 5: "Um dos problemas enfrentados pela DHoffmann é a falta de padronização de processos operacionais. Você passou por isso? Como superou?" 
f) Questão 6: “O perfil do empreendedor pode ser um empecilho ou um impulsionador do crescimento empresarial?"

g) Questão 7: "Mais algum desafio que se lembre?"

O terceiro bloco, "Sobre os impulsionadores de crescimento da empresa", explorou questões acerca dos fatores que impulsionaram o crescimento das empresas dos entrevistados e instruções ao entrevistador. Abaixo segue a relação das questões deste bloco do roteiro:

a) Explique sobre a estrutura da DHoffmann e o seu desejo de crescer

b) Questão 6: "Em sua opinião, quais são os maiores desafios para a empresa crescer em seu estágio inicial (quando encontra os limitadores de crescimento)?”

ENTREVISTADOR: gerar outras perguntas na tentativa de segmentar os desafios e caracterizá-los

c) Questão 7: “O que impulsionou o crescimento da sua empresa? Quais as ferramentas e recursos utilizados?"

ENTREVISTADOR: gerar outras perguntas na tentativa de agrupar os fatores limitantes

d) Questão 8: “Os membros da família, como recursos a utilizar na organização, foram utilizados como ferramentas de crescimento? Tiveram algum papel importante em algum momento?"

e) Questão 9: "Ter estrutura física própria foi essencial como propulsor do crescimento?"

f) Questão 10: "Quais recursos essenciais utilizados para impulsionar o crescimento?"

g) Questão 11: “A padronização de processos foi essencial ao crescimento?”

O último bloco relacionava a instrução final ao entrevistador remetendo ao fechamento da entrevista e agradecimento endereçado ao entrevistado. Bloco denominado "Agradecimento e saudação final”, com os seguintes dizeres: "Muito obrigado pela sua colaboração. Ao final da pesquisa, será enviada uma cópia digital da dissertação. Caso você tenha alguma dúvida, sugestão, crítica ou comentário após essa entrevista, fique à vontade em me procurar. Enviarei um e-mail com meus contatos".

\subsection{Aplicação das entrevistas semiestruturadas}

Neste tópico será abordado como ocorreu a aplicação do instrumento de pesquisa de campo, os roteiros das entrevistas semiestruturadas. 
As entrevistas foram realizadas entre os dias $02 / 03 / 2018$ a $26 / 04 / 2018$, seguindo o roteiro apresentado anteriormente.

A seguir é apresentado o quadro-resumo de cada entrevista contendo entrevistado (Fig. 22), ramo de atividade da empresa, data da entrevista, duração da entrevista, canal de comunicação da entrevista e observações gerais.

Figura 22 - Quadro de entrevistados

\begin{tabular}{|l|l|r|r|r|l|}
\hline $\begin{array}{c}\text { Identificação do } \\
\text { Entrevistado }\end{array}$ & $\begin{array}{c}\text { Ramo de Atividade da } \\
\text { Empresa }\end{array}$ & $\begin{array}{c}\text { Data da } \\
\text { Entrevista }\end{array}$ & $\begin{array}{r}\text { Duração da } \\
\text { Entrevista } \\
\text { (minutos) }\end{array}$ & $\begin{array}{c}\text { Canal de } \\
\text { Comunicação }\end{array}$ & Observações \\
\hline Entrevistado 1 & $\begin{array}{l}\text { Consultoria Estratégica em } \\
\text { Marketing }\end{array}$ & $02 / 03 / 2018$ & 75 & Remoto (Skype) & $\begin{array}{l}\text { Realizado pré-teste com sucesso e dados para } \\
\text { utilização posterior dentro do padrão }\end{array}$ \\
\hline Entrevistado 2 & Assessoria Contábil & $27 / 03 / 2018$ & 50 & Presencial & Realizada entrevista dentro do padrão \\
\hline Entrevistado 3 & Corretora de Investimentos & $02 / 04 / 2018$ & 55 & Presencial & Realizada entrevista dentro do padrão \\
\hline Entrevistado 4 & Serviços Advocatícios & $02 / 04 / 2018$ & 90 & Presencial & Realizada entrevista dentro do padrão \\
\hline Entrevistado 5 & Auditoria e Assessoria Contábil & $20 / 04 / 2018$ & 55 & Presencial & Realizada entrevista dentro do padrão \\
\hline Entrevistado 6 & $\begin{array}{l}\text { Recuperação de Recebíveis e } \\
\text { Serviços Advocatícios }\end{array}$ & $26 / 04 / 2018$ & 60 & Presencial & Realizada entrevista dentro do padrão \\
\hline
\end{tabular}

Fonte: Autoria própria (2018).

Foi realizado pré-teste com o entrevistado denominado entrevistado 1. A escolha por este se deu por se tratar de um proprietário de uma empresa de consultoria (mais de 10 anos de empresa) que obteve crescimento e também por ele ser mestre, ou seja, conhecedor de pesquisas científicas e poder colaborar com a própria validação do instrumento de pesquisa. A entrevista foi realizada remotamente pelo software Skype no dia 02/03/2018 e durou cerca de 75 minutos. Todas as instruções foram seguidas e todas as questões realizadas e devidamente respondidas. Nesta entrevista constatou-se um limitador ao crescimento empresarial não constatado anteriormente, que seria o comportamento dos sócios ou falta de alinhamento entre os sócios, ou seja, um fator comportamental dos empreendedores. Com isto, a questão número seis ("O perfil do empreendedor pode ser um empecilho ou um impulsionador do crescimento empresarial?") foi adicionada ao roteiro e aplicada aos demais entrevistados. Quando indagado sobre o roteiro como instrumento de pesquisa (para efeito de pré-teste), o entrevistado 1 não colocou nenhuma objeção e nem sugestões. Desta forma o roteiro foi validado e utilizado, mesmo constando uma pergunta adicional que foi replicada as demais entrevistas. Os dados do entrevistado 1 foram armazenados e as demais entrevistas realizadas. 
Para as demais entrevistas (todas realizadas presencialmente) foram seguidos os seguintes passos:

- O pesquisador realizou uma abertura agradecendo a participação do entrevistado e disponibilização de seu tempo;

- Explicou sobre o processo de pesquisa e contexto da empresa DHoffmann;

- Solicitou transparência nas respostas, explicou sobre o não uso dos nomes no documento de pesquisa e solicitou autorização para gravação da entrevista e realização de anotações durante o processo. Para gravação foi utilizado o gravador do Windows e o gravador do telefone celular. A pesquisa realizada por Skype foi gravada em um programa específico para gravação de conferências pelo Skype;

- Realizou o preenchimento dos dados cadastrais do entrevistado em documento específico do Microsoft Word (foi aberto um para cada entrevistado);

- Realizou os questionamentos do roteiro e realizou anotações no mesmo documento do Microsoft Word;

- Ao final, agradeceu novamente ao entrevistado e comprometeu-se a remeter o documento final a ele;

- O arquivo eletrônico da gravação da entrevista foi salvo no computador pessoal do pesquisador, assim como o arquivo de anotações, um para cada entrevistado com identificação própria.

Como tratado anteriormente, o conjunto original de entrevistados era de cinco e, ao longo do processo de coleta de dados, estendeu-se a seis. Incluiu-se mais um entrevistado da rede de contatos do pesquisador, como uma escolha por conveniência, por ter perfil requerido pela pesquisa. O pesquisador decidiu inclui-lo para coletar dados adicionais. Ao longo da realização das entrevistas observou-se que houve saturação ou exaustão das respostas, pela repetição das respostas principais, acerca dos limitadores e impulsionadores do crescimento empresarial. Desta forma, pelo método de exaustão (baseado no método de "saturação teórica"), constatou-se o esgotamento do conjunto selecionado não necessitando de adicionar mais entrevistados, pois não houveram achados adicionais na última entrevista, mas sim repetição dos achados anteriores. Uma decisão muito importante neste tipo de coleta de dados é decidir sobre quando interromper a integração de entrevistado adicional. Existe um critério denominado "saturação teórica”, de Glaser e Strauss (1965), “o critério para a avaliação sobre quando interromper a amostragem de diferentes grupos pertinentes a uma categoria é a 
saturação teórica da categoria. A saturação significa que não estão sendo encontrados dados adicionais por meio dos quais o sociólogo possa desenvolver as propriedades da categoria" (STRAUSS et a1, 1967). A amostragem e a integração de outros materiais são concluídas quando a "saturação teórica" de uma categoria ou grupo de casos tenha sido atingida, ou seja, quando não surgir mais nada novo (FLICK, 2009). 


\section{ANÁLISE DOS DADOS E RESULTADOS}

Neste capítulo serão apresentados os resultados e análise dos dados primários coletados através das seis entrevistas semiestruturadas aplicadas. O intuito foi de satisfazer o objetivo secundário "pesquisar melhores práticas para crescimento existentes em consultorias ou assessorias empresariais".

O conjunto dos entrevistados foi definido e explicitado no capítulo anterior assim como a forma de aplicação do instrumento de pesquisa (roteiro de entrevista).

A análise das entrevistas realizadas visou listar os exemplos práticos utilizados pelos entrevistados para combater os limitadores do crescimento, ou seja, o que foi executado para suas empresas crescerem. Da mesma forma, observou-se quais eram os limitadores de crescimento apresentado por eles e quais os impulsionadores utilizados. O pesquisador preferiu explorar também os dados coletados em entrevista para checagem se haveria acréscimo ou não de limitadores citados na bibliografia.

Para executar a coleta e organização do material a ser analisado, as entrevistas foram gravadas com autorização dos entrevistados. Durante o processo de entrevista o pesquisador realizou notas em arquivos eletrônicos individualizados frente a tópicos importantes em cada uma das questões apresentadas, seguindo o roteiro de entrevista. $\mathrm{O}$ pesquisador procurou enfatizar o levantamento dos limitantes e impulsionadores do crescimento empresarial assim como exemplos concretos do que cada um dos entrevistados realizou em suas respectivas empresas.

Após a organização do material, o pesquisador, utilizando-se de suas anotações e das gravações, pôde identificar os limitadores e impulsionadores citados pelos entrevistados. Esta lista surgiu da própria exploração das mensagens dos entrevistados e não de categorias criadas previamente através de referencial teórico. Isto para utilizar o máximo potencial do processo exploratório das entrevistas.

Por fim, também gerou uma lista de exemplos práticos vivenciados pelos entrevistados vinculados aos limitadores e impulsionadores de crescimento.

Nos próximos tópicos serão detalhados os processos citados anteriormente.

\subsection{Limitadores do crescimento empresarial}

Neste tópico será abordado como extraiu-se das entrevistas os limitadores de crescimento citados pelos entrevistados, gerando uma lista de nove limitadores identificados. 
Retomando os objetivos secundários traçados tem-se:

- Identificar os fatores limitantes e impulsionadores de crescimento na bibliografia, assim como soluções para o crescimento;

- Pesquisar melhores práticas para crescimento existentes em consultorias ou assessorias empresariais.

Frente aos objetivos acima, ficou evidente que a busca teórica pelos fatores limitantes e impulsionadores de crescimento precisaria ser validada pela prática, ou seja, quais foram realmente os fatores limitantes para as empresas dos entrevistados crescerem e quais foram os impulsionadores de crescimento (chamado no objetivo como melhores práticas para o crescimento). Além disto, houve uma preocupação em evidenciar exemplos práticos vivenciados a fim de ilustrar as boas práticas utilizadas.

Como já explicitado, foram realizadas notas para cada entrevista e houve gravação individual de cada uma. O pesquisador, com estas em mãos, realizou um agrupamento dos limitadores de crescimento evidenciado nas entrevistas. Estas foram organizadas em nove grandes fatores limitadores do crescimento empresarial, segundo os entrevistados.

Como já abordado em seu roteiro, o início da entrevista se dá com uma abertura e posteriormente se inicia um bloco de questões para identificar os limitadores de crescimento segundo os entrevistados. Porém, a primeira questão é "você lida com processo de consultoria e assessoria empresarial. Em sua opinião, quais são as características mais marcantes deste tipo de serviço?". As respostas levaram para as seguintes características:

- É um serviço profissional: segundo o entrevistado 1 "este serviço não é um favor, é um serviço profissional assim como contador, advogado”. Pois tratava-se de uma consultoria empresarial clássica e o nível de relacionamento com seus clientes pode levar a certa confusão entre pessoal e profissional;

- É um serviço heterogêneo: principalmente quando se trabalha com projetos com alto grau de customização. Segundo o entrevistado 1, este serviço "depende de variáveis incontroláveis também e dos clientes utilizarem seus apontamentos”, ou seja, o êxito do serviço não depende totalmente do consultor ou de quem o está executando;

- É um serviço pautado na confiança: a base deste tipo de prestação de serviço é a confiança, que vem do relacionamento entre o fornecedor e o cliente em todas as suas dimensões. Para se ter sucesso neste tipo de negócio, "a chave é construir relação de 
confiança, entregar o prometido", segundo o entrevistado 2. "O consultor deve saber ouvir e depois fazer o diagnóstico. Ter postura e conhecimento, para ganhar confiança. Aqui é relacionamento puro, pois tratamos com dinheiro. O pilar central é a confiança”, segundo o entrevistado 3. "A construção da confiança junto ao cliente vem da transparência com o cliente”, segundo o entrevistado 6;

- É um serviço em que as pessoas são fundamentais: "como vendemos conhecimento, o pilar central são as pessoas, administração de capital intelectual”, segundo entrevistado 5.

Analisando as respostas, pelas citações dos entrevistados, identifica-se que o processo de consultoria e assessoria trata-se de uma prestação de serviço e, desta forma, possui as características comuns a serviços com características acentuadas de um serviço especializado, dependendo de pessoas habilitadas para a entrega do serviço, para, assim, fortalecer o pilar central citado: a confiança (e esta fortalece o relacionamento entre as partes). Portanto, alguns elementos limitadores de crescimento já foram elencados nesta primeira questão e posteriormente detalhados, como nos próximos parágrafos.

A seguir serão apresentados os nove limitadores de crescimento identificados nas entrevistas e os seus significados.

1) O perfil e objetivos entre sócios não estão alinhados com as necessidades organizacionais: diz respeito à interferência, positiva ou não, no negócio causada pelas diferenças entre valores pessoais, personalidade, ambição e objetivos relacionados ao negócio pelos sócios da empresa. Não deixa de ser também um limitador relacionado a pessoas, que é uma grande característica do negócio, como citado anteriormente. Um dos entrevistados citou a problemática que enfrentava em que havia quatro sócios no negócio, sendo dois fundadores e mais velhos. Havia conflito entre os objetivos dos fundadores e dos sócios mais novos pois os fundadores não queriam crescimento e inovação (queriam estabilidade), enquanto os mais novos sim. Isto fazia com que houvesse objetivos divergentes e muito conflito na tomada de decisão, ou seja, a energia para crescer era desperdiçada nas discussões. Quando o entrevistado foi indagado acerca da perda de oportunidades pela existência destes conflitos ele respondeu que perderam muito, com certeza. Outro entrevistado citou que durante o processo de incorporação de outros sócios, se observou o perfil deles quanto à 
aderência ao próprio perfil em termos de apetite ao crescimento e ao risco do negócio. A aderência possibilitou o crescimento em conjunto;

2) O perfil e objetivos da equipe não estão alinhados com as necessidades organizacionais: relaciona-se à interferência, positiva ou não, do gerenciamento das pessoas que compõem a equipe de trabalho com o próprio resultado organizacional. Este limitador, mais uma vez relacionado a pessoas, foi citado em todas as entrevistas. O entrevistado 2 citou que desde o início do negócio (em sua concepção) visualizou que o time (conjunto de pessoas) seria o limitante ao crescimento, portanto, pensar em perfil, como contratar, remuneração, como criar boas condições de trabalho, tudo isso seria parte de elementos essenciais para o crescimento de sua organização. Já os demais entrevistados complementaram com o fato de que não se ter uma boa gestão de pessoas (em todos os seus processos) pode também ser um fator limitante;

3) Os processos não são padronizados e alinhados com os objetivos organizacionais: diz respeito ao impacto, positivo ou não, da falta de padrão de processos (formais ou não) no resultado do negócio. Existia no roteiro uma pergunta específica para este tema, porém muitos entrevistados citaram espontaneamente este limitador. $\mathrm{O}$ entrevistado 1 citou que este limitador foi identificado (após muitos anos) e estava sendo tratado na época da pesquisa (com uma formalização dos métodos próprios através de manuais). Os entrevistados 3 e 4 seguiram o mesmo caminho. O entrevistado 2 confirmou que perdeu oportunidade de crescimento por falta de padrão em seus processos de trabalho. Os entrevistados 5 e 6 também apontaram este limitador, porém enfatizaram o uso de tecnologias associadas aos processos organizacionais, ou seja, não utilizar ferramentas tecnológicas para garantir padrão de processo é um limitador também de crescimento empresarial;

4) Falta de ferramenta tecnológica adequada para suprir processos e ganho de produtividade: relaciona-se à falta de vínculo entre o uso de ferramentas tecnológicas (por exemplo, as de tecnologia de informação) e o resultado do negócio. Este limitador foi citado por quatro dos seis entrevistados. O não uso de ferramentas de tecnologia da informação, principalmente softwares (sistemas), é um limitador ao crescimento segundo eles. O entrevistado 2 citou o uso de sistemas ERP fortes para garantir a produtividade do pessoal e a qualidade do trabalho; ele pensou em um sistema desde a 
fundação da empresa. O entrevistado 3, que é sócio de uma corretora de investimentos credenciada de grandes instituições financeiras, passou por uma situação de perder todos os dados das transações de seus clientes pois utilizava um software de gestão de relacionamento com clientes $(C R M)$ da instituição que ele representava e não dele próprio. Quando o contrato entre as partes terminou ele acabou perdendo todas as informações dos clientes, ou seja, um grande limitador de seu crescimento. O entrevistado 5 tem utilizado softwares para ganhar produtividade em seus processos de auditoria, ou seja, sem um sistema o trabalho era totalmente manual, realizado por pessoas. Demorava muito tempo e estava sujeito a erros. Para crescer ele precisava crescer a base de funcionários e não era tão fácil dado a busca do perfil ideal e o tempo de capacitação do pessoal (curva de aprendizagem). Após implantar um sistema que realiza estas etapas, ele deu um salto de produtividade. O entrevistado 6 citou um caso semelhante; hoje investe pesado em robôs tecnológicos na área jurídica, para agilizar processos totalmente operacionais;

5) Superalocação do sócio consultor na execução: diz respeito ao uso excessivo da figura do sócio, que também é consultor, na execução de atividades operacionais (como recursos dos projetos e em trabalhos de assessoria), impactando o resultado da empresa. Este limitador foi citado por três dos seis entrevistados. O entrevistado 1 enfatizou a multidisciplinariedade das funções de um sócio da consultoria que é consultor (executa atividades operacionais em projetos) e sócio (investidor e com atribuições funcionais). Principalmente quando ele dedica muito tempo aos projetos e retira tempo de atividades funcionais (pensar o negócio, atividades comerciais, entre outras). Isto pode prejudicar o crescimento do negócio. Já o entrevistado 2 citou que deste o início da empresa pensou em segregar as funções dos sócios e demais da equipe, deixando aos sócios, como diretores da empresa, atividades mais estratégicas (com pouca alocação na operação) e uma equipe operacional para suportar os serviços. O entrevistado 6 citou o exemplo de sua empresa, em que não houve grande crescimento enquanto não houve disposição dos próprios sócios em delegar funções a outras pessoas; dessa forma, eles próprios saíam da operação em si;

6) Limitação da inovação em produtos e processos: relaciona-se à falta de vínculo entre a inovação em produtos e processos com o resultado empresarial. Existia uma pergunta específica sobre este tema, nem todos os entrevistados citaram espontaneamente. $\mathrm{O}$ 
entrevistado 4 citou explicitamente que perdeu clientes por não ampliar o portfólio de produtos. $\mathrm{O}$ entrevistado 5 contou que não obteve um grande crescimento enquanto não ampliou o seu portfólio e não ofertou algo pioneiro ao mercado, focando em contratos maiores;

7) Falta de comunicação assertiva da marca com o mercado: diz respeito à falta de uma boa gestão de marca e comunicação de marca impactando, assim, o resultado do negócio. Não existia uma pergunta específica sobre este item, mas ele foi espontaneamente citado por alguns entrevistados. Segundo o entrevistado 1 é um limitador ao crescimento "a falta de branding adequado", ou seja, não trabalhar a marca de maneira institucional, mas sim apenas trabalhar passivamente o nome dos consultores e o seu relacionamento. $\mathrm{O}$ entrevistado 2 cita a boa gestão de marca como fundamental ao crescimento, ou seja, a sua falta é um limitador identificado;

8) Não ter estrutura física adequada: relaciona-se ao impacto gerado na empresa pela falta de estrutura física (instalações) adequada ao negócio. Nem todos os entrevistados citaram espontaneamente este item, porém todos foram unânimes sobre a importância de ter uma estrutura física adequada e a falta dela como um limitador. Nenhum dos entrevistados passaram pelo que o pesquisador enfrentou de iniciar a empresa sozinho, em sua casa. $\mathrm{O}$ entrevistado 2 citou a grande importância da estrutura física e que ela deve estar associada à demanda. Este mesmo entrevistado citou o trabalho em casa (home-office) apenas para trabalhos operacionais específicos, quando há impossibilidade de ir ao escritório da empresa. O entrevistado 1 falou da importância da estrutura física para receber fisicamente os clientes; a falta dela pode denigrir a imagem empresarial;

9) Não aproveitar todas as oportunidades comerciais: diz respeito à falta de uma boa gestão comercial impactando, assim, o resultado da organização. As citações espontâneas deste limitador foram de quatro dos seis entrevistados, porém está implícito este limitador em muitas das outras respostas fornecidas. Para o entrevistado 1, o conflito entre os sócios impacta o seu processo comercial, que não é bemdelimitado entre os sócios e muito passivo, impactando a geração de novas oportunidades de negócios. O entrevistado 2 deu ênfase ao não uso, em sua totalidade, da boa rede de contatos existente para gerar novos negócios e nem explorar o uso de 
venda cruzada (cross selling), ou seja, também há deficiência no processo comercial. O entrevistado 3 citou o exemplo do $C R M$ utilizado e perda de informação de clientes, ou seja, seu processo comercial não estava utilizando destes dados de forma ativa. $\mathrm{O}$ entrevistado 4 citou como um limitador "a falta de bons parceiros comerciais". O entrevistado 5 cooperou com o caso concreto que havia limitação de acesso a grandes contratos, não conseguia ofertar pois não tinha encontrado os canais e ferramentas corretas. O pesquisador observou também que na maioria dos casos as atividades comerciais (prospecção, geração de oportunidades e fechamento de negócios) ficam sob a responsabilidade dos sócios, portanto, um limitador de tempo é verificado.

Os nove limitadores do crescimento identificados nas entrevistas estão resumidos no quadro-resumo (Fig. 23) abaixo:

Figura 23 - Fatores Limitadores do Crescimento Empresarial

\begin{tabular}{|l|}
\hline \multicolumn{1}{|c|}{ Limitadores do Crescimento } \\
\hline 1- O perfil e objetivos entre sócios não estão alinhados com as necessidades organizacionais; \\
\hline 2- O perfil e objetivos da equipe não estão alinhados com as necessidades organizacionais; \\
\hline 3- Os processos não são padronizados e alinhados com os objetivos organizacionais; \\
\hline 4- Falta de ferramenta tecnológica adequada para suprir processos e ganho de produtividade; \\
\hline 5- Superalocação do sócio-consultor na execução; \\
\hline 6- Limitação da inovação em produtos e processos; \\
\hline 7- Falta de comunicação assertiva da marca com o mercado; \\
\hline 8- Não ter estrutura física a dequada; \\
\hline 9- Não aproveitar todas as oportunidades comerciais. \\
\hline
\end{tabular}
Fonte: Autoria própria (2018).

\subsection{Impulsionadores do crescimento empresarial}

Neste tópico será abordado como os impulsionadores de crescimento foram listados a partir das entrevistas, quais são eles e qual o significado. Além disto, evidenciou-se que os impulsionadores vieram das limitações ou que se relacionam as limitações previamente identificadas.

Após realizar a organização dos nove limitadores do crescimento citados pelos entrevistados, o pesquisador realizou, então, um segundo agrupamento, dos impulsionadores de crescimento evidenciados nas entrevistas. Estes foram organizados em 23 grandes impulsionadores do crescimento empresarial. Neste momento o pesquisador verificou que todos os impulsionadores, na verdade, se relacionavam com um limitador, ou seja, evidenciaram ações para combater uma limitação ao crescimento. Desta forma, a organização 
destes 23 impulsionadores já se deu relacionando-os aos limitadores antes evidenciados. A matriz deste relacionamento ilustra esta relação, ao final deste subcapítulo.

Nos próximos parágrafos serão apresentados os 23 impulsionadores identificados nas entrevistas, assim como o seu significado e o seu relacionamento com o limitador listado. Além disto, serão citados os exemplos práticos (como melhores práticas) evidenciados pelos entrevistados. Os impulsionadores de crescimento serão identificados com um número sequencial dentro do agrupamento do limitador relacionado, ou seja, se o limitador relacionado é de número 2 e o impulsionador citado é o primeiro da lista, então, o seu número é 2.1 .

1) LIMITADOR: O perfil e objetivos entre sócios não estão alinhados com as necessidades organizacionais;

- IMPULSIONADOR 1.1 - Alinhamento anterior à composição da sociedade: importância de uma definição prévia das características necessárias que o sócio precisa ter para atender às necessidades do negócio e realizar um alinhamento antes de estabelecer uma sociedade entre as partes, de forma transparente, trazendo à tona questões quanto a perfil individual, valores pessoais, objetivos pessoais e objetivos em relação ao negócio. Foi constatado nas entrevistas que quando não há uma clareza antes da constituição da sociedade há problemas posteriores que podem impedir o crescimento empresarial. Dois dos entrevistados citaram a existência de programas específicos para inclusão de colaboradores a sócios; estes casos práticos serão citados dentro do limitador de número 2.5, pois trata-se de um sistema de retenção e remuneração de colaboradores;

2) LIMITADOR: O perfil e objetivos da equipe não estão alinhados com as necessidades organizacionais;

- IMPULSIONADOR 2.1 - Ter equipe com competências necessárias: a constatação é de que o negócio possui necessidades específicas quanto a competências essenciais de sustentação e crescimento. O processo de seleção, recrutamento e desenvolvimento de pessoas deve ser capaz de vincular estas competências às necessidades empresariais e não cometer o erro de tentar encaixar as pessoas existentes ao negócio. $\mathrm{O}$ entrevistado 5 deu o exemplo de sua organização. Houve grande mudança quando começou a utilizar 
serviço profissional de recrutadores para garantir que os novos funcionários iriam ter aderência às necessidades da vaga e aos valores empresariais, principalmente quando conquistou o seu primeiro grande contrato e precisou crescer a sua equipe de 14 colaboradores para $50 \mathrm{em}$ um ano. Outro instrumento citado por este mesmo entrevistado é que, como necessita de pessoal com boa qualificação, procura recrutar em universidades com uma chamada de programa de trainee, para atração de talentos. Outro item importante que ele citou foi a implementação formal de avaliação de funcionários com feedback entre líderes e liderados a fim de observar não só desempenho mas quesitos comportamentais dos colaboradores. Além disto, implantou um programa para criação de novos sócios, o "Programa de Trainee a Sócio" (será explicitado detalhadamente no impulsionador 2.5), em que determina o perfil exato dos sócios dentre competências técnicas e comportamentais (ser multifunção, ter formação acadêmica em ciências contábeis, ter habilidade em gestão de pessoas). Desta forma entende-se que ter uma equipe com competências necessárias à organização também envolve os sócios. Isto foi citado pelos entrevistados 2 e 4 , que enfatizaram que o perfil do sócio ou empreendedor é muito importante para impulsionar o crescimento empresarial;

- IMPULSIONADOR 2.2 - Cumprir com os combinados, prover bom ambiente e ferramentas de trabalho: prover condições adequadas para as pessoas produzirem foram apontados como fator impulsionador. Itens como cumprir a palavra (individual de um líder ou manter uma política corporativa), propiciar um bom ambiente (com ações direcionadas de clima organizacional) e prover ferramentas de trabalho adequadas (computadores, instalações, acesso a banco de dados específicos) foram citados. O entrevistado 2 deu bons exemplos práticos sobre este item. Ele disse que, no planejamento da empresa, como foi visto que haveria dependência da equipe (trata-se de uma assessoria contábil), logo foi pensado em fornecer flexibilidade aos funcionários: todos têm computadores móveis (notebooks) caso necessitem trabalhar em casa, o sistema (software) de trabalho pode ser consultado remotamente (da própria residência dos funcionários, caso necessário) e garantido pagamento de horas extras conforme legislação mesmo trabalhando fora do escritório. O entrevistado 4 utiliza-se de ferramentas de engajamento em sua organização para captura de ideias oriundas de seus colaboradores, por exemplo, reuniões periódicas com colaboradores e sócios para compartilhar estratégia e capturar ideias. Isto faz com que se crie um bom ambiente de 
trabalho e com uma cultura voltada à melhoria contínua. O entrevistado 6 , em sua empresa, implantou ações para prover um bom ambiente de trabalho e propício ao desenvolvimento pessoal. Identifica potenciais talentos líderes e fornece cursos específicos, envolve estes potenciais nas decisões com o coaching dos superiores, envolvendo-os em reuniões estratégicas. A identidade corporativa neste organização também permeia o ambiente com ações focadas de clima, com eventos específicos de celebração de aniversariantes e outras datas comemorativas;

- IMPULSIONADOR 2.3 - Uso da liderança como exemplo: o estilo de liderança pelo exemplo foi citado como fator impulsionador na medida que cria uma harmoniosa relação entre líder e liderado e, consequentemente, impacta no grau de motivação dos colaboradores. O entrevistado 2 deu muita ênfase a esta prática que permeia a sua organização. Independente do cargo todos seguem o manual de conduta, os sócios dão o bom exemplo aos seus liderados e os líderes não sócios aos seus liderados. Isto torna o processo legítimo na visão do entrevistado 2. Inclusive este entrevistado passou por um processo de retirar um sócio da sociedade por incompatibilidade de valores, ou seja, não era um bom exemplo para a organização. Os outros entrevistados não expuseram este item explicitamente, porém está nas entrelinhas esta interpretação, na medida que, em sua maioria, todos citaram o alinhamento dos valores pessoais aos valores empresariais como algo fundamental à empresa e, consequentemente, ao seu crescimento;

- IMPULSIONADOR 2.4 - Uso correto da comunicação com colaboradores: a utilização de ferramentas para comunicação formal entre a organização e seus colaboradores, assim como entre os liderados e o seu líder, foi um fator impulsionador citado nas entrevistas. $O$ entrevistado 3 realiza reuniões semanais com toda equipe para compartilhamento de dados de mercado, estratégia vigente e metas semanais. Há um alinhamento entre toda a organização no tocante às atividades importantes para a empresa. Além disto, a meta comercial nesta empresa é do grupo e todos sabem os valores a serem buscados. De uma forma totalmente transparente a empresa compartilha os seus números com a equipe. O entrevistado 4 realiza reuniões semanais entre os sócios para prestação de contas, definição de estratégia e alinhamento de atividades específicas da empresa ou caso específico de cliente, dado que cada sócio cuida de uma função no escritório (é um escritório de advocacia). Cada sócio leva uma comunicação adequada aos colaboradores de sua responsabilidade, de sua equipe. Em sua empresa, o 
entrevistado 5, além de realizar reuniões periódicas com sua equipe, também realiza uma convenção anual com todos os colaboradores da empresa, na qual a organização compartilha com todos o seu planejamento estratégico para aquele ano, com total transparência de números;

- IMPULSIONADOR 2.5 - Retenção através de remuneração variável e programa de inclusão como sócio (meritocracia): o uso de instrumentos formais de remuneração variável e estabelecimento de políticas através de programa para inclusão de colaboradores como sócios foram citados como impulsionadores do crescimento dada a importância dos recursos humanos para as organizações estudadas. O entrevistado 1 citou o uso de remuneração variável para vendas, como comissão sobre vendas, para estimular os sócios a venderem projetos, além dos próprios funcionários. Há uma política específica para isto. O entrevistado 3 cita como um pilar do crescimento a meritocracia, as metas comerciais são para a equipe toda e todos ganham se baterem. Isto é muito transparente na organização. Nesta mesma organização também há um programa específico que permite que funcionários se tornem sócios, é uma ferramenta para retenção de talentos. Para serem elegíveis a se tornarem sócios estes colaboradores devem ser certificados (em certificação específica do segmento de investimentos), ter 2 anos de empresa no mínimo, e terem atingido as metas anuais. Desta forma eles estão aptos a comprarem cotas anualmente, com uma precificação pré-determinada. A validação da entrada na sociedade passa pelo Conselho dos sócios (que é composto por quem tem mais de $1 \%$ da sociedade). Inclusive, anualmente, eles podem transacionar suas cotas, vender e sair da sociedade ou comprar mais participação. Segundo o entrevistado 3, esta prática está sendo muito benéfica para o crescimento da empresa, pois, de outra forma, teria dificuldade de reter os talentos frente aos salários e benefícios das grandes corporações. O entrevistado 5 também tem práticas interessantes. Implantou um programa denominado PDI (Plano de Desenvolvimento Individual) em que avalia e direciona individualmente os colaboradores, inclusive para cargos e salários, em um sistema de meritocracia. Também implantou um programa de participação nos resultados que engloba todos os colaboradores, seus critérios incluem o desempenho geral da empresa, as metas por equipe e as metas individuais. Em 2008, implantou o programa “de trainee a sócio”, programa de retenção de talentos através da sociedade. A empresa possui três categorias de sócios: fundadores, administradores e colaboradores. O perfil da pessoa candidata à sociedade é bem delimitado, como citado 
anteriormente; e são aprovados no conselho de sócios. Dentro desta política a empresa investe em previdência privada aos sócios, quando o sócio chega aos 65 anos de idade ele devolve as cotas, deixa de trabalhar diretamente nos projetos, e resgata a previdência, alterando a categoria de sócio. Ou seja, sempre há renovação e rotatividade dos sócios, com entrada e saída bem-delimitada, sendo um impulsionador ao crescimento desta organização;

- IMPULSIONADOR 2.6 - Ter boa gestão do conhecimento (administração do capital intelectual): dada a importância dos recursos humanos para as organizações estudadas (através das entrevistas cedidas pelos sócios), o estímulo ao estudo e disponibilização de teorias modernas são instrumentos utilizados para impulsionar o negócio. $\mathrm{O}$ entrevistado 5 citou explicitamente como um impulsionador a boa gestão do capital intelectual, oriunda das pessoas. Em sua organização, trabalha com um programa de educação continuada, provendo um sistema estruturado de capacitação de seus colaboradores vinculados ao PDI, já citado, com grande investimento financeiro alocado. Além disto, paga acesso a grandes portais do conhecimento tributário, contábil e jurídico, por exemplo, para fornecer acesso ao conhecimento mais atualizado e ágil possível. O entrevistado 6 , em sua organização, criou um programa para identificar potenciais líderes e, para estes, investe em cursos específicos (para evoluírem tecnicamente) e acompanhamento periódico de um superior em um formato de coaching (para evolução comportamental como futuro líder);

- IMPULSIONADOR 2.7 - Ter estratégia de desenvolvimento de pessoas: ter uma estratégia clara de desenvolvimento de pessoas foi um fator impulsionador citado nas entrevistas. Muitas das iniciativas evidenciadas nas entrevistas foram já citadas nos itens anteriores. Porém, vale ressaltar que por detrás destas iniciativas foi desenhada uma estratégia em que o desenvolvimento de pessoas era colocado como um pilar fundamental, ou seja, pode ser encarado como um impulsionador de crescimento empresarial. Iniciativas como o Programa Formal de Desenvolvimento Individual (PDI), o feedback formal entre líderes e colaboradores, a identidade empresarial permeando a organização e o sistema de valorização das pessoas, identificando potenciais talentos e os desenvolvendo, são evidências de uma estratégia que visa desenvolver pessoas. Além destas, pode-se citar o desenho formal de cargos e salários e as regras desta evolução de maneira bem transparente entre as partes, ou seja, o 
colaborador sabe o que a organização espera dele e o que ele precisa realizar para alcançar crescimento na carreira. Isto foi citado e evidenciado pelo entrevistado 5 .

- IMPULSIONADOR 2.8 - Formação e uso de um gestor: a formação ou introdução de um gestor (ou a competência de administrar o negócio) foi considerada como um fator impulsionador nas entrevistas, principalmente para organizações de origem estritamente técnica. O entrevistado 6 enfatizou muito isto com o exemplo vivenciado em seu negócio. Sua empresa, de origem técnica (advogados), iniciou com 3 sócios e estes faziam de tudo, inclusive atividades operacionais. Ele avalia hoje que isto era um limitador ao crescimento de sua empresa, porém só despertaram quando a empresa passou por uma situação financeira delicada e não conseguiram enxergar onde estava o problema financeiro. Desta forma, decidiram contratar um gestor com competência administrativa (que não era completa na organização até aquele momento). Para tanto, tiveram disposição em delegar atividades para este novo gestor e autonomia para ele realizar diagnóstico e propor novas políticas. Assim, nasceu um novo quadro de processos e políticas administrativas, incluindo uma primeira versão do sistema de governança corporativa, além de ter retirado os sócios da operação. Isto, conforme o entrevistado 6, foi fundamental ao crescimento do negócio;

3) LIMITADOR: Os processos não são padronizados e alinhados com os objetivos organizacionais;

- IMPULSIONADOR 3.1 - Mapeamento e formalização de processos em manuais: a formalização de atividades, procedimentos e políticas foi citada como uma boa prática em termos de se tornar um impulsionador de crescimento. Existia uma pergunta específica sobre este item e foi unanimidade entre os entrevistados que ter iniciativas para padronizar processos e garantir que eles estejam alinhados aos objetivos da empresa são impulsionadores ao crescimento da organização. O entrevistado 1 citou que em sua empresa contrataram um profissional específico para mapear os processos e os métodos específicos de trabalho e formalizar em um manual. Este manual é parte integrante de um processo de treinamento de novos colaboradores, para garantir que o método de trabalho utilizado é o pertencente à empresa e não realizado com iniciativas individuais. Os entrevistados 3 e 4 implantaram a mesma ação do entrevistado 1. O entrevistado 5 acrescentou aos tópicos evidenciados pelos anteriores a introdução de 
ferramentas tecnológicas associadas ao processo. O exemplo da empresa dele é o uso de um sistema em que a metodologia da prestação de serviço (no caso, auditoria contábil) está cadastrada no sistema, e este garante que os colaboradores seguirão os passos necessários ao processo. Além disto, a ferramenta automatiza uma série de análises que antes eram realizadas por recursos humanos, reduzindo o tempo de análise e os erros. Foi comprovado ganho de produtividade com esta ação. O entrevistado 6 também aplicou ações semelhantes ao entrevistado anterior, inclusive tem uma equipe própria de desenvolvimento de sistemas que visa construir sistemas integradores para automatizar tarefas repetitivas através de robôs;

4) LIMITADOR: Falta de ferramenta tecnológica adequada para suprir processos e ganho de produtividade;

- IMPULSIONADOR 4.1 - Uso de ferramentas tecnológicas: a utilização de ferramentas tecnológicas (em sua maioria softwares) para ganho de produtividade e integração aos processos foi citada como um impulsionador de crescimento empresarial. Este item foi destacado à parte apesar da maioria das iniciativas terem sido citadas anteriormente. Apenas destaca-se que o uso de ferramentas tecnológicas não se limita aos sistemas já citados, porém deve permear toda organização em seus processos fundamentais, para garantir produtividade e registro de transações;

5) LIMITADOR: Superalocação do sócio consultor na execução;

- IMPULSIONADOR 5.1 - Delimitar atividades operacionais e estratégicas: foi citado no sentido de segregar atividades estratégicas dos sócios das operacionais quando o mesmo indivíduo executa atividades relacionadas à própria operação, por exemplo, ser parte integrante de um projeto a cliente, como um recurso do projeto. $\mathrm{O}$ entrevistado 2 citou exemplos claros destas iniciativas em que, desde a fundação da empresa, delimitou as atividades que ficariam com os dirigentes (aos sócios, seriam as atividades estratégicas) e os outros colaboradores (aos não sócios, seriam as atividades operacionais), dado que acreditava que se não houvesse esta delimitação os próprios sócios seriam gargalos ao crescimento da empresa. Isto foi realizado com sucesso, permitiu que os sócios viessem, inclusive, a avaliar outras oportunidades de investimento em outras empresas e dedicar parte do tempo à primeira organização. $O$ entrevistado 1 também citou a necessidade de 
segregação destas atividades, principalmente entre os sócios fundadores e os sócios mais novos. Depois que os sócios mais novos tiveram mais autonomia em algumas funções, como a comercial, a empresa pôde crescer de maneira mais estruturada. $\mathrm{O}$ exemplo já citado pelo entrevistado 6, em que trouxe um gestor para o negócio (sendo não sócio) e delegou funções antes dos sócios, fez com que os sócios se liberassem das atividades operacionais e se dedicassem à estratégia, propiciando, assim, crescimento ao negócio.

- IMPULSIONADOR 5.2 - Disposição em delegar atividades (pelos sócios): muitas vezes é difícil para o sócio, principalmente o fundador, delegar certas atividades que sempre foram conduzidas por ele. Desta forma, a disposição em delegar atividades (para ganho de tempo e produtividade) foi citada como fator impulsionador de crescimento. $\mathrm{O}$ melhor exemplo foi citado pelo entrevistado 6, já explicitado nos tópicos anteriores;

6) LIMITADOR: Limitação da inovação em produtos e processos;

- IMPULSIONADOR 6.1 - Uso de aprendizado rápido em projetos: utilizar a própria vivência dos recursos humanos da empresa em suas atividades operacionais trazendo para dentro da organização críticas e sugestões de melhoria para os próximos projetos ou para o próprio produto ou serviço é um fator impulsionador citado em entrevista. $\mathrm{O}$ entrevistado 1 citou um bom exemplo acerca disto. Ele explicou que, em todo projeto, visualiza pontos de melhoria no processo de consultoria. Estes pontos são trabalhados para que, no próximo projeto similar, já entre em operação em um formato de teste ágil, ou seja, já testa em ambiente real se a melhoria é positiva ou não em termos de resultado. Se sim, é incorporada ao método oficial da consultoria. Isto possibilitou evoluções rápidas na metodologia e é citado como um impulsionador;

- IMPULSIONADOR 6.2 - Processo para obter ideias dos próprios colaboradores: utilizar ferramentas formais para estimular as ideias dos colaboradores foi uma boa prática citada na maioria das entrevistas. O entrevistado 4 utiliza na prática uma ferramenta para tal. Em suas reuniões periódicas com a equipe busca estimular a citação de melhorias em sua operação ou em contatos com os clientes. Há uma área comercial que também traz ideias de fora para dentro. São debatidas e, se aprovadas, incorporadas à organização. $\mathrm{O}$ entrevistado 5 também tem uma área comercial e de marketing que 
alimenta a organização com ideais oriundas do mercado, ou capturadas através dos clientes ou de mudanças na legislação brasileira. Estas são debatidas nas reuniões específicas de trabalho;

- IMPULSIONADOR 6.3 - Ser pioneiro é importante: ser o primeiro a oferecer certo tipo de serviço ao mercado foi um fator impulsionador citado nas entrevistas, principalmente para conquista de vantagem competitiva. $\mathrm{O}$ entrevistado 5 possui um processo claro para tratar esta questão. Em seu quadro de colaboradores possui diversos estudiosos e pesquisadores (alguns professores) que estão na vanguarda do conhecimento em seu campo de atuação. A postura é de antecipar as mudanças, portanto, a sua área comercial, de marketing e os profissionais técnicos são avisados de qualquer alteração na legislação vigente ou indicativos de que isso possa ocorrer. Desta forma, eles se antecipam em pensar produtos e serviços para serem oferecidos ao mercado, com reuniões periódicas e específicas sobre o tema, e implantam essas medidas com uma postura ativa de comunicação ao mercado. Estas ações possibilitaram um crescimento avantajado ao longo da história desta organização;

7) LIMITADOR: Falta de comunicação assertiva da marca com o mercado;

- IMPULSIONADOR 7.1 - Uso da rede de contatos de forma estratégica: utilizar rede de contatos (clientes, potenciais clientes, parceiros, fornecedores) para estimular os negócios é uma prática considerada de impulsionamento do crescimento organizacional. $\mathrm{O}$ entrevistado citou esta prática como um impulsionador ao crescimento, porém não evidenciou-a com casos práticos, a não ser citando que a maioria dos negócios surge de indicações de sua rede de contatos. O entrevistado 4 citou o uso da rede de parceiros estratégicos para geração de indicações de negócios, e possui uma rede de profissionais correlatos que indicam negócios complementares ao seu. Os entrevistados 3,5 e 6 utilizam de participação em grupos de negócio (de relacionamento) e associações como estratégia comercial de geração de oportunidades de novos negócios através destas redes de parceiros;

- IMPULSIONADOR 7.2 - Tangibilizar resultados para clientes: citado como fator impulsionador o processo de tornar tangível todos os resultados dos serviços e produtos entregues. $\mathrm{O}$ entrevistado 1 exemplificou citando que em sua empresa eles procuram 
entregar "além da expectativa" dos clientes através dos materiais eletrônicos ou impressos disponibilizados e reuniões presenciais de entrega com um conteúdo excelente. Já o entrevistado 6 utiliza-se da transparência com o cliente para tornar mais tangível a entrega de seu serviço. Citou que, ao menor problema que ocorre em sua operação, o cliente é acionado e compartilha-se o que está ocorrendo e o que está sendo feito para solucionar a questão. Não há prática de justificar o problema, mesmo se for extremamente crítico. Esta política tem gerado um índice de retenção e fidelização altíssimo em suas plataformas, possibilitando, assim, o crescimento empresarial;

8) LIMITADOR: Não ter estrutura física adequada;

- IMPULSIONADOR 8.1 - Adequação da estrutura física: a separação entre ambiente físico residencial e profissional foi citado como um fator impulsionador. Nenhum dos entrevistados passaram pelo o que o pesquisador passou em seu início empresarial, começar sozinho e trabalhando em casa. Porém todos são unanimes em falar da importância de ter um ambiente físico profissional e separado da residência. Todos os entrevistados possuem estrutura física em suas empresas. $O$ entrevistado 1 cita o uso do espaço para receber clientes e reforçar a imagem da empresa (pode ser um potencial cliente também). O entrevistado 2 cita como um impulsionador extremamente importante a organização. Os demais entrevistados utilizam também da estrutura física para emplacar ações de bom clima e ambiente corporativo aos seus colaboradores;

9) LIMITADOR: Não aproveitar todas as oportunidades comerciais;

- IMPULSIONADOR 9.1 - Uso intensivo de venda cruzada: aproveitar as oportunidades de vendas de outros serviços ou produtos em clientes já conquistados é um fator impulsionador. Não basta ampliar o portfólio de produtos e serviços, mas tem que vender a maior parte deste portfólio aos clientes existentes, ou seja, realizar venda cruzada (cross selling). O entrevistado 2 cita este impulsionador como muito importante. Em sua empresa há um esforço para comunicar aos clientes atuais que eles realizam mais do que está contratado, ou seja, fazer o cliente conhecer todo o portfólio. O entrevistado 5 cita que em sua empresa a comunicação de novos produtos e serviços ocorre aos seus clientes já direcionando para aqueles que possuem perfil para consumo 
(no caso deles muito orientado a mudanças na legislação e cumprimento de obrigações com o governo);

- IMPULSIONADOR 9.2 - Uso de processos e ferramenta de CRM para retenção das informações: o uso de ferramentas formais de registro de dados e transações de clientes para posterior uso (como informação pertencente à empresa e não a terceiros) foi citado como um fator impulsionador. Já citado o caso ocorrido com o entrevistado 3, que perdeu todas as informações de seus clientes quando rompeu contrato com uma grande instituição financeira pois os dados de clientes eram registrados no CRM deles e não em um próprio. A ação desenhada foi de implantar um software de CRM próprio. Atualmente todos os contatos com o cliente são registrados nesta plataforma, garantindo um registro de $100 \%$ do histórico de transações e de perfil. Com isto, utiliza-se destes dados para traçar ações de relacionamento com os clientes, por exemplo, em um convite para um evento (palestra técnica específica) disparado aos clientes propensos em adquirir determinado serviço;

- IMPULSIONADOR 9.3 - Uso estratégico de parceiros comerciais: pensar a rede de parceiros comerciais, muitas vezes complementares às competências existentes no negócio, de forma estratégica, é um fator impulsionador. É uma ação comum a alguns entrevistados para possibilitar ampliação do portfólio de produtos e serviços. Para os serviços que não são prestados diretamente pela empresa, ou quando não há competência técnica para tal, busca-se profissionais de mercado e credencia-se eles para realizarem o serviço pela empresa, em um formato de terceirização. A comercialização continua pela empresa original, assim como o contato de atendimento com o seu cliente. Pode-se também praticar apenas a indicação comercial, também é comum este desdobramento. Esta prática é utilizada em todas as organizações relacionadas aos entrevistados;

- IMPULSIONADOR 9.4 - Estratégia para acessar maiores contratos: foi citado como fator impulsionador o fato de ter uma estratégia específica para acessar e conquistar contratos maiores. É um modo de crescer em uma escala maior. Foi citado explicitamente pelo entrevistado 5. A sua organização se credenciou em um grande portal setorial e se tornou um prestador de serviço oficial deles, ou seja, comercialmente se uniu a marca maior (do portal) para gerar e atrair grandes demandas. Estas demandas, 
oriundas de transformações da legislação, ocorreram, e a empresa já estava apta a capturar estes serviços (pessoal capacitado, sistema instalado, processo definido). Esta associação, incluindo plataformas tecnológicas já citadas, possibilitou grande crescimento da empresa em questão.

Foram apresentados todos os impulsionadores de crescimento citados nas entrevistas, agrupados de forma associada aos limitadores e com exemplos práticos citados pelos profissionais. Abaixo (Fig. 24) segue quadro-resumo deste agrupamento: 
Figura 24 - Quadro Limitadores e Impulsionadores

\begin{tabular}{|c|c|c|}
\hline $\begin{array}{l}\text { Limitadores do Crescimento (originados na teoria e } \\
\text { entrevistas) }\end{array}$ & $\begin{array}{l}\text { Impulsionadores do Crescimento (originados nas } \\
\text { entrevistas) }\end{array}$ & Exemplos práticos citados nas entrevistas (Iniciativas) \\
\hline $\begin{array}{l}\text { 1- O perfil e objetivos entre sócios não estão alinhados } \\
\text { com as necessidades organizacionais }\end{array}$ & 1.1 - Alinhamento anterior a composição da sociedade & $\begin{array}{l}\text { É observado isso antes de compor o quadro societário (perfil: ser multifunção, formação acadêmica } \\
\text { em ciências contábeis, ter habilidade em gestão de pessoas). }\end{array}$ \\
\hline \multirow{8}{*}{$\begin{array}{l}\text { 2- O perfil e objetivos da equipe não estão alinhados } \\
\text { com as necessidades organizacionais }\end{array}$} & 2.1 - Ter equipe com competências necessárias & $\begin{array}{l}\text { Ajuste no processo de recrutamento e seleção com apoio de terceiro capacitado. Vagas em } \\
\text { Universidades com chamada de Trainee }\end{array}$ \\
\hline & $\begin{array}{l}\text { 2.2 - Cumprir com os combinados, prover bom } \\
\text { ambiente e ferramentas de trabalho }\end{array}$ & $\begin{array}{l}\text { Flexibilidade funcionários trabalhar fora, sistema forte, pgto hora extra, benefícios adequados. } \\
\text { Estratégias de bom clima organizacional (ambiente familiar) }\end{array}$ \\
\hline & 2.3 - Uso da liderança como exemplo & \\
\hline & 2.4 - Uso correto da comunicação com colaboradores & $\begin{array}{l}\text { Reunião semanal, uso de avaliação de desempenho, convenção anual (planejamento estratégico } \\
\text { compartilhado e comunicados entre todos) }\end{array}$ \\
\hline & $\begin{array}{l}2.5 \text { - Retenção através de remuneração variável e } \\
\text { programa de inclusão como sócio (Driver } \\
\text { meritocracia) }\end{array}$ & $\begin{array}{l}\text { Uso meta grupo, programa de entrada e saída como sócios (elegíveis). Programa de participação nos } \\
\text { resultados (leva em consideração o desempenho geral da empresa, depois metas por equipe, metas } \\
\text { individuais). Prover sociedade como instrumento de retenção: programa treinee a sócio - colaborador } \\
\text {, tem } 3 \text { categorias de sócios (fundadores, administradores e colaboradores). Investe previdência } \\
\text { privada , } 65 \text { anos devolve cotas e resgata previdência. }\end{array}$ \\
\hline & $\begin{array}{l}\text { 2.6 - Ter boa gestão do conhecimento (administração } \\
\text { do capital intelectual) }\end{array}$ & Programa de educação continuada, pagamento de plataformas de conhecimento \\
\hline & 2.7 - Ter estratégia de desenvolvimento de pessoas & $\begin{array}{l}\text { Programa formal de desenvolvimento individual (PDI), feedback líderes e colaboradores - } \\
\text { formalizado. identidade empresarial e valorização das pessoas. identificar potenciais, envolver } \\
\text { potenciais líderes em decisões, coaching }\end{array}$ \\
\hline & 2.8 - Formação e uso de um gestor & $\begin{array}{l}\text { Instrumentos usados para sócio sair da operação: em } 2013 \text { trouxe um gestor para dentro da } \\
\text { organização (introduzir políticas e processos. Nasceu uma governança). O gatilho foi não enxergar } \\
\text { onde estava o problema financeiro. Instituiu governança corporativa. Políticas em geral. Equipe: um } \\
\text { bom gestor é fundamental para o crescimento. É o fator primordial. }\end{array}$ \\
\hline $\begin{array}{l}\text { 3- Os processos não são padronizados e alinhados com } \\
\text { os objetivos organizacionais }\end{array}$ & $\begin{array}{l}\text { 3.1 - Mapeamento e formalização de processos em } \\
\text { manuais }\end{array}$ & Uso de terceiros para apoio. Implantação de formulários e criação de rotinas \\
\hline $\begin{array}{l}\text { 4- Falta de ferramenta tecnológica adequada para } \\
\text { suprir processos e ganho de produtividade }\end{array}$ & 4.1 - Uso de ferramentas tecnológicas & $\begin{array}{l}\text { Ferramenta IOB para advogados. Tem uma ferramenta para absorver transações, uso reduzido de } \\
\text { tempo operacional e elevação ana'litica. De } 5 \text { anos para cá, uso de ferramenta na auditoria para o } \\
\text { trabalho do auditor (busca arquivos contábeis, metodologia cadastrada no sistema. Ferramentas } \\
\text { tecnológicas são usadas fortemente para padrão de processos, investimento forte em sistemas. }\end{array}$ \\
\hline \multirow{2}{*}{ 5- Superalocação do sócio-consultor na execução } & 5.1 - Delimitar atividades operacionais e estratégicas & \\
\hline & 5.2 - Disposição em delegar atividades (pelos sócios) & \\
\hline \multirow{3}{*}{ 6- Limitação da inovação em produtos e processos } & 6.1 - Uso de aprendizado rápido em projetos & Consultor traz para dentro da organização ideias e as implementa, realizando testes rápidos \\
\hline & $\begin{array}{l}\text { 6.2 - Processo para obter ideias dos próprios } \\
\text { colaboradores }\end{array}$ & $\begin{array}{l}\text { existe uma área comercial / marketing, reuniões periódicas com sócios e lideres a fim de atualizar } \\
\text { produtos e entrada de novos (vem dos clientes e mudanças dalegislação). }\end{array}$ \\
\hline & 6.3 - Ser pioneiro é importante & $\begin{array}{l}\text { Atenção ao mercado e alterações. Ser pioneiro é muito importante. Estudiosos (12 professores e } 10 \\
\text { instrutores da IOB), estar na vanguarda. Antecipar as mudanças legais. }\end{array}$ \\
\hline \multirow{2}{*}{$\begin{array}{l}\text { 7- Falta de comunicação assertiva da marca com o } \\
\text { mercado }\end{array}$} & 7.1 - Uso da rede de contatos de forma estratégica & \\
\hline & 7.2 - Tangilizar resultados para clientes & Uso da transparência na comunicação \\
\hline 8- Não ter estrutura física adequada & 8.1 - Adequação da estrutura física & \\
\hline \multirow{4}{*}{ 9- Não aproveitar todas as oportunidades comerciais } & 9.1 - Uso intensivo de venda cruzada & \\
\hline & $\begin{array}{l}\text { 9.2 - Uso de processos e ferramenta de CRM para } \\
\text { retenção das informações }\end{array}$ & \\
\hline & 9.3 - Uso estratégico de parceiros comerciais & \\
\hline & 9.4 - Estratégia para acessar maiores contratos & grandes plataformas e certificadoras para credenciamento \\
\hline
\end{tabular}




\subsection{Iniciativas para crescimento empresarial - plano de intervenção}

Neste tópico será abordado como os impulsionadores de crescimento que foram listados a partir das entrevistas tornaram-se iniciativas explícitas para combater os limitadores de crescimento empresarial. A partir destas iniciativas, criou-se um plano de intervenção a fim de ser aplicado na empresa DHoffmann Consultoria. Este tópico visa atender ao objetivo secundário que é "elaborar uma sistematização das iniciativas que irão suplantar as limitações identificadas e possibilitarão o crescimento da consultoria e assessoria empresarial para validação posterior". Será visto, inclusive, que algumas iniciativas já foram implantadas e os resultados serão demonstrados. As demais serão aplicadas posteriormente a esta pesquisa devido ao tempo disponível para tal, porém fazem parte do plano de intervenção ou da sistematização das iniciativas.

O pesquisador elencou 17 iniciativas (que neste material estão classificadas com letras, de A a Q, em ordem alfabética) que compõem o plano de intervenção na empresa em que é sócio, a DHoffmann Consultoria. Estas iniciativas partiram dos 23 impulsionadores citados no tópico anterior e dos exemplos angariados em cada um deles. Foi ponderada a aplicabilidade de cada um deles, conforme a estrutura atual da empresa e grau de maturidade, portanto, foram consideradas para o plano as iniciativas com possibilidade de aplicação nos próximos 12 meses posteriores a esta pesquisa, para garantir a aplicação e mensuração dos resultados.

A seguir seguem as descrições e detalhamento para cada uma das 17 iniciativas mapeadas neste plano de intervenção:

a) Substituição de recursos sem experiência por recurso sênior e com competência associada à vaga (relaciona-se com o impulsionador 2.1): É necessário ao negócio ter uma equipe com competência adequada aos objetivos do negócio. $\mathrm{O}$ objetivo do pesquisador em sua empresa é de crescer com consistência, garantindo alta qualidade nas entregas dos atuais clientes e dos novos. Mas como realizar isso se não existir tempo disponível para tal e equipe competente para realizar as entregas? Como visto no relato da experiência do pesquisador, para combater o problema de recursos humanos limitados (pois o pesquisador como consultor era um recurso único e exclusivo), utilizou-se da contratação de pessoas sem experiência (como estagiários), em uma tentativa de formá-los em atividades operacionais e apoiar o trabalho do consultor. O consultor, em suas diversas 
atividades, executa visitas presenciais em clientes (muitas vezes denominadas atividades de campo), que consomem muito tempo, e também tem necessidade de exercer diversas atividades no escritório, tais como: planilhar dados coletados em campo, formalizar atas das reuniões, realizar análise de dados, formatar materiais e apresentações para uso no cliente, entre outras. Estas atividades de cunho operacional consomem muito tempo e poderiam ser realizadas por outras pessoas que não o consultor, isto visando ganhar produtividade no tempo do consultor. O profissional sem experiência que o pesquisador contratou foi formado para tais atividades e aos poucos dominou a maioria. O consultor utilizou de tempo para formá-lo, tempo já escasso. O resultado já citado foi a perda deste esforço de formação pela saída do funcionário do quadro (pois foi trabalhar em outra empresa ganhando um salário um pouco maior). Isto sucedeu duas vezes. Como intervenção já realizada durante o processo desta pesquisa foi a contratação de um profissional experiente nestas funções. O pesquisador buscou um profissional com o qual já tinha trabalhado em seu último vínculo empregatício, ou seja, já conhecia a pessoa, sua índole e sua capacidade técnica. O salário inicial foi cerca de quatro vezes maior que um profissional sem experiência, porém já iniciou pronto na função. $\mathrm{O}$ resultado observado pelo pesquisador foi que não necessitou formá-lo nas atividades, ou seja, não desprendeu de tempo para tal. As atividades operacionais foram absorvidas por este profissional e isto fez com que o tempo do consultor fosse maximizado, ou seja, o tempo para atividades operacionais foi reduzido drasticamente ampliando o uso do tempo em atividades mais complexas, como reuniões em clientes e atividades de relacionamento empresarial. Além disto, este recurso pôde contribuir com novas ideias, que se reverteram em alguns ajustes nos serviços prestados, inclusive na elevação dos preços praticados. Este profissional agora está sendo formado para ser um futuro consultor também;

b) Uso de consultoria especializada para prover líderes com ferramentas motivacionais associadas à clima e ao desenvolvimento pessoal da equipe, associando-a à estratégia (relaciona-se com o impulsionador 2.2, 2.3, 2.7 e 5.2): esta é uma intervenção realizada parcialmente e que é muito importante. Relaciona-se com diversos impulsionadores coletados nas entrevistas: cumprir com os combinados, prover bom ambiente e ferramentas de trabalho, uso da liderança como exemplo, ter estratégia de desenvolvimento de pessoas e disposição em delegar atividades (pelos sócios). 
Esta ação visa combater os limitadores: o perfil e objetivos da equipe não estão alinhados com as necessidades organizacionais e superalocação do sócio consultor na execução. Como prestação de serviço há a necessidade e dependência dos recursos humanos para execução das atividades. Foi visto, no item anterior, a intervenção de mudar o perfil de contratação dos recursos humanos da DHoffmann Consultoria e alguns resultados positivos observados. Porém, não adianta apenas contratar, é necessário garantir uma boa gestão destes recursos pautada no desenvolvimento das pessoas e associada aos objetivos do negócio, em uma relação ganha-ganha. A DHoffmann Consultoria não possui uma expertise em gestão de recursos humanos, apesar da experiência prática de seu pesquisador, que foi gestor de equipe em grande organização. Como citado em algumas entrevistas, o uso de profissionais externos especialistas nesta área foi de fundamental importância para diagnosticar necessidades, traçar estratégia e apoiar implantação de ações visando desenvolver pessoas, criar um bom clima de trabalho e criar alavancas motivacionais para o negócio. Na DHoffmann Consultoria não há problema de clima organizacional, existe um bom clima. O fato é que o consultor não consegue ter muito tempo disponível para investir, de forma mais intensa, no direcionamento de seus recursos quanto ao desenvolvimento pessoal (seja comportamental ou técnico) de forma estruturada (com método profissional aplicado). O consultor, através de sua rede de contatos, conhece bons especialistas nesta área, inclusive um deles já realiza alguns serviços dentro de projetos da DHoffmann Consultoria direcionados a clientes. O pesquisador contratou este profissional já para a realização de testes comportamentais com sua equipe, para ser uma das etapas de diagnóstico, e foi constatado, além do perfil individual do colaborador, pontos de estresse e alavancas motivacionais. Com isto, já pode utilizar de alguns dados para estabelecer um novo sistema de remuneração do colaborador, mais adequado ao perfil identificado. No plano de intervenção, nesta ação discutida, há o interesse de realizar um acompanhamento periódico por parte deste especialista com a equipe da DHoffmann Consultoria, com um olhar de desenvolvimento frente aos objetivos empresariais já traçados, incluindo novas contratações e os próprios sócios. Espera-se com esta ação garantir que os valores da empresa sejam permeados entre a equipe e um desenvolvimento de longo prazo, para suprir a necessidade de inovação em serviço, qualidade das entregas e retenção de talentos;

c) Uso de reunião mensal para discussão estratégica (relaciona-se com o impulsionador 2.4): esta ação também se relaciona com os impulsionadores ligados a pessoas. Alguns 
entrevistados citaram o uso de ferramentas formais de comunicação com seus colaboradores a fim de garantir a disseminação correta das informações e engajamento por participarem também de algumas decisões. No âmbito da empresa pertencente ao pesquisador, existe uma pequena equipe composta por quatro pessoas, ou seja, a comunicação é mais fácil. Mas isto não faz com que não se crie um momento para tal, é necessário realizar a comunicação de forma formal e com método, associado a um objetivo claro. Com a entrada do profissional mais maduro em seu quadro de colaboradores, já se iniciou a realização de reuniões para tratar de temas mais estratégicos como: otimizar alguns processos internos e pensar novos serviços ou posicionamento. Porém, esta reunião não é tratada como algo periódico e isto faz com que não se dê ritmo adequado à implantação de ações mapeadas ou discussões estratégicas. Portanto, esta iniciativa é muito importante e faz parte do plano de intervenção. O resultado esperado é a aceleração da implantação de ações já mapeadas e do número de novas ideias, além disto, espera-se engajar os colaboradores através da participação ativa da estratégia empresarial. Um resultado interessante já observado de reuniões realizadas (durante o processo desta pesquisa) foi a alteração do modo de precificação de serviços (e este propiciou incremento da receita) e também um desenho para um novo serviço a ser vendido;

d) Desenho de remuneração variável (relaciona-se com o impulsionador 2.5): esta iniciativa foi muito citada pelos entrevistados, incluindo o uso de programas para tornar colaboradores em sócio. A meritocracia por trás disso foi evidenciada em diversos exemplos, incluindo resultados concretos. Esta iniciativa também visa a retenção de talentos na empresa. Para a DHoffmann Consultoria é fundamental esta iniciativa para garantir não apenas a retenção de talentos mas a alavanca motivacional deles em relação aos objetivos da empresa. Porém, este desenho da remuneração variável deve ser realizado de forma assertiva, para garantir estímulo aos colaboradores e ser viável financeiramente, ou seja, aumentar as margens do negócio para ter o que repartir com sua equipe. Existe uma ideia para um sistema que premie a captura de novos negócios, a participação em projetos, a qualidade de entrega em projetos e o desenvolvimento pessoal, mas ainda não foi implantada por questão do tempo disponível; 
e) Programa de Incentivo a Educação com uso de bolsa de ensino (relaciona-se com o impulsionador 2.6): iniciativas do tipo foram citadas pelos entrevistados; um deles citou a importância da administração do capital intelectual. Em uma consultoria deve existir esta preocupação, sendo este seu principal ativo disponível. Esta iniciativa ainda não foi implantada, mas há a ideia de criar um programa de incentivo ao estudo (com subsídio da empresa) de conhecimentos complementares ao do pesquisador e que devem ser revertidos em novos produtos e serviços da empresa. Também espera-se que seja uma ferramenta de retenção de talentos na medida que se torna um benefício complementar aos já oferecidos. Esta iniciativa deve estar totalmente aliada às iniciativas $B$ e D já citadas, ou seja, dentro de um plano de desenvolvimento pessoal maior e com relação às questões relacionadas à remuneração;

f) Formação do recurso familiar para absorver atividades gerenciais (relaciona-se com o impulsionador 2.8): esta iniciativa relaciona-se com o impulsionador "formação e uso de um gestor" e com as iniciativas relacionadas a pessoas já citadas. Como já tratado neste documento, a esposa do pesquisador trabalha conjuntamente com ele na empresa e traz diversos benefícios por conta disso. Um deles é o fato de ser uma pessoa de confiança dentro da organização, com tempo disponível e com potencial para absorver novas funções e atividades. Atualmente realiza atividades financeiras básicas (contas a pagar e contas a receber) e algumas administrativas e comerciais. Com esta iniciativa espera-se formá-la como um recurso gerencial, capaz de exercer todas as atividades administrativas e comerciais, liberando tempo do consultor principal para outras atividades. Para tal é necessário capacitá-la em atividades nunca exercidas, com treinamentos direcionados, de acordo com o plano de desenvolvimento citado na iniciativa $\mathrm{B}$;

g) Primeiro mapeamento para processos operacionais básicos (relaciona-se com o impulsionador 3.1): como citado pelos entrevistados é fundamental ter os processos da empresa muito bem mapeados. Uma para garantir replicação destes (em caso de troca de pessoas que os exerce, por exemplo) e outra para pensar sobre como torná-los mais eficientes. Esta iniciativa foi realizada durante esta pesquisa com os processos operacionais básicos relacionados a clientes. Para alguns clientes em fase de assessoria, 
ou seja, de acompanhamento, é natural que a consultoria realize algumas atividades de forma rotineira para apoiar seus clientes, por exemplo, atualizar algum tipo de relatório periodicamente. Esta é uma rotina e foram registradas em forma de procedimento padrão as etapas de realização destas atividades. Um exemplo de seu uso foi quando um colaborador saiu da empresa e o outro pode realizar a mesma atividade com o uso deste documento. Ou seja, foi verificada a replicação da atividade com múltiplos recursos humanos, tirando a dependência da pessoa e focando na atividade. Esta iniciativa deve ser levada a todos os processos da DHoffmann Consultoria;

h) Formação do Manual de Políticas e Processos da Empresa (relaciona-se com o impulsionador 3.1): esta iniciativa relaciona-se com a anterior. Não basta mapear e documentar alguns processos, é importante realizar a documentação de todos os processos e incluí-los em algo maior, em um grande manual de atividades e processos. Este deve refletir o método próprio da consultoria agir e aplicar seus serviços. Além disto, verificase que é importante também registrar as políticas da empresa contendo o que é aceitável ou não em termos de comportamento e especificidades técnicas da operação. Isto garante, inclusive, uniformidade da comunicação, conforme relato dos entrevistados. Por isso que esta iniciativa faz parte do rol do plano de intervenção para combater o limitador de crescimento "os processos não são padronizados e alinhados com os objetivos organizacionais", dado que hoje os métodos de consultoria da empresa não estão totalmente documentados e eles fazem parte da grande riqueza dela, visto que há a necessidade de se ter mais clareza para os clientes e de treinar os novos funcionários;

i) ERP básico para processo financeiro (relaciona-se com o impulsionador 4.1): o limitador de crescimento associado a esta iniciativa é a "falta de ferramenta tecnológica adequada para suprir processos e ganho de produtividade". Foi constatado em entrevistas o uso de ferramentas tecnológicas para combater tal limitador, sistemas ERP propiciaram ganhos de produtividade em suas operações, entre outros sistemas citados, tais como CRM e integradores do conhecimento. Durante esta pesquisa, foi implantado um pequeno ERP na DHoffmann Consultoria, visando informatizar o processo de contas a pagar e receber. Foi escolhido um sistema pequeno (porém bem conhecido) via web (cloud computing), 
amplamente utilizado em micros e pequenas empresas, que é acessível financeiramente pois paga como um serviço (modalidade system as a service). Existia uma janela de tempo para teste gratuito de 1 mês, porém não foi utilizado na íntegra, ocorrendo uma contratação baseada em uma promoção de preço agressiva. Foi feito um contrato de 12 meses. A implantação foi realizada por duas pessoas da empresa e o pesquisador não participou. Gastou-se um tempo da equipe na realização de cadastros, integrações com sistemas bancários e inclusão de transações. Depois de um tempo constatou-se que o sistema tinha falhas e não propiciaria os ganhos de produtividade esperados. Um deles era o processo de conciliação bancária, que deveria ocorrer com integração total do sistema ao banco e que, na prática, não ocorreu. Diversos registros não eram incluídos automaticamente no sistema, gerando um retrabalho manual para a equipe da consultoria. Foi uma má escolha, o sistema já foi descontinuado. Porém, essa não é uma má iniciativa, muito pelo contrário. A intenção é de escolher um ERP apropriado ao negócio ou correr com processos básicos em planilhas eletrônicas (não são muitas transações requeridas). Mas o principal é escolher uma ferramenta que possibilite aumentar a produtividade operacional em atividades com clientes, no registro de ações, ata, abertura de chamados, disponibilidade de dados, entre outros. Já houve abordagem de um fornecedor de sistema semelhante e o assunto está sendo tratado. Esta iniciativa é muito importante para o futuro do negócio e está no plano de intervenção;

j) Implantação de sistema para controle de fluxos de trabalho e interação com clientes (relaciona-se com o impulsionador 4.1 e 9.2): esta intervenção é complementar à anterior. Os entrevistados deixaram claro que é importante utilizar sistemas de tecnologia de informação para informatizar processos relacionados à gestão do negócio (sistemas $E R P$ ) e também aos fluxos de trabalho e interação com clientes. Um dos entrevistados ressaltou as vantagens do uso de sistemas de $C R M$ para registro de dados dos clientes e uso em campanhas, por exemplo. Outro entrevistado falou sobre o uso de sistemas que direcionam o fluxo de trabalho e automatizam processos (no caso dele em processos de auditoria, para checagem e cruzamento de dados). Como citado no item anterior, esta iniciativa na empresa DHoffmann Consultoria visa organizar o fluxo de trabalho e interação com clientes, com automação e registro das rotinas. Um sistema já foi avaliado e 
permite desenhar fluxos de trabalho, registrar atendimentos a clientes e a interação com eles (os clientes entram no sistema, realizam upload de arquivos, download de arquivos, abrem chamados, assistem a vídeos com conteúdo, entre outros), visando, inclusive, padronizar os processos de trabalho. Esta iniciativa é importante não apenas para aumento de produtividade nas atividades atuais como também para suportar novos serviços com alto grau de padronização (seja em consultorias ou em treinamentos);

k) Definição clara e formal dos papéis e responsabilidades entre todos os recursos humanos empresariais (relaciona-se com o impulsionador 5.1): a falta de clareza nestas definições é prejudicial ao negócio. Esta iniciativa visa combater o limitador de crescimento "superalocação do sócio consultor na execução", através do impulsionador mapeado nas entrevistas "delimitar atividades operacionais e estratégicas". Atualmente o pesquisador (consultor) exerce atividades operacionais (como recursos de projetos) e também estratégicas (como sócio). Com esta importante iniciativa, espera-se delimitar as atividades que ficarão sob sua responsabilidade, sob responsabilidade de sua sócia (esposa) e dos outros colaboradores contratados. Espera-se delimitar muito bem as atividades relacionadas à execução de projetos, liderança e suporte aos projetos, linha de frente comercial, BackOffice comercial, administrativas e financeiras. Com isto otimizar o tempo dos recursos envolvidos, principalmente no uso eficiente de todos. Relaciona-se também com a iniciativa $\mathrm{B}$;

1) Incluir nas reuniões com equipe momento inovação e associar a plano operacional e tático (relaciona-se com o impulsionador 6.1, 6.2 e 6.3): um grande limitador ao crescimento evidenciado anteriormente é a limitação da inovação em produtos e processos. Os entrevistados enfatizaram muito a importância de ter um aprendizado rápido em projetos, um processo para obter ideias dos próprios colaboradores e ser pioneiro em novos serviços. Nos projetos atuais da DHoffmann são verificadas melhorias, algumas até introduzidas aos métodos próprios. Porém, isto não é realizado de forma estruturada e sistematizada, perdendo eficiência em si no sentido de não se tornar aplicável aos processos. A iniciativa visa incluir nas reuniões com a equipe um momento para discutir tais melhorias, além de oportunidades de mercado observadas. Deve-se incluir em um 
plano a implantação destas ações, assim como a sua adição aos processos internos e aos métodos de consultoria. Dar agilidade a este processo pode propiciar a oportunidade de ser pioneiro em alguns tipos de serviço e obter retornos financeiros associados ao pioneirismo;

m) Desenho do novo funil de vendas envolvendo conteúdo - palestras e cursos - e programas de relacionamento com decisores - grupos de negócio, associações gerais e setoriais (relaciona-se com o impulsionador 7.1 e 9.1): esta iniciativa está traçada para suplantar a limitação da "falta de comunicação assertiva da marca com o mercado". Um fato apontado nas entrevistas é que não se pode contar apenas com indicações passivas de negócio, apesar de serem as mais legítimas e que se tornam demonstração de que o resultado do trabalho é positivo na percepção dos clientes. A DHoffmann Consultoria, como apontado no relato da experiência, hoje se encontra em uma postura passiva em relação à comunicação de sua própria marca com o mercado. Os entrevistados citaram ações de comunicação da marca com o mercado e não apenas a de enfatizar o nome do próprio consultor, mas sim trabalhar com ações planejadas e coerentes com os objetivos organizacionais. Os exemplos são de uso de mídias sociais de forma planejada, participação de associações para fomento de conteúdo e relacionamento (tais como associações comerciais regionais, câmaras de comércio, grupos de networking) e geração de conteúdo qualificado para se posicionar como formador de opinião (fornecimento de palestras, entrevistas e cursos). O pesquisador já realizou algumas destas iniciativas de forma isolada (participação de grupos de networking e associação comercial, publicações em mídias sociais, geração de conteúdo de várias naturezas), porém não de forma planejada. Esta iniciativa visa a criação de um plano de comunicação da marca visando resultado comercial, ou seja, geração de oportunidades reais de negócio para crescimento dos projetos de consultoria e assessoria, além dos cursos livres. Isto deve ser implementado e monitorado com uma análise do custo-benefício da implantação, ou seja, novas vendas versus investimento financeiro realizado nas ações;

n) Formalizar Método de Trabalho incluindo materiais tangíveis nos principais pontos de contatos de um projeto ou assessoria (relaciona-se com o impulsionador 7.2): alguns dos 
entrevistados citaram como fator impulsionador de crescimento a ação de tornar tangível o serviço prestado e resultado alcançado, isto pautado na transparência em todos os pontos de contato com os clientes. Tratando-se de prestadores de serviço, a tangibilização é um dos atributos necessários e faz parte do composto de marketing essencial ao posicionamento de uma marca. Esta iniciativa visa não apenas documentar o método de trabalho mas também repensar o método incluindo nos pontos de contato com o cliente (seja um primeiro contato, uma proposta, uma reunião realizada, uma reunião de entrega, um material dentro de uma reunião de acompanhamento ou em contatos pós-venda) atributos de comunicação em que ele possa tangibilizar o resultado e os valores essenciais da consultoria e assessoria. Com isto espera-se retirar qualquer ruído de entrega (pois muitas vezes o resultado financeiro não é direto pois depende do próprio cliente implantar algumas ações);

o) Separação entre ambiente residencial e escritório de trabalho (relaciona-se com o impulsionador 8.1): esta iniciativa tem como objetivo suplantar a limitação ao crescimento de "não ter estrutura física adequada". Foi unânime entre os entrevistados a importância de separar ambiente físico residencial e profissional se, de fato, o profissional deseja crescer como organização (não trabalhando mais sozinho de forma autônoma). Ao iniciar a pesquisa, o pesquisador tinha um escritório de trabalho dentro de sua residência, ou seja, denotando ser uma microempresa no livre conceito aplicado a esta pesquisa. Apesar de ser um ambiente grande (com sala de trabalho e sala de reunião para cliente) não transparecia o profissionalismo que deveria transparecer. Segundo os entrevistados, o ambiente profissional segregado e organizado transmite uma imagem positiva de organização, seriedade e profissionalismo. Durante o período desta pesquisa, a DHoffmann Consultoria migrou para um escritório próprio contendo espaço para seus colaboradores e para recepcionar seus clientes em um ambiente agradável, contendo sala específica de reunião. O ambiente comportou os novos colaboradores e foi usado inúmeras vezes para receber clientes (para reuniões) e potenciais clientes (para reuniões iniciais de prospecção ou apresentação de propostas). O resultado observado é que, com o espaço físico próprio, criou-se um ambiente que permeia os valores essenciais da empresa, mais produtivo (pois não se confunde com o ambiente residencial), mais 
disciplinado (horário de trabalho consigo mesmo e dos colaboradores), e que transmite uma imagem positiva e profissional (recebemos e fechamos negócios efetivamente neste novo ambiente). Portanto, esta iniciativa foi implantada e bem-sucedida. Denota também a migração de micro para pequena empresa pela DHoffmann Consultoria, conforme o livre conceito aplicado nesta pesquisa;

p) Remodelagem dos parceiros estratégicos para oferta casada (relaciona-se com o impulsionador 9.3): esta iniciativa está desenhada para combater a limitação de "não aproveitar todas as oportunidades comerciais". Dentro dos entrevistados, sendo prestadores de serviço, uma prática comum observada foi o uso de parceiros estratégicos comerciais para alavancar novos negócios. Estes parceiros podem ser especialistas complementares ao portfólio da empresa ou até realizar os mesmos serviços para apoio em momento de superlotação da capacidade de produção. A maior parte dos entrevistados utilizam parceiros como indicadores de negócios também. Porém esta prática deve ser planejada e estar de acordo com os objetivos organizacionais. Não se pode correr o risco de estabelecer parcerias para ofertar negócios fora da missão empresarial, por exemplo. A DHoffmann Consultoria estabeleceu, ao longo do tempo, parceiros de negócios em áreas correlatas, tais como: pesquisa de mercado, serviços jurídicos, serviços contábeis, serviços publicitários e de marketing e serviços voltados a recursos humanos. Porém, isso não foi feito de forma organizada. Esta iniciativa deve fazer com que a DHoffmann Consultoria repense os seus parceiros dentro do seu objetivo como organização. Quais parceiros são realmente complementares em seu portfólio e de confiança para serem ofertados oficialmente em seu portfólio? Quais parceiros podem ser bons indicadores de negócio? Quais parceiros podem ser utilizados em momentos de ultrapassagem de sua capacidade produtiva? Quais parceiros não agregam valor à sua oferta e devem ser retirados do portfólio? A grande rede de contato do pesquisador permitirá responder a estas questões e apoiar na reorganização da rede oficial de parceiros da empresa. Esta deverá estar orientada com os objetivos organizacionais e deve ser monitorada com métricas claras de resultado; 
q) Reflexão sobre o público-alvo dentro do plano estratégico empresarial (relaciona-se com o impulsionador 9.4): um bom exemplo citado por um dos entrevistados foi o de estabelecer uma estratégia específica para buscar grandes contratos. Obviamente que, antes de estabelecer a estratégia, ele definiu qual seria o público-alvo desta estratégia, no caso deles, os grandes contratos. A DHoffmann Consultoria sempre se posicionou para atender as pequenas e médias empresas (PMEs), mas, ao longo de seus atendimentos, também atendeu a microempresas, e, por observação, notou diferenças nesses públicos. As micro e pequenas empresas normalmente são mais sensíveis a preço e nunca contrataram um serviço de consultoria e assessoria empresarial como a ofertada. Além disso, observa-se que há um padrão em relação à demanda, ou seja, poderia ser ofertado um serviço mais padronizado, menos customizado. A equipe DHoffmann está trabalhando neste assunto já durante o período desta pesquisa, porém ainda sem produto final. As empresas em crescimento, seja pequena ou média, já possuem necessidades específicas e que demandam uma customização para atendimento. Este é o modo que a DHoffmann Consultoria atende atualmente. Esta iniciativa visa incluir nas reuniões esta reflexão estratégica: quem é o público-alvo da empresa? E quais os serviços que devem ser ofertados a cada um? Com isto se desdobrarão algumas outras iniciativas de adaptações de serviços e de comunicação, com reposicionamento da marca e novos objetivos comerciais de crescimento.

Este conjunto apresentado detalhadamente nos últimos parágrafos é denominado plano de intervenção e está relacionado na Figura 25: 
Figura 25 - Lista de Iniciativas participantes do plano de intervenção

\begin{tabular}{|l|}
\hline \multicolumn{1}{|c|}{ Intervenção (Iniciativas) } \\
\hline A- Substituição de recursos sem experiência por recurso sênior e com competência associada a vaga \\
\hline $\begin{array}{l}\text { B- Uso de consultoria especializada para prover líderes com ferramentas motivacionais associadas a clima e no } \\
\text { desenvolvimento pessoal da equipe associando-a a estratégia }\end{array}$ \\
\hline C- Uso de reunião mensal para discussão estratégica \\
\hline D- Desenho de remuneração variável \\
\hline E- Programa de Incentivo a Educação com uso de bolsa de ensino \\
\hline F- Formação do recurso familar para absorver atividades gerenciais \\
\hline G- Primeiro mapeamento para processos operacionais básicos \\
\hline H- Formação do Manual de Políticas e Processos da Empresa \\
\hline I- ERP básico para processo financeiro \\
\hline J- Implantação de sistema para controle de fluxos de trabalho e interação com clientes \\
\hline K- Definição clara e formal dos papéis e responsabilidades entre todos os recursos humanos empresariais \\
\hline L- Incluir nas reuniões com equipe momento inovação e associar a plano operacional e tático \\
\hline M- Desenho novo funil de vendas envolvendo conteúdo (palestras e cursos) e programas de relacionamento com decisores \\
(grupos de negócio, associações gerais e setoriais) \\
\hline N- Formalizar Método de Trabalho incluindo materiais tangíveis nos principais pontos de contatos de um projeto ou assessoria \\
\hline O- Separação entre ambiente residencial e escritório de trabalho. \\
\hline P- Remodelagem dos parceiros estratégicos para oferta casada \\
\hline Q- Reflexão sobre o público-alvo dentro do plano estratégico empresarial \\
\hline
\end{tabular}

Fonte: Autoria própria (2018).

Estas iniciativas estão relacionadas aos impulsionadores de crescimento já listados e, consequentemente, aos limitadores também já listados. O quadro abaixo (Fig. 26) demonstra o relacionamento entre as iniciativas e os impulsionadores. Quando há repetição da iniciativa é um indicativo de que uma iniciativa será usada como ação para vários impulsionadores ou para combater diversos limitadores. Observa-se também que o único impulsionador sem iniciativa vinculada é o de número 1 "Alinhamento anterior a composição da sociedade", pois a DHoffmann trata-se de uma sociedade já estabelecida em que o sócio majoritário é o pesquisador e o minoritário sua esposa. Não faria sentido estabelecer uma iniciativa de alinhamento de perfil de sócios anteriormente à composição da sociedade em uma sociedade já constituída. 
Figura 26 - Matriz relacionando impulsionadores e iniciativas

\begin{tabular}{|c|c|c|}
\hline $\begin{array}{c}\text { Limitadores do Crescimento (originados na } \\
\text { teoria e entrevistas) }\end{array}$ & $\begin{array}{l}\text { Impulsionadores do Crescimento (originados nas } \\
\text { entrevistas) }\end{array}$ & Intervenção (Iniciativas) \\
\hline $\begin{array}{l}\text { 1- O perfil e objetivos entre sócios não estão } \\
\text { alinhados com as necessidades organizacionais }\end{array}$ & 1.1 - Alinhamento anterior a composição da sociedade & \\
\hline \multirow{8}{*}{$\begin{array}{l}\text { 2- O perfil e objetivos da equipe não estão } \\
\text { alinhados com as necessidades organizacionais }\end{array}$} & 2.1 - Ter equipe com competências necessárias & $\begin{array}{l}\text { A- Substituição de recursos sem experiência por } \\
\text { recurso sênior e com competência associada a vaga }\end{array}$ \\
\hline & $\begin{array}{l}\text { 2.2 - Cumprir com os combinados, prover bom } \\
\text { ambiente e ferramentas de trabalho }\end{array}$ & $\begin{array}{l}\text { B- Uso de consultoria especializada para prover líderes } \\
\text { com ferramentas motivacionais associadas a clima e } \\
\text { no desenvolvimento pessoal da equipe associando-a a } \\
\text { estratégia }\end{array}$ \\
\hline & 2.3 - Uso da liderança como exemplo & $\begin{array}{l}\text { B- Uso de consultoria especializada para prover líderes } \\
\text { com ferramentas motivacionais associadas a clima e } \\
\text { no desenvolvimento pessoal da equipe associando-a a } \\
\text { estratégia }\end{array}$ \\
\hline & 2.4 - Uso correto da comunicação com colaboradores & C- Uso de reunião mensal para discussão estratégica \\
\hline & $\begin{array}{l}\text { 2.5 - Retenção através de remuneração variável e } \\
\text { programa de inclusão como sócio (Driver } \\
\text { meritocracia) }\end{array}$ & D- Desenho de remuneração variável \\
\hline & \begin{tabular}{|l|} 
2.6 - Ter boa gestão do conhecimento (administração \\
do capital intelectual)
\end{tabular} & $\begin{array}{l}\text { E- Programa de Incentivo a Educação com uso de } \\
\text { bolsa de ensino }\end{array}$ \\
\hline & 2.7 - Ter estratégia de desenvolvimento de pessoas & $\begin{array}{l}\text { B- Uso de consultoria especializada para prover líderes } \\
\text { com ferramentas motivacionais associadas a clima e } \\
\text { no desenvolvimento pessoal da equipe associando-a a } \\
\text { estratégia }\end{array}$ \\
\hline & 2.8 - Formação e uso de um gestor & $\begin{array}{l}\text { F- Formação do recurso familar para absorver } \\
\text { atividades gerenciais }\end{array}$ \\
\hline \multirow{2}{*}{$\begin{array}{l}\text { 3- Os processos não são padronizados e alinhados } \\
\text { com os objetivos organizacionais }\end{array}$} & \multirow{2}{*}{$\begin{array}{l}\text { 3.1 - Mapeamento e formalização de processos em } \\
\text { manuais }\end{array}$} & $\begin{array}{l}\text { G- Primeiro mapeamento para processos operacionais } \\
\text { básicos }\end{array}$ \\
\hline & & $\begin{array}{l}\text { H- Formação do Manual de Políticas e Processos da } \\
\text { Empresa }\end{array}$ \\
\hline \multirow{2}{*}{$\begin{array}{l}\text { 4- Falta de ferramenta tecnológica adequada para } \\
\text { suprir processos e ganho de produtividade }\end{array}$} & \multirow[b]{2}{*}{ 4.1 - Uso de ferramentas tecnológicas } & I- ERP básico para processo financeiro \\
\hline & & $\begin{array}{l}\text { J- Implantação de sistema para controle de fluxos de } \\
\text { trabalho e interação com clientes }\end{array}$ \\
\hline \multirow[b]{2}{*}{ 5- Superalocação do sócio-consultor na execução } & 5.1 - Delimitar atividades operacionais e estratégicas & $\begin{array}{l}\text { K- Definição clara e formal dos papéis e } \\
\text { responsabilidades entre todos os recursos humanos } \\
\text { empresariais }\end{array}$ \\
\hline & 5.2 - Disposição em delegar atividades (pelos sócios) & $\begin{array}{l}\text { B- Uso de consultoria especializada para prover líderes } \\
\text { com ferramentas motivacionais associadas a clima e } \\
\text { no desenvolvimento pessoal da equipe associando-a a } \\
\text { estratégia }\end{array}$ \\
\hline \multirow{3}{*}{$\begin{array}{l}\text { 6- Limitação da inovação em produtos e } \\
\text { processos }\end{array}$} & 6.1 - Uso de aprendizado rápido em projetos & $\begin{array}{l}\text { L- Incluir nas reuniões com equipe momento inovação } \\
\text { e associar a plano operacional e tático }\end{array}$ \\
\hline & $\begin{array}{l}\text { 6.2 - Processo para obter ideias dos próprios } \\
\text { colaboradores }\end{array}$ & $\begin{array}{l}\text { L- Incluir nas reuniões com equipe momento inovação } \\
\text { e associar a plano operacional e tático }\end{array}$ \\
\hline & 6.3 - Ser pioneiro é importante & $\begin{array}{l}\text { L- Incluir nas reuniões com equipe momento inovação } \\
\text { e associar a plano operacional e tático }\end{array}$ \\
\hline \multirow{2}{*}{$\begin{array}{l}\text { 7- Falta de comunicação assertiva da marca com } \\
\text { o mercado }\end{array}$} & 7.1 - Uso da rede de contatos de forma estratégica & $\begin{array}{l}\text { M- Desenho novo funil de vendas envolvendo } \\
\text { conteúdo (palestras e cursos) e programas de } \\
\text { relacionamento com decisores (grupos de negócio, } \\
\text { associações gerais e setoriais) }\end{array}$ \\
\hline & 7.2 - Tangilizar resultados para clientes & $\begin{array}{l}\text { N- Formalizar Método de Trabalho incluindo materiais } \\
\text { tangíveis nos principais pontos de contatos de um } \\
\text { projeto ou assessoria }\end{array}$ \\
\hline 8- Não ter estrutura física adequada & 8.1 - Adequação da estrutura física & $\begin{array}{l}\text { O- Separação entre ambiente residencial e escritório } \\
\text { de trabalho. }\end{array}$ \\
\hline \multirow{4}{*}{$\begin{array}{l}\text { 9- Não aproveitar todas as oportunidades } \\
\text { comerciais }\end{array}$} & 9.1 - Uso intensivo de venda cruzada & $\begin{array}{l}\text { M- Desenho novo funil de vendas envolvendo } \\
\text { conteúdo (palestras e cursos) e programas de } \\
\text { relacionamento com decisores (grupos de negócio, } \\
\text { associações gerais e setoriais) }\end{array}$ \\
\hline & $\begin{array}{l}9.2 \text { - Uso de processos e ferramenta de CRM para } \\
\text { retenção das informações }\end{array}$ & $\begin{array}{l}\text { J- Implantação de sistema para controle de fluxos de } \\
\text { trabalho e interação com clientes }\end{array}$ \\
\hline & 9.3 - Uso estratégico de parceiros comerciais & $\begin{array}{l}\text { P- Remodelagem dos parceiros estratégicos para } \\
\text { oferta casada }\end{array}$ \\
\hline & 9.4 - Estratégia para acessar maiores contratos & $\begin{array}{l}\text { Q- Reflexão sobre o público-alvo dentro do plano } \\
\text { estratégico empresarial }\end{array}$ \\
\hline
\end{tabular}

Fonte: Autoria própria (2018). 
Como citado anteriormente, durante o processo de pesquisa o pesquisador pode implantar, totalmente ou parcialmente, cinco das dezessete intervenções mapeadas no plano de intervenção, dentro do método de pesquisa-ação, observando resultados práticos das implantações ocorridas.

Os resultados específicos qualitativos de cada ação já foram citados nos tópicos anteriores. É necessário a esta pesquisa a tentativa de expressar quantitativamente o resultado de cada iniciativa, porém é extremamente difícil fazê-lo dado a natureza de cada uma delas. Entendendo que o conjunto destas iniciativas propiciou determinado resultado, a forma encontrada para expressar como resultado final, ou seja, do conjunto delas é a variação do valor do faturamento médio mensal em um período antes e depois do início do processo desta pesquisa do mestrado profissional. Foi levantado o valor médio de faturamento mensal do período anterior ao início desta pesquisa, período entre maio de 2013 e dezembro de 2015, este valor foi explicitado como 100 (base 100). Foi levantado o valor médio de faturamento mensal do ano de 2016 (janeiro a dezembro), 2017 (de janeiro a dezembro), de 2018 (de janeiro a julho) e o que foi denominado de "depois", ou seja, período posterior ao início do mestrado (janeiro de 2016 a julho de 2018). Conforme gráfico apresentado a seguir, observa-se que todos os períodos posteriores ao início da pesquisa apresentaram um crescimento em relação ao período denominado "antes" e de forma consistente, ou seja, um crescimento período após período. O crescimento entre o ano de 2016 e o período "antes" foi de $68,4 \%$. O crescimento entre o ano de 2017 e o período "antes" foi de 101,5\%. O crescimento entre o ano de 2018 e o período "antes" foi de $152,4 \%$. O crescimento do período "depois" e período "antes" foi de 100,2\%, ou seja, o faturamento médio mensal dobrou no período "depois" do início da pesquisa. Observa-se também que o crescimento anual existiu, 2017 cresceu frente a 2016 e 2018 cresceu frente a 2017.

Este crescimento em faturamento obviamente não foi devido apenas a estas cinco iniciativas implantadas porque a empresa ficou exposta a diversas variáveis no período. Mas pode-se afirmar que há grande correlação positiva entre a implantação e o crescimento em faturamento, constatando-se o resultado positivo até o momento e encorajando para implantação das demais iniciativas. Observa-se também que este crescimento foi verificado em um período de grande contração econômica brasileira.

Na Figura 27 segue gráfico que demonstra a evolução do faturamento médio mensal: 
Figura 27 - Evolução do Faturamento Médio Mensal DHoffmann Consultoria

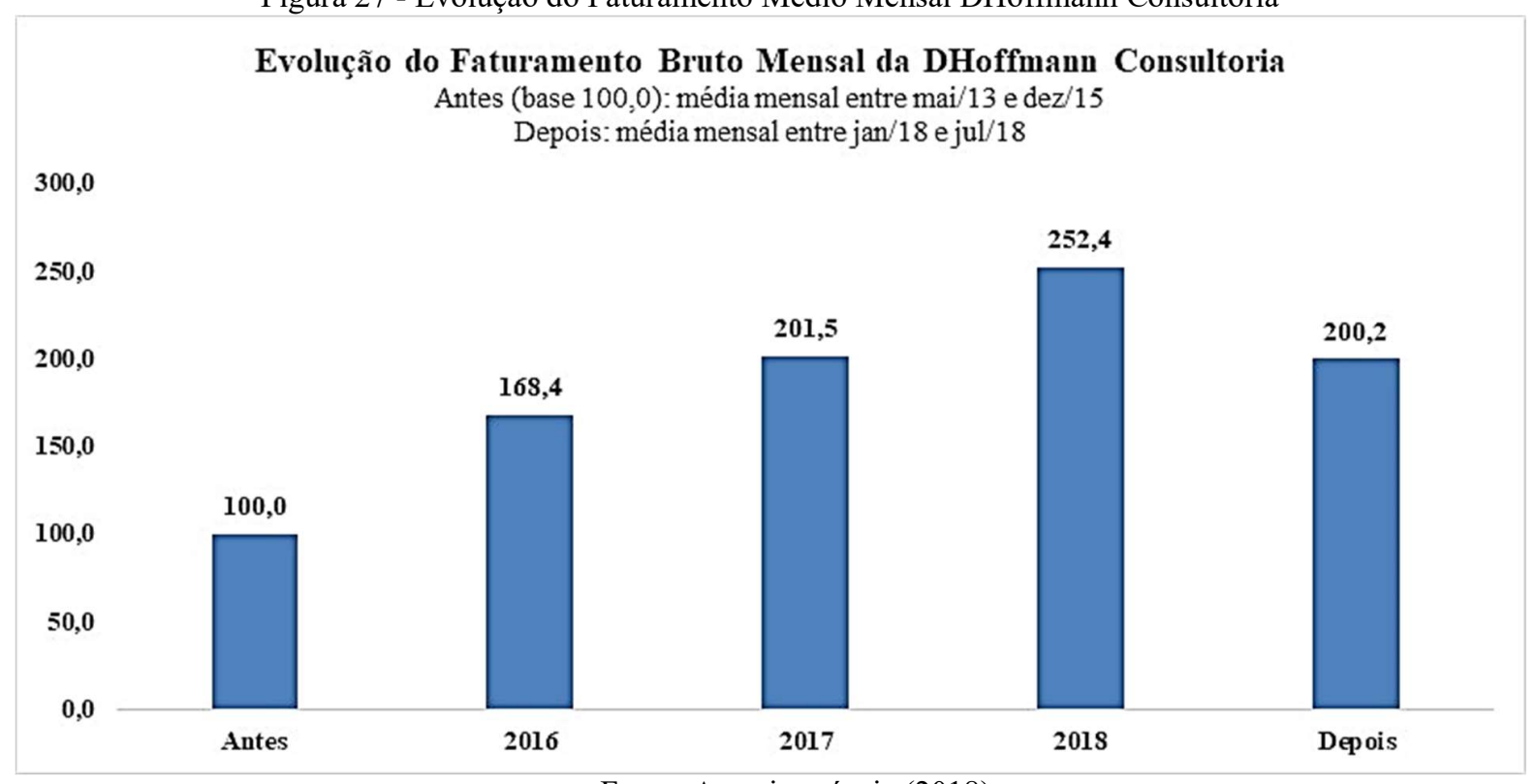

Fonte: Autoria própria (2018).

Abaixo (Fig. 28) é apresentado quadro-resumo das iniciativas ou intervenções já realizadas, totalmente ou parcialmente, na DHoffmann Consultoria.

Figura 28 - Lista de intervenções já realizadas

\begin{tabular}{|l|}
\hline \multicolumn{1}{|c|}{ Intervenção Realizada (Iniciativas) } \\
\hline A- Substituição de recursos sem experiência por recurso sênior e com competência associada a vaga \\
\hline C- Uso de reunião mensal para discussão estratégica \\
\hline G- Primeiro mapeamento para processos operacionais básicos \\
\hline I- ERP básico para processo financeiro \\
\hline O- Separação entre ambiente residencial e escritório de trabalho. \\
\hline
\end{tabular}
Fonte: Autoria própria (2018).

O quadro-resumo seguinte (Fig. 29) refere-se à matriz que demonstra a relação entre os limitadores de crescimento e impulsionadores de crescimento mapeados na teoria e nas entrevistas realizadas, assim como os exemplos práticos explicitados pelos entrevistados, com as intervenções realizadas e a realizar, que visam suplantar as limitações e possibilitar o crescimento da consultoria e assessoria empresarial. Atendendo, assim, ao objetivo secundário de "elaborar uma sistematização das iniciativas que irão suplantar as limitações identificadas e possibilitarão o crescimento da consultoria e assessoria empresarial para validação posterior”. 
Figura 29 - Matriz Geral de Relação Limitadores, Impulsionadores e Intervenções

\begin{tabular}{|c|c|c|c|c|}
\hline $\begin{array}{l}\text { Limitadores do Crescimento (originados na teoria e } \\
\text { entrevistas) }\end{array}$ & $\begin{array}{l}\text { Impulsionadores do Crescimento (originados nas } \\
\text { entrevistas) }\end{array}$ & Intervenção Realizada (Iniciativas) & Intervenção a Realizar (Iniciativas) & Exemplos práticos citados nas entrevistas (Iniciativas) \\
\hline $\begin{array}{l}\text { 1- } 0 \text { perfil e objetivos entre sócios não estão alinhados } \\
\text { com as necessidades organizacionais }\end{array}$ & 1.1 - Alinhamento anterior a composição da sociedade & & & $\begin{array}{l}\text { É observado isso antes de compor o quadro societárí (perfili: ser multifínção, formação acadêmica } \\
\text { em ciências contábeis, ter habilidade em gestão de pessoas). }\end{array}$ \\
\hline \multirow{8}{*}{$\begin{array}{l}\text { 2- } 0 \text { perfil e objetivos da equipe não estão alinhados } \\
\text { com as necessidades organizacionais }\end{array}$} & 2.1- Ter equipe com competências necessárias & $\begin{array}{l}\text { A- Substituiç̃ão de recursos sem experiência por } \\
\text { recurso sênior e com competência associada a vaga }\end{array}$ & & $\begin{array}{l}\text { Ajuste no processo de recrutamento e seleção com apoio de terceiro capacitado. Vagas em } \\
\text { Universidades com chamada de Trainee }\end{array}$ \\
\hline & $\begin{array}{l}\text { 2.2- Cumprir com os combinados, prover bom } \\
\text { ambiente e ferramentas de trabalho }\end{array}$ & & $\begin{array}{l}\begin{array}{l}\text { B- Uso de consultoria especializada para prover lideres } \\
\text { com ferramentas motivacionais associadas a clima e } \\
\text { no desenvvolvimento pessoal da equipe associando-a a } \\
\text { estratégia }\end{array} \\
\end{array}$ & $\begin{array}{l}\text { Flexibilidade funcionários trabalhar fora, sistema forte, pgto hora extra, beneficicos adequados. } \\
\text { Estratégias de bom clima organizacional (ambiente familiar) }\end{array}$ \\
\hline & 2.3 - Uso da liderança como exemplo & & $\begin{array}{l}\begin{array}{l}\text { B- Uso de consultoria especializada para prover lideres } \\
\text { com ferramentas motivacionais associadas a clima e } \\
\text { no desenvvolvimento pessoal da equipe associando-a a } \\
\text { estratégia }\end{array} \\
\end{array}$ & \\
\hline & 2.4 - Uso correto da comunicação com colaboradores & c. Uso de reunião mensal para discussão estratégica & & $\begin{array}{l}\text { Reuniäo semanal, uso de avaliaçãa de desempenho, convenção anual (planejamento estratégico } \\
\text { compartilhado e comunicados entre todos) }\end{array}$ \\
\hline & $\begin{array}{l}2.5 \text { - Retenção através de remuneração varíável e } \\
\text { programa de inclusão como sócio (Driver } \\
\text { meritocracia) }\end{array}$ & & D- Desenho de remuneraçăo variável & 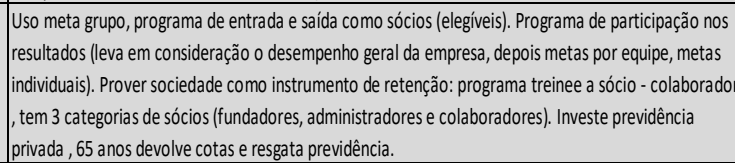 \\
\hline & $\begin{array}{l}\text { 2.6- Ter boa gestão do conhecimento (administrtraçao } \\
\text { do capital intelectual) }\end{array}$ & & $\begin{array}{l}\text { E- Programa de Incentivo a Educação com uso de } \\
\text { bolsa de ensino }\end{array}$ & Programa de educação continuada, pagamento de plataformas de conhecimento \\
\hline & 2.7 - Ter estratégia de desenvolvimento de pessoas & & $\begin{array}{l}\text { B- Uso de consultoria especializada para prover lideres } \\
\text { com ferramentas motivacionais associadas a clima e } \\
\text { no desenvvolvimento pessoal da equipe associando-a a } \\
\text { estratégia }\end{array}$ & $\begin{array}{l}\text { Programa formal de desenvolvimento individual ( (POI), feedback liderese colaboradores- } \\
\text { formalizado. identidade empresarial e valorização das pessoas. identificar potenciais, envolver } \\
\text { potenciais lideres em decisōes, coaching }\end{array}$ \\
\hline & 2.8 - Formaç̃o e uso de um gestor & & $\begin{array}{l}\text { F- Formação do recurso familar para absorver } \\
\text { atividades gerenciais }\end{array}$ & $\begin{array}{l}\text { Instrumentos usados para sócio sair da operação: em } 2013 \text { trouxe um gestor para dentro da } \\
\text { organização (introduzii politicas e processos. Nasceu uma governança). } 0 \text { gatilho foi não enxergar } \\
\text { onde estava o problema financeiro. Instituiu governança corporativa. Politicas em geral. Equipe: um } \\
\text { bom gestor é fundamental para o crescimento. É o fator primordalal. }\end{array}$ \\
\hline $\begin{array}{l}\text { 3- Os processos não são padronizados e alinhados com } \\
\text { os objetivos organizacionais }\end{array}$ & $\begin{array}{l}\text { 3.1- Mapeamento e formalização de processos em } \\
\text { manuais }\end{array}$ & $\begin{array}{l}\text { G-Primeiro mapeamento para processos operacionais } \\
\text { básicos }\end{array}$ & $\begin{array}{l}\text { H- Formação do Manual de Politicas e Processos da } \\
\text { Empresa }\end{array}$ & Uso de terceiros para apoio. Implantação de formulários e criação de rotinas \\
\hline $\begin{array}{l}\text { 4- Falta de ferramenta tecnológica adequada para } \\
\text { suprir processos e ganho de produtividade }\end{array}$ & 4.1 - Uso de ferramentas tecnológicas & 1- ERP básico para processo financeiro & $\begin{array}{l}\text { J- Implantação de sistema para controle de fluxos de } \\
\text { trabalho e interaçẫo com clientes }\end{array}$ & 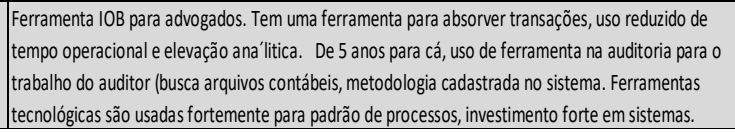 \\
\hline
\end{tabular}

Fonte: Autoria própria (2018). 
Figura 30 - Matriz Geral de Relação Limitadores, Impulsionadores e Intervenções

\begin{tabular}{|c|c|c|c|c|}
\hline $\begin{array}{c}\text { Limitadores do Crescimento (originados na teoria e } \\
\text { entrevistas) }\end{array}$ & $\begin{array}{c}\text { Impulsionadores do Crescimento (originados nas } \\
\text { entrevistas) }\end{array}$ & Intervenção Realizada (Iniciativas) & Intervenção a Realizar (Iniciativas) & Exemplos práticos citados nas entrevistas (Iniciativas) \\
\hline \multirow[b]{2}{*}{ 5- Superalocação do sócio-consultor na execução } & 5.1 - Delimitar atividades operacionais e estratégicas & & $\begin{array}{l}\text { K- Definição clara e formal dos papéis e } \\
\text { responsabilidades entre todos os recursos humanos } \\
\text { empresariais }\end{array}$ & \\
\hline & 5.2- Disposição em delegar atividades (pelos sócios) & & $\begin{array}{l}\text { B- Uso de consultoria especializada para prover líderes } \\
\text { com ferramentas motivacionais associadas a clima e } \\
\text { no desenvolvimento pessoal da equipe associando-a a } \\
\text { estratégia }\end{array}$ & \\
\hline \multirow{3}{*}{ 6- Limitação da inovação em produtos e processos } & 6.1 - Uso de aprendizado rápido em projetos & & $\begin{array}{l}\text { L- Incluir nas reuniöes com equipe momento inovação } \\
\text { e associar a plano operacionale tático }\end{array}$ & Consultor traz para dentro da organização idelias e as implementa, realizando testes rápidos \\
\hline & $\begin{array}{l}\text { 6.2- Processo para obter ideias dos próprios } \\
\text { colaboradores }\end{array}$ & & $\begin{array}{l}\text { L- Incluir nas reuniöe com equipe momento inovação } \\
\text { e associar a plano operacionale tático }\end{array}$ & $\begin{array}{l}\text { existe uma área comercial / marketing, reuniôes periódicas com sócios e lideres a fim de atualizar } \\
\text { produtos e entrada de novos (vem dos clientes e mudanças dalegislação). }\end{array}$ \\
\hline & 6.3- Ser pioneiro é importante & & $\begin{array}{l}\text { L- Incluir nas reuniöes com equipe momento inovação } \\
\text { e associar a plano operacional e tático }\end{array}$ & $\begin{array}{l}\text { Atenção ao mercado e alteraçōes. Ser pioneiro é muito importante. Estudiosos (12 professores e } 10 \\
\text { instrutoreses da IOB), estar na vanguarda. Antecipar as mudanças legais. }\end{array}$ \\
\hline \multirow{2}{*}{$\begin{array}{l}\text { 7. Falta de comunicação assertiva da marca com o } \\
\text { mercado }\end{array}$} & 7.1 - Uso da rede de contatos de forma estratégica & & $\begin{array}{l}\text { M- Desenho novo funil de vendas envolvendo } \\
\text { conteúdo (palestras e cursos) e programas de } \\
\text { relacionamento com decisores (rrupos de negócio, } \\
\text { associaçães gerais esetoriais) }\end{array}$ & \\
\hline & 7.2- Tangilizar r resultados para clientes & & $\begin{array}{l}\text { N- Formalizar Método de Trabalho incluindo materiais } \\
\text { tangiveis nos principais pontos de contatos de um } \\
\text { projeto ou assessoria }\end{array}$ & Uso da transparência na comunicacãa \\
\hline 8- Não ter estrutura física adequada & 8.1 - Adequação da estrutura física & $\begin{array}{l}\text { 0- Separação entre ambiente residencial e escritório } \\
\text { de trabalho. }\end{array}$ & & \\
\hline \multirow{4}{*}{ 9- Não aproveitar todas as oportunidades comerciais } & 9.1 - Uso intensivo de venda cruzada & & $\begin{array}{l}\text { M- Desenho novo funil de vendas envolvendo } \\
\text { conteúdo (palestras e cursos) e programas de } \\
\text { relacionamento com decisores (grupos de negócio, } \\
\text { associaçōes gerais e setoriais) }\end{array}$ & \\
\hline & $\begin{array}{l}\text { 9.2- Uso de processos e ferramenta de CRM para } \\
\text { retenção das informaçôes }\end{array}$ & & $\begin{array}{l}\text { J- Implantação de sistema para controle de fluxos de } \\
\text { trrabalho interąăâo com clientes }\end{array}$ & \\
\hline & 9.3- Uso estratégico de parceiros comerciais & & \begin{tabular}{|l|l|}
$\begin{array}{l}\text { P- Remodelagem dos parceiros estratégicos para } \\
\text { oferta casada }\end{array}$ & \\
\end{tabular} & \\
\hline & 9.4- Estratégia para acessar maiores contratos & & $\begin{array}{l}\text { Q- Reflexão sobre o público-alvo dentro do plano } \\
\text { estratégico empresarial }\end{array}$ & Parceria com grandes plataformas e certificadoras para credenciamento \\
\hline
\end{tabular}

Fonte: Autoria própria (2018) 


\section{CONSIDERAÇÕES FINAIS, LIMITAÇÕES E ESTUDOS FUTUROS}

Na percepção do pesquisador, o método de pesquisa profissional vivenciado ao longo deste trabalho dentro do programa de mestrado profissional da FEA-USP foi muito enriquecedor, para si próprio e para todos que poderão consultar este documento.

Um motivo apenas basta para torná-lo rico: a possibilidade de partir de um problema prático (e neste caso vivenciado pelo próprio autor em sua empresa) e tentar buscar alternativas para solucioná-lo, através dos achados teóricos e práticos. Além disto, o método empregado neste trabalho (o da pesquisa-ação) possibilitou testar a efetividade de algumas destas ações, com resultados práticos evidenciados. E não é isto que os administradores buscam no seu dia a dia? Buscam resolver problemas de origem prática.

A análise utilizando o método de triangulação, mesclando diversas fontes de informação, tais como problemática prática evidenciada, referências bibliográficas, achados nas entrevistas e observações práticas das intervenções realizadas até o momento de finalização desta dissertação, possibilitou o atendimento aos objetivos desta dissertação, de forma prática e com as limitações evidenciadas a seguir.

Uma das limitações constatadas para esta pesquisa foi a falta de tempo (por se tratar de um mestrado) de aplicar o plano de intervenção na íntegra e aplicar uma pesquisa quantitativa para validar este plano. Foram aplicadas cinco das dezessete iniciativas listadas.

A outra limitação existente nesta pesquisa foi o fato de ser de caráter qualitativo, ou seja, o conjunto de entrevistados representou a realidade de seis empresas, seis experiências. Estas podem não corresponder à realidade da totalidade das empresas com o mesmo perfil em uma abrangência nacional.

Segundo o Sebrae (2014), as micro e pequenas empresas são encerradas, ou seja, não crescem e morrem, por causa de falhas no planejamento prévio, deficiências na gestão empresarial e comportamento empreendedor inadequado. Pode-se presumir que as empresas que permanecem abertas e teoricamente obtêm sucesso são aquelas que utilizam boas práticas de gestão e que há um bom comportamento orientado ao empreendedorismo por parte do seu fundador, que pode ser gestor e técnico ao mesmo tempo. 
Outros elementos são necessários de serem adicionados a esta linha de raciocínio, as características ou particularidades das pequenas empresas, sendo as principais: recursos escassos (financeiros, humanos e tecnológicos), estrutura centralizada e não formalizada, gestão personalizada e dependente do proprietário-dirigente, a não utilização de instrumentos administrativos formais e a atuação técnica e administrativa dos proprietários (normalmente).

Estes elementos fizeram parte desta pesquisa na medida que foram evidenciados nas limitações de crescimento da organização pertencente ao pesquisador, a DHoffmann Consultoria. Dentro da problemática foram constatados como causas: recursos limitados, baixo nível de padronização e posicionamento sem clareza. É clara a correlação entre as características de pequenas empresas e as causas da limitação do crescimento organizacional. A DHoffmann Consultoria é uma microempresa que acabou de se tornar uma pequena empresa e está em crescimento. O objetivo desta pesquisa era identificar iniciativas para impulsionar este crescimento.

Estas iniciativas estão relacionadas às boas práticas de gestão e ao bom comportamento orientado ao empreendedorismo por parte de seu fundador. As intervenções já realizadas se relacionaram com a segmentação do problema de pesquisa evidenciado no diagrama de Ishikawa apresentado no capítulo 1: recursos limitados, posicionamento sem clareza e baixo nível de padronização. Da mesma forma as intervenções a serem realizadas estão amarradas a segmentação de problema evidenciada anteriormente.

Realizar as entrevistas com pessoas da rede de contato do pesquisador foi altamente enriquecedor, pois tratavam-se de casos reais de empresas que cresceram, porém nenhuma se tornou uma grande empresa. Porém, passaram de micro para pequenas e algumas a médias, suplantando as limitações de crescimento. Chegaram a crescer utilizando conhecimentos prévios, conhecimentos adquiridos ao longo da carreira ou foi um crescimento baseado na tentativa e erro. O importante é que cresceram, e os principais impulsionadores deste crescimento evidenciado foram citados nesta pesquisa. Pode-se notar que todos os impulsionadores ou se relacionam a boas práticas de gestão (como utilizar da forma mais eficiente possível os recursos disponíveis na empresa, mesmo se escassos) ou aos aspectos comportamentais (como lidar com a mudança no aspecto do empreendedorismo e com as pessoas). 
Como visto no capítulo dois, a fase de crescimento na pequena empresa se caracteriza pela existência de uma organização lucrativa, porém com necessidade de grandes investimentos em capital de giro e ainda uma estrutura mais formal para suportar tal crescimento. É necessário ter equilíbrio entre investimentos financeiros e controle operacional. A estrutura formal aqui evidenciada pode ser relacionada às boas práticas de gestão citadas.

Segundo estudo da consultoria Deloitte e da revista Exame (Deloitte; Exame,2016), as PMEs que cresceram possuíam alguns pilares centrais de suporte a este crescimento: continuidade dos investimentos (com foco em otimizar processos, obter ganho de produtividade e rever o portfólio de apostas estratégicas); busca por eficiência (foco no core business e revisão de processos); monitoramento de desempenho e mercado (acompanhamento constante de desempenho); governança corporativa (práticas de transparência); e foco na sustentabilidade do negócio (monitoramento do nível de endividamento empresarial). Destes impulsionadores citados, apenas o monitoramento do nível de endividamento empresarial não foi citado nas entrevistas. Apesar que, provavelmente, esse dado seja monitorado pelos empresários entrevistados.

O aspecto comportamental empreendedor não foi citado no estudo da consultoria Deloitte e da revista Exame, porém foi amplamente citado pelos entrevistados. O comportamento empreendedor, juntamente com a gestão de seu pessoal (para motivá-los), foi a citação número um dos entrevistados e unânime entre todos. Isto, inclusive, não era esperado pelo pesquisador. Retomando Gerber (2011), estudioso de pequenos negócios, o indivíduo que abre um negócio possui, ou deve possuir, três personalidades (ou capacidades), que podemos entender também como papéis ou funções distintas: empreendedora, administradora e a técnica. Entende-se, então, que o aspecto comportamental também citado pelos entrevistados parte de dentro para fora, ou seja, começa na forma como o empresário lida com a própria função e passa pela forma como ele gere seus recursos humanos. $\mathrm{O}$ pesquisador, em sua empresa, pode experimentar uma ação praticada que gerou um grande resultado. A inclusão de um colaborador com maior nível de experiência gerou ampliação de despesas, porém grande impacto positivo na organização. É o equilíbrio entre investimento financeiro e controle operacional citado como um grande desafio da fase de crescimento na 
pequena empresa. Mas, para isso, foi preciso alterar primeiramente a forma de olhar para o problema. Anteriormente ao fato, o pesquisador procurava gastar menos com recursos humanos sem experiência por causa da restrição de recursos financeiros. Agora, com esta nova postura, passou a gastar mais com recursos humanos com experiência visando a diminuição da restrição de recursos financeiros, ou seja, ampliar suas margens financeiras. O resultado aconteceu de fato.

Como contribuição desta pesquisa, espera-se que empresários, ou aspirantes a empresários, que passam por situações semelhantes às enfrentadas pelo pesquisador possam utilizar-se das evidências práticas deste material aplicando-o em suas próprias organizações e colhendo bons resultados. O Brasil necessita que as micro e pequenas empresas cresçam de forma sustentável, isto gera um alto impacto social e econômico ao país. Talvez haja uma contribuição à ciência da administração na medida que alguns impulsionadores coletados nas entrevistas não foram evidenciados na teoria pesquisada. Além disto, o resultado desta pesquisa fez com que o pesquisador pensasse em lançar um novo serviço para sua consultoria. Seria um treinamento voltado a outras empresas de setores correlatos sobre como identificar limitadores do crescimento e como contornar com as possibilidades de utilizarem impulsionadores já mapeados. Pode também virar um serviço de consultoria em processos de diagnóstico incorporando aos métodos próprios de trabalho. Ou seja, a pesquisa abriu horizontes também para novas fontes de receita para a empresa estudada.

Como estudos futuros, uma vertente de continuidade desta pesquisa é a aplicação do plano de intervenção na íntegra na DHoffmann Consultoria e a compilação de seus resultados, como resultado final da pesquisa-ação aplicada a uma empresa. Será que todos os impulsionadores gerariam os resultados esperados?

Outro estudo interessante seria a ampliação desta mesma temática ampliando o conjunto de entrevistados e estendendo a outros setores da economia (comércio, indústria e agronegócio). Acredita-se, também, é uma hipótese, que os limitadores e impulsionadores se diferenciam pelo setor econômico, por exemplo, alguns setores sofrem grande impacto da legislação vigente, algo não evidenciado nos prestadores de serviço pesquisados. Além disto, a realização de estudos de casos múltiplos envolvendo pequenas empresas seria de grande valia para a ciência de administração. 
Um desdobramento natural desta pesquisa seria realizar a aplicação de um instrumento de pesquisa quantitativa para checagem da aderência do plano de intervenção traçado.

Com os pontos anteriores destacados, pode-se observar que esta pesquisa e o programa de mestrado profissional em empreendedorismo da FEA-USP pôde contribuir com a ciência da administração, empresários em geral, a própria empresa do pesquisador e sua rede de contatos. Conclui-se, também, que a questão de pesquisa e os seus objetivos foram todos cumpridos restando apenas trabalhar no restante da aplicação do plano de intervenção e as observações do resultado deste plano em sua totalidade. 


\title{
REFERÊNCIAS BIBLIOGRÁFICAS
}

\author{
ALMEIDA, M. I. R; FERNANDES, P; FRANCESCONI, M. Manual para Desenvolvimento \\ de Pesquisa Profissional. São Paulo: Atlas, 2019.
}

BLOCK, P. Consultoria: O Desafio da Liberdade. São Paulo: Editora Pearson Makron Books, 2001.

CÊRA, K; ESCRIVÃO FILHO, E. Particularidades de gestão da pequena empresa: condicionantes ambientais, organizacionais e comportamentais do dirigente. In: EGEPE Encontro de Estudos sobre Empreendedorismo e Gestão de Pequenas Empresas. 3.edição, 2003, Brasília. p. 796-812.

CEZARINO, L.; CAMPOMAR, M. C. Micro e pequenas empresas: características estruturais e gerenciais. São Paulo: FEA-USP, 2003.

CHOUDARY, SANGEET. Platform Scale: How an emerging business model helps startups build large empires with minimum investment. Platform Thinking Labs: 2015.

CHURCHILL, N.; LEWIS, V. The Five Stages of Small Business Growth. Harvard Business Review, May 1983.

DELOITTE; EXAME. As PMEs que mais crescem no Brasil. São Paulo: Editora Abril, 2016.

DRUCKER, P. Inovação e espírito empreendedor (entrepreneurship): prática e princípios. 3 edição. São Paulo: Pioneira, 1987.

FILLION, J. Visions et relations: Clefs Du succès de l'entrepreneur. Montreal: Lês Éditions de l'Entrepreneur, 1991.

FLICK, U. Introdução à Pesquisa Qualitativa. Terceira Edição. Porto Alegre: Artmed, 2009.

FRANCESCONI, M. Centro de Serviços Compartilhados para Pequenas Empresas: avaliação de uma iniciativa empreendedora de prestação de serviços. São Paulo: FEA-USP, 2016.

GASSMANN, O; FRANKENBERGER, K; CSIK, M. The Business Model Navigator. United Kingdom: Financial Times, 2014.

GERBER, M. E-myth mastery: the seven essential disciplines for building a world class company. New York: Harper Business, 2005.

GERBER, M. O Mito do Empreendedor. São Paulo: Editora Fundamento Educacional, 2011.

GERSICK, K. E., LANSBERG, I., HAMPTON, M. De geração para geração: ciclos de vida das empresas familiares. 4. ed. São Paulo: Negócio Editora, 1997. 
GLASER, B.; STRAUSS, A. The discovery of grounded theory: strategies for qualitative research. New York: Aldine de Gruyter; 1967

HAIR, J.; BABIN, B.; MONEY, A.; SAMOUEL, P. Fundamentos de Métodos de Pesquisa em Administração. Porto Alegre: Bookman, 2005.

IPEA. Micro e Pequenas Empresas Mercado de Trabalho e Implicação para o Desenvolvimento. Rio de Janeiro: Ipea, 2012.

ISHIKAWA, K. Controle de Qualidade Total: à maneira japonesa. Rio de Janeiro: Campus, 1993.

KOLB, D. Experiential Learning: Experience as the Source of Learning and Development. New Jersey: Prentice Hall, 1984.

LEMES JUNIOR, A.; PISA, B. Administrando Micro e Pequenas Empresas. Rio de Janeiro: Elsevier, 2010.

LEWIN, K. Teoria de campo em ciência social. São Paulo: Pioneira, 1965.

LEWIN, K. Problemas de dinâmica de grupo. São Paulo: Cultrix, 1978.

LONGENECKER, J.; MOORE, C.; PETTY, J.; PALICH, L. Administração de Pequenas Empresas. São Paulo: Cengage Learning, 2013.

LOVELOCK, C.; WIRTZ, J. Marketing de Serviços: Pessoas, Tecnologia e Resultados. São Paulo: Editora Pearson, 2006.

KAPLAN, R. S.; NORTON, D. P. Having Trouble with Your Strategy? Then Map It. Harvard Business Review, September-October 2000.

KAPLAN, R. S.; NORTON, D. P. The strategy map: guide to aligning intangible assets. Strategy \& Leadership, 2004, pp. 10-17.

KOLB, D. A. Experiential learning: experience as the source of learning and development. New Jersey: Prentice Hall, 1984.

KRAKAUER, P.; SANTOS, S. A.; ALMEIDA, M. I. R. Teoria da Aprendizagem Experiencial no Ensino de Empreendedorismo: Um Estudo Exploratório. Regepe, 2016.

MARTINS, G. de A.; THEÓPHILO, C. R. Metodologia da Investigação Científica para Ciências Sociais Aplicadas. São Paulo: Editora Atlas, 2009.

OLIVEIRA, O.; MELHADO, S. Proposta de um Modelo de Gestão para Pequenas Empresas de Projeto de Edifícios. Revista Gestão \& Tecnologia de Projetos, v. 3, n. 2, 2008. Disponível $\mathrm{em}:<\mathrm{http}: / / \mathrm{www} . r e v i s t a s . u s p . b r / g e s t a o d e p r o j e t o s / a r t i c l e / v i e w / 50944>$. Acesso em: 21 maio 2017. 
OSTERWALDER, A; PIGNEUR, Y. Business Model Generation. Rio de Janeiro: Editora Alta Books, 2011.

OSTERWALDER, A.; PIGNEUR, Y.; BERNARDA, G.; SMITH, A.; PAPADAKOS, T. Value Proposition Design: How To Create Products And Services Customers Want. Hoboken: John Wiley \& Sons, 2014.

PETRY, L.; NASCIMENTO, A. Um Estudo Sobre o Modelo de Gestão e o Processo Sucessório em Empresas Familiares. Revista Contabilidade \& Finanças, v. 20, n. 49, p. 109125, 2009. Disponível em: <http://www.revistas.usp.br/rcf/article/view/34285/37017>. Acesso em: 21 maio 2017.

PORTER, M. Competitive Advantage: Creating and Sustaining Superior Performance. New York: Free Press, 1985.

SCOTT, M.; BRUCE, R. Five Stages of Growth in Small Business. Long Range Planning, v. 20, n. 3, pp. 45-52, 1987.

SEBRAE. Causa Mortis - O sucesso e o fracasso das empresas nos primeiros 5 anos de vida. São Paulo, 2014.

SEBRAE. Panorama das MPEs paulistas 2015. São Paulo, 2015.

SEBRAE. Participação das Micro e Pequenas Empresas na Economia Brasileira. São Paulo, 2014.

SEBRAE. Relatório Brasileiro do GEM - Global Entrepreneurship Monitor. São Paulo: Sebrae, 2008.

SEBRAE. Relatório Cenário das MPEs 2009-2015. São Paulo: Sebrae, 2008.

SCHEL, Jim. Guia para Gerenciar Pequenas Empresas: Como Fazer a Transição para uma Gestão Empreendedora. Rio de Janeiro: Campus, 1995.

SCHUMPETER, J. A. The theory of economic development. Cambridge, Massachusetts: Harvard University Press, 1934.

TACHIZAWA, T.; FARIA, M. Criação de Novos Negócios: Gestão de micro e pequenas empresas. Rio de Janeiro: FGV, 2007.

TERENCE, A. C. F. Processo de Criação de Estratégias em Pequenas Empresas: Elaboração de um Mapa Estratégico para Empresas de Base Tecnológica do Polo de São Carlos/Sp. São Carlos: USP, 2008.

THE WORLD BANK GROUP. Doing Business 2016. Washington DC: 2016. 
THIOLlENT, M. Metodologia da Pesquisa-ação. 14a ed. São Paulo: Cortes, 2005.

TIMMONS, J.; SPINELLI, S. New venture creation, entrepreuneurship for the 21st century. Califórnia: Irwin, 2004.

TREACY, M.; WIERSEMA, F. Customer Intimacy and Other Value Disciplines. Harvard Business Review, January-February 1993.

VERGARA, S. Métodos de coleta de dados no campo. São Paulo: Atlas, 2009.

WALlimAN, N. Métodos de pesquisa. São Paulo: Saraiva, 2015.

WEISS, A. Getting Started in Consulting. Third Edition. New Jersey: Wiley, 2009.

YIN, R. Estudo de Caso: Planejamento e Métodos. Porto Alegre: Bookman, 2015.

ZOOK, C; Allen, J. O Poder dos Modelos Replicáveis. Rio de Janeiro: Editora Elsevier, 2012. 